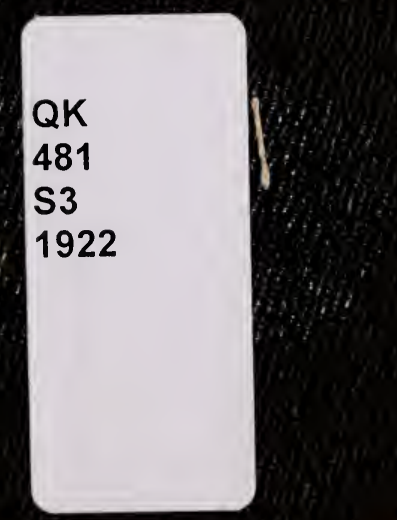


THE NORTH CAROLINA STATE COLLEGE D.H.HFLL LIBRARY)

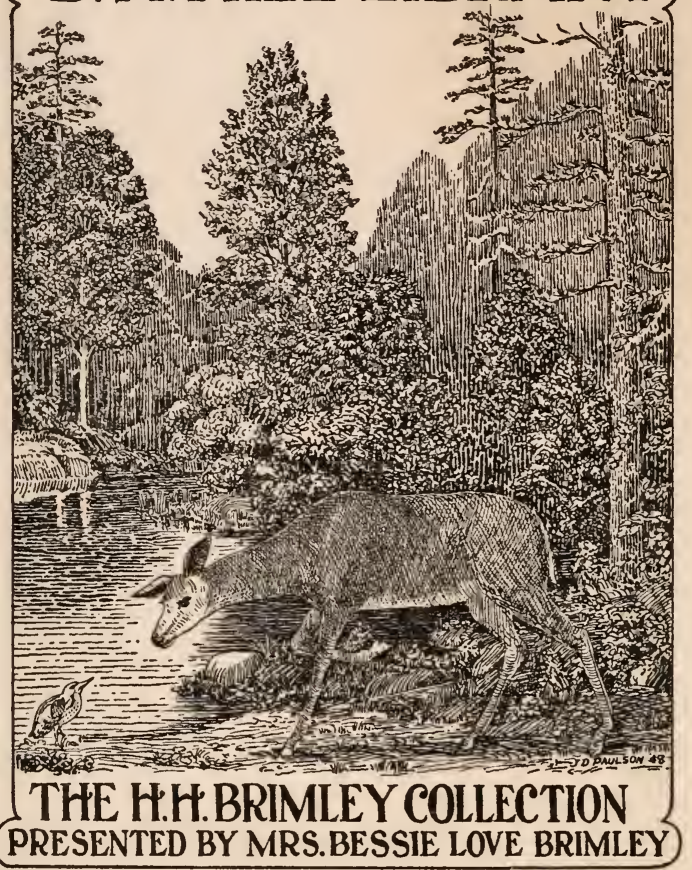

NORTH CAROLINA STATE UNIVERSITY LIBRARIES

||||||||||||||||||||||||||||||||| S02326931 Q 


\section{FIELD MANUAL of TREES}

\section{Including Southern Canada and the Northern}

Units

of This book is due on the date indicated unless recalled by the Libraries. Books not returned on time are subject to replacement charges. Borrowers may access their library accounts at: http://www.lib.ncsu.edu/ads/borrow.html 
COPYRIGHT, 1922

B Y

JOHN H. SCHAFFNER 


\section{PREFACE.}

This little manual represents a revision of the author's former "Trees of Ohio and Surrounding Territory," and attempts to carry out more definitely the idea of having a convenient guide by which it is possible to study our trees at any season of the year. The keys have been made very complete so that no difficulty should be encountered in identification except in the case of closely related species. No elaborate technical descriptions have been given but a few brief notes are added in connection with each species, calling attention to economic, ecological, or other data of general interest. Characters given in the keys are usually not repeated in the descriptions. A definite characterization is also given for each genus. This will be found to hold for all the species occurring in our region and in most cases for all the species of the genus.

The nomenclature used is essentially that of Britton and Brown's "Illustrated Flora of the Northern United States, Canada and the British Possessions." 2nd Edition, 1913. A rather conservative position has been taken in the treatment of species, since many of the forms recently described are regarded as merely elementary varieties either Mendelian or ecological. A single English name is given for each species. These names have been taken mainly from Sudworth's "Check List of the Forest Trees of the United States," which on the whole seems to be a very satisfactory basis for an appropriate list. Synonyms will be found in the index.

Most of our common, cultivated, exotic trees have been included, since these form an integral part of the landscape. in many places more conspicuous than the native species.

The study of trees may be made a pleasant and profitable pastime at any season of the year for all who have an interest in nature. When the tree has once been identified its peculiarities should be learned hy direct observation yntil its 
individuality becomes perfectly familiar. In winter one can usually find dry leaves or fruit on the trees, which will make it possible to tell most of the species at a time when many think botanical study out of season.

In this second edition, a few typographical errors have been corrected and a few slight changes have been made, but the Manual remains essentially the same as the first edition published in 1914.

J. H. S. 


\section{INTRODUCTION.}

A tree may be defined as - a woody plant of any size which produces naturally one main, erect stem with a definite crown of branches. A shrub is a woody plant which produces small irregular or slanting stems usually in tufts. In attempting to separate "trees" from the larger "shrubs," one must necessarily be somewhat arbitrary as nature draws no defirite division line. There are also trees which have no crown of branches, like the palms.

A tree has three main parts, the root system, the stem or trunk, and the crown of branches. The root system is for stipport in the soil and for taking up water and various mineral substances.- This is accomplished very largely by delicate organs called root hairs developed near the root tips. The root hairs are temporary structures developed from the epidermis of the root (piliferous layer) near the tip and dying off at the back as the root grows. Although largely dependent on their environment the roots still have considerable selective power in taking up the salts dissolved in the soil water. The root system may have a main or tap-root extending deep into the ground with smaller lateral roots; or the tap-root may be only slightly developed or entirely absent, in which case a number of larger branch roots may extend downward from the base of the trunk. The roots which extend laterally near the surface sometimes run to a great distance. Such roots are called tracing roots.

The trunk or bole is a supporting and conducting organ. The water with dissolved mineral sibstances taken up by the roots passes up through the young wood or xylem while the food material from the young twigs and leares passes up or down through the phloem cells of the inner bark. There are no real vessels for carrying food and water like the blood vessels of animals, but the sap passes through by osmosis from one cell to another or from one set of cells to another as it frequently happens when some of the cross walls are broken down in a vertical series of cells. The large cells in

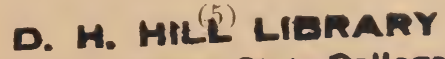 North Carolina State College}


the wood, however, are called rood ressels. Just how the water is able to pass up to the tops of high trees is not fully muclerstood. In early spring, as in the sugar maple, the water accumulates in the sap wood since there are no leaves from which it can be thrown off above.

The crown is a system of branches on which the leaves are developed and exposed to the light. In the leaves most of the food is manufactured which the tree uses for it: growth and nourishment. This production of organic food is carried on through the agency of sunlight and chlorophyll. as the green coloring matter is called. Another impertant function of the leaves is the transpiration of the surplus water brought up from below. The water transpired by a large tree in a single day is often very great in amount. The leaves are also important breathing organs, although not exclusively so: for all the living cells in the entire plant carry on the process of respiration.

The system of branching in the crown may be of various types. If the main trunk of a tree extends npward through the crown to the tip it is said to be excurrent, as in the larch and Austrian pine. When the terminal bud has no preeminence over others and the main trunk is soon lost, the tree is round-topped or spreading and is said to be deliquescent, as in the apple. Excurrent trees are often spire-shaped like the Norway spruce; while deliquescent stems commonly give rise to dome-shaped crowns, as in the white clm. If the terminal bud withers or is self-pruned, as in the linden, the branching is sympodial. If the leaves are opposite and the two lateral end buds devclop, the terminal bud being selfprumed.. the result is a sympodial dichotomy, as in the bladdernut. Trees in which the terminal buds are persistent and functional are said to have a monopodial system of branching.

The trunk or any branch of a coniferous or dicotylums tree consists of four main parts, the pith, the wood, the cambium or growing layer, and the bark. The wood consists of a series of annual rings, since if normal growth takes place cnly a single ring is produced each year. Each ring usually consists of two layers called early wood and late 1 ood. During special seasons or if growth is checked at times during the growing period more than one ring may be produced. although this in never perfect and van nowally be 
detected by careful examination. In most trees the inner part of the woorl and the pith are dead and this is called the heart wood or duramen, while the outer wood is lighter in color with living cells next the cambium layer, and is called the sap-wood or alburnum. Sometimes there is a striking difference in the color of the two parts. Strands of cells pass from the pith or annual rings through the wood to the loark. These are called medullary rays. The peculiar qualities of wood are due to the character of its cells which have their walls lignified or thickened by a leposit of a chemical substance called lignin.

The bark nsually consists of two main layers called inner hark and outer bark. The inner hark is often in very thin layers and is hence called liber. The onter luark is very diverse in character. Usually it consists mainly of layers of cork cells which are very impervious to water. Since the wuter bark wsually does not increase in diameter as rapidly as the wood it is finally torn into strips and peels off on the otitside. Trees have many interesting ways of developing and getting rid of their outer bark.

More commonly the outer bark is developed as follows: In a young main stem or twig there is a tissue between the outer layer of cells or epidermis andthe circle of vascular bundles which is called the cortex. While the stem is developing and hardening, the outermost layer of cortical cells just below the epiclermis is modified and begins to grow. This layer is the cork cambium or phellogen. The layer of tissue thus formed by the repeated divisions of the cells of the phellogen is called the periderm or cork. On the inner side of the phellogen another layer of tissue is produced which is called the phelloderm or secondary cortex. The phellogen may continue to produce periderm until the outer bark hecomes rery thick: and finally new cork cambiums may develop farther in in the cortex or even in the phlocm of the inner hark. In some plants the cork cambium originates from the cpidermis and in some from the deper layers of the cortex.

Some trees liave no special means of shedding their leaves while others shed them only after a year or more. Ilost of our indigenous species are "deciduous," that is they cast their leaves at the encl of each growing season by the formation 
of a cleavage plane or separation layer through the base of the petiole. They also prepare for winter by developing elaborate winter buds. The function of the winter buds is mainly to check evaporation from the delicate stem tips during the periods of freezing and thawing.

Many of the smaller branches and twigs of a tree especially when growing in a dense forest are continually dying off. But the tree rick itself of these dead branches by forming a collar of tissue from the cambium layer around the base of the dead branch. Which finally covers over the wound when the dead member falls off. This process is known as natural pruning. By the formation of a similar callus other wounds are covered i:p. There is still a more remarkable process present in many trees by which surplus living branches are cut off in one way or another. Terminal and lateral buds are also commonly cut off. This process of abscission is known as self-pruning. The most common method is by the formation of a cleavage plane in a basal joint or in the annual nodes of growth. In some genera brittle zones are produced. The self-pruning process is very highly dereloped in the cottonwood, white oak, white elm, and silver maple.

Trees grow in height only at the tips of the main stem (1) branches. Some trees are naturally shortlived; others attain an enormons size and age, hut from the very nature of their upright development their life must sooner or later come to an end. In some cases the individual organism may continue by a new development from spronts growing out of the stmimp or the roots.

All of our trees bear flowers and seeds. After arriving at a certain age dependng on the species, the tips of some twigs or the axillary buds will develop flowers. In the more bighly developed and typical flowers four sets of organs are present; the calyx composed of sepals, the corolla composed of petals, the andrecium composed of stamens, and the gynecium composed of carpels. The two essential sets of organs in the flower are the stamens and the carpels. These may both be in the same flower, when the flower is said to be hisporangiate or in separate flowers, when the flower is monosporangiate. If the staminate and carpellate flowers are on one individual the plant is monecions, if on two distinct indi- 
viduals the plant is diecious. In this case the plants are spoken of as staminate trees and carpellate trees. The stamens produce microsporangia and the carpels megasporan ia or ovules. In the anthophyta the carpel usually has three parts called stigma, style, and ovulary, the ovules heing completcls inclosed in the ovulary. Commonly all the carpels of the gynecium are grown together and in such cases a compound ovulary is produced with one or more cavities.

Following a peculiar process known as the reduction division which takes place in the cells inside of the micrusporangium, a considerable number of microspores are developed, four. for each original cell. In nearly the same way, four megaspores, one of which survives, are ustrally. produced in each ovule. The flowers are thus modified sporebearing branches or shoots producing two kinds of nonsexual spores. The flowers are nonsexual organs and the tree itself is always a nonsexual plant called the sporophyte, although some of its parts may show sexual characters and dimorphicm. The microspores germinate and develop into the pollen grains and the megaspores into the so-called embryo sacs, or minute. parasitic, male and female gametophytes respectively, which are the real sexual generation. After pollination has taken place, which is simply the transfer of the pollen to the ovules or to the stigmas, a tube grows from the pollen grain into the cmbryo sac. The two sperm cells produced in the pollen grain or in the pollen tube pass down the tube and one tnites with the egg cell of the female gametophyte. This uni n of sperm and egg is called fertilization. The resulting cell which is the oospore germinates and gives rise to an embryo inside of the ovule, the whole finally constituting the body called the seed. In the anthophyta, endosperm is produced in the seerl hy the union of the second sperm with two cells from the female gametophyte. This embryo in the seed is the sporophyte and after sprouting develops into the tree. The seed is produced inside of or in connection with the modified carpels and other contiguous parts, the whole being called the fruit. The fruits of our trees are of many types usually with some adaptation for seed distribution, so that the seed with its little embryonic tree inside may he carried away from the parent plants to some other and perhaps more faverable enviromment. Here, if conditions are proper, it sprouts and 
legrins its life as an independent individual. The whole process of flower, seed, and fruit production is exceedingly complex and requires close study and observation if one would know the more obscurc activities going on during the life cycle of a tree. 


\section{KEY TO THE GENERA OF TREES IN THE SUMMER CONDITION.}

Based mainly on leaf and twig characters. The number following the generic name refers to the list number.

1. Foliage leaves with expanded blades, netted-veined. $x$.

1. Foliage leaves needle-shaped, narrowly linear, sul)ulate, or scale-like; conifers. 2.

1. Foliage leaves fan-shaped with dichotomous renation, a number on thick, wart-like, persistent dwarf branches. Ginkgo. (1).

.). With typical dwarf loranches, persistent for more than 1 year. :3.

.. With feather-like dwarf hranches, deciduous each year, the linear leaves spreading into ¿) ranks.

Taxodium. (ㄹ)

-. Withont dwarf branches. 4 .

$\therefore$ Dwarf branches small, self-pruned, with -, foliage leaves. Pinus. (T).

$\therefore$ Dwarf branches thick, wart-like, persistent, with numerous deciduous leaves. Larix. (i).

t. Leaf buds scaly; leaves scattered. i.

1. Leaf buds not scaly, naked: leaves opposite or whorled. $\bar{T}$.

$\therefore$ Leaf scar on a sterigma, the twigs covered with scales representing the leaf hases. if.

$\therefore$ Leaf scar on the hark: twigs without scales: leates Hat. Abies. (j).

i. Leaves flat, those on the upper sicle of the wig much shorter than the lateral ones: trees. Tsuga. (4).

i. Leaves more or less t-sided, spreading in all directions. Picea. (:i).

7. lioliage leaves small, scale-like, appressed, opposite 1-ranked, closely covering the twigs which are decidedly flattened and fan-like: leaves of two shapes. the dorsal and ventral broader and less acute than the lateral ones: scales of the carpellate conc ti-lu. not preltite. Thuja. (s). 
7. Loliage leaves small, scale-like, appressed, opposite, t-ranked, usually much elongated, on somewhat flattened branches; scales of the carpellate cone $t-t$, the two upper fertile, not peltate.

Libocedrus. (9).

7. Foliage leaves small, scale-like, appressed, opposite, 1-ranked, closely covering the slightly flattened twigs which are not very fan-like; leaves nearly or quite similar; scales of the carpellate cone peltate.

Chamaecyparis. (10).

i Foliage leares of two types, scale-like and subulate, opposite or in threes; the scale-like leaves t-ranked, appressed, causing the twigs to appear quadrangular, the subulate leaves spreading; one or both types of leaves on a plant; carpellate cone developing into a bluish-black, berry-like fruit.

Juniperus. (11).

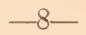

8. Leaves alternate. 9.

$\prec$ Leaves opposite or whorled. 74 .

9. Leaves simple. 10.

9. Leaves compound. 62.

10. Leaves pinnately veined or with a simple midrib. 11 .

11. Leaves palmately reined or at least with 2 or more prominent side ribs coming from near the base of the blade. 53 .

11. Leaves truncate or broadly emarginate; with complete stipular rings at the nodes. Liriodendron. (13).

11. Leares entire. 12 .

11. Leaves serrate, dentate, crenate, pinnatifid, or variously lobed. 25.

12. With stipular rings at each leaf node; leaves, large.

Magnolia. (12).

12. Not with stipular rings. 13.

13. With thorns and milky sap. 14 .

13. Without thorns: sap not milky. 15.

14. With thorns beside the axillary buds; leaves not tapering at the base, acute or even heart-shaped.

Toxylon. (52). 
14. With terminal thorns and some axillary thorns: leaves tapering to the base: narrow or slendercuneate. Bumelia. (69).

15. Leaves evergreen, coriacents, some on wood of the previous season. 16.

1.5. No leaves on wood of the previous season. 17 .

16. Leaves green on both sides, thick, coriaceous, oblong to oblanceolate, $5-10$ in. long; winter buds very scaly. Rhododendron. (66).

lit. Leaves green on both sides, or glaucous beneath, coriaceous, 2)-5 in. long; oval or oval-lanceolate. winter buds naked. Kalmia. (67).

16. Leaves bright green above, paler beneath, coriaceous, t-i in. long, pointed at both ends; bark aromatic.

Persea.

17. Pith with prominent diaphragms but solid; vascular bundles in base of petiole $3-7.18$.

17. Pith not both diaphragmed and solid, but sometimes with lenticular cavities. 19.

18. Leaves 2-ranked: bark with fetid odor: vascular bundles in base of petiole $5-7$. Asimina. (14).

1x. Leares not 2-ranked: vascular bundles in base of petiole 3. Nyssa. (81).

19. Leaves resin-dotted, waxy-dotted or punctate, oblonglanceolate, spatulate, or oblanceolate, short-pointed. narrowed at the base. Myrica. (63).

19. Leaves not dotted nor punctate, 20.

20. Pith prominently 5-angled; leaves with deciduous stipules and with bristle tips. Quercus. (56).

20. Pith cylindrical or nearly so; leaves not bristletipped. 21.

21. Leaves with the upper 2 lateral veins more or less parallel with the midrib. Cornus. (79).

21. Leaves pinnately veined to the tip. 22.

2.2. Bundle scar central; pith sometimes diaphragmed with lenticular cavities. $2:$.

2.). Bundle sears 2 or more: pith without lenticular cavities, 24 . 
2.:. Leaves truncate or short-pointed at the base, usually widest below the middle or somewhat oblong. glabrous when mature; fruit a large pulpy berry. very astringent when green. Diospyros. (70).

2:). Leaves pointed at the base, widest above the middle, lower surface pubescent; fruit a nut-like drupe.

Symplocos. (71).

-4. With prominent deciduous stipules; bark not resinous. Cydonia. (?t).

24. Without stipules; bark resinous, aromatic.

Cotinus. (14).

2.). Lateral veins from the midrib straight and parallel or nearly so; some or all lateral veins usually ending in the serrations, teeth or lobes. 26.

2.). Lateral veins not straight and parallel. 37.

26. Leaves not 2-ranked. 27 .

26. Leaves quite regularly -ranked, that is with the third leaf over the first. 30 .

27. Pith :3-angled, buds stalked. Alnus. (60).

27. Pith 5-angled, buds not stalked. ㄹ․

27. Pith cylindrical or nearly so. 29.

2R. Leaves or their lobes bristle-tipped, or if not bristletipped then the teeth or lobes not sharply acuminate; buds clustered at the tip of the twig; nut in a cup-like involucre of numerous scales.

Quercus. (56).

2x. Leaves with sharply acuminate teeth; buds not clustered at the tip; nuts with a prickly or spiny involucre. Castanea. (5i).

29. Usually with prominent and typical lateral thorns: carpels of the pome bony. Crataegus. (26).

29. Without thorns but sometimes with thorn-like stunted branches: leaves irregularly dentate, serrate or crenate-dentate; sometimes lobed: pome fleshy without grit cells; carpels papery or leathery.

Malus. (23).

29. Without thorns: leaves serrate or serrate-dentate: pome berry-like, carpels not bony. 
30. Leaves decidedly ine(puilateral at the base. 31

30. Leaves not ine(puilateral or only very slightly so. :3.

:3. Axillary buds prominently stalked; leaves repand dentate. Hamamelis. (fi).

31. Buds sessile: leaves doubly serrate, bath unt scaling off in plates. Ulmus. (

:3. Buds sessile: leaves serate, bark scaling off in plates like in the Sycamore. Planera. (19).

:32. Lateral veins ending in the large dentations or serrations which are always simple (a vein for each). 33.3.

:3.). Leaves doubly serrate or sometimes simply serrate. the lateral veins ending in the main serrations or teeth but not in the smaller ones, or the veins not ending in the serrations. : it.

:3:). Leaves orate or ovate-oblong. short acuminate: teeth net with slender points: bark smooth, light gray

Fagus. (.54)

:3:). Leaves oblong-lanceolate, acuminate, with slender often inwardly curved points on the serrations: bark rough. Castanea. (ii).

34. Lateral veins not ending in the serrations or teeth

Amelanchier. (20).

34. Lateral veins ending in some of the serrations, teeth or lobes.

3i. Bark smooth, the trunk and larger branches with fluted or projecting ridges; leaves acute or acuminate. sharply doubly serrate; nuts small, in a largebracted catkin. Carpinus. (.ii).

:i. Trunk and larger branches not with Huted or pro:ecting ridges. : $3 t i$.

31i. liark of trunk and larger branches separating inte papery or leathery sheets: trees or shrubs with glabrous, pubesecut, or glandular warty twigs.

Betula. (59)

36. Bark of trunk scily, finc furrowed; twigs glandularbristly; carpellate catkin in fruit appearing like that of the hopl. Ostrya. (is).

36. Bark sealing off in plates like in the Sycamore: fruit coriacenus, 1111-like. Planera. (19). 
37. Leaves 2-ranked. 38.

37. Leaves not 2-ranked. 39.

38 . Bark of trunk and larger branches separating into papery or leathery sheets: leaves doubly serrate, the lateral veins ending in the main serrations, teeth or lobes. Betula. (59).

38. Bark not in papery or leathery sheets; leares not doubly serrate, the lateral veins not ending directly in the serrations or teeth. Amelanchier. (25).

39. Leaves not with spines. 40.

39. Leaves evergreen, with spine-tipped lobes. Ilex. (36).

41. Pith not solid, diaphragmed, with lenticular cavities. 41.

41. Pith solid but with prominent diaphragms; vascular bundles 3 in the base of the petiole. Nyssa. (81).

41. Pith solid, without diaphragms. 42.

41. Leaves oval or obovate, serrate or denticulate, abruptly acuminate, wedge-shaped at the base, more or less stellate pubescent beneath; bark of twigs peeling off in slender shreds; fruit 4-winged.

Halesia.

41. Leaves oblong or slightly obovate, acute or acuminate at both ends, crenate-serrate or repand, short petioled; twigs of the season and lower surface of leaves pubescent, not stellate; fruit a nut-like drupe.

Symplocos. (71).

4.2. Leaves with peltate scales, or resin-dotted, oblanceolate or wedge-lanceolate. Myrica. (63).

12. Leaves not peltate scaly, nor resin-dotted. 43.

43. Outer bud scales of winter buds more than 1. 4 .

4:. Outer bud scale 1; twigs with brittle zones, hence easily detached and leaving peculiar self-pruning scars; terminal bud of ripe branches absent; bundle scars or vascular bundles in base of petiole. 3 .

Salix. (65).

14. Pith decidedly 5-angled. 45.

44. Pith cylindrical or nearly so. 46 .

4.5. Bundle scars 3 ; leaves with gland-tipped teeth, usually broad-based, usually with 2 prominent glands at the base of the blade. Populus. (64). 
4.). Bundle scars several, seattered; leaves without glands; buds clustered at the tip of the twig.

Quercus. (5if).

4i. With stipules or stipular scars. 47.

fli. Without stipules or stipular scars; leaves sour, with prominent scattered hairs on the midrib beneath; fruit a capsule. Oxydendrum. (68).

47. With typical lateral thorns: fruit a drupe-like pone with bony ripe carpels. Crataegus. (우).

47. Not with typical lateral thorus, but some may have thorn-like stunted branches. 4 s.

IN. Leaves with 1 or more dise-like, wart-like, or toothlike glands on the petiole or at the base of the blade. 49 .

fi. Leaves not with distinct glands on the top of the petiole nor at the base of the blade, but they may be glandular-hairy. jo.

4!). Twigs green, red, or red and green: nectar glands disc-like, usually $2-4$ near the base at the edge of the blade; terminal bud present; fruit a velvety drupe. Amygdalus. (로).

1!. Glands various; twigs not red and green, some with cleavage planes in basal joints; terminal bud present or absent, fruit a smooth drupe. Prunus. (27).

i). Axillary buds usually superposed; leaves lanceolate or oblong-lanceolate, tapering towards the short petiole; fruit a berry-like drupe. Ilex. (36).

i1). Ixillary buds not superposed. 51 .

i1. I.eaves with gland-tipped serrations; terminal bud absent on ripe twigs or if present then the lateral veins prominent and nearly parallel and curving upward at the margin of the leaf: fruit a herry-like Arupe. Rhamnus. $(: 34)$

$\therefore$ l. Laves not with gland-tipped serrations, or if so then not as above; terminal bud present; fruit a pome. .2.

i.). Leaves sharply and regularly serrate, glabrous when mature, petioles Inng: pome with grit cells.

Pyrus. (22).

$\therefore$.). Leaves irregularly dentate or serrate, or more or lesis Inbed: pome without grit cells. Malus. (2)3). 
ii. Base of petiole covering the axillary bud: twigs with stipular rings. Platanus. (4T).

ii. Axillary huds usually evident: twigs without stipular rings. it.

it. Leaves -ranked. j.).

it. I,eaves not -ranked. (il).

i.). Leaves entire, round-heart-shaped. Cercis. (29).

i.). Leaves serrate, dentate, or lobed. 56.

ili. Pith nsually in transverse plates: leaves ovate-lanceolate, inequilateral, taper-pointed. Celtis. (so).

iti. Pith solid, not diapluragmed. it.

it. With milky sap. is.

ii. Without milky sap. jy.

ix. 'Twigs gray or brown, glabrons or nearly so; leaves pubescent or glabrous beneath. Morus. (.)1).

ix. Twigs grayish-green, downy; leaves tomentose beneath. Papyrius. (5:3).

i9. Leaves not ine(unilateral; vascular bundles in base of petiole 3. Betula. (.99).

.)!. Leares inequilateral at the base: vascular bundles in base of petiole several, scattered. Tilia. (20).

(i). Leaves more or less star-shaped, with 3-7 long pointed serrate lobes, strongly aromatic when crushed; pith i-angled. Liquidambar. (46).

(ii). Leaves entire or three-lobed, bark spicy-aromatic; internodes very uneyual. Sassafras. (16).

lil. Leaves crenate, serrate, dentate, or lobed, not starshaped and not spicy-aromatic. (il.

(i). Pith i-angled: trees nsually with resinous buds: leaves ntsually broal based. Populus. (6t).

161. Pith cylindrical or nearly so; nstally with prominent typical thorns. Crataegeus. (־6).

62. Pith diaphragmed, with cavities; large trees with pinnate leaves. Juglans. (62).

(i). Pith not diaphragmed. 6;3.

ค.. Leaves trifnliate, odd-pinnate or odd-bipinnate. 64. 
(ii). Leaves evenly pinnate or hipinnate: axillary hudsuperposed. $7: 3$.

(i.). Lobes or teeth at the base of the leaflets with prominent green glands bencath; leaves pinnate, very large with disagreeable odor. Ailanthus. (1!)).

(it. I,obes or teeth if present without green glands. (i.). (i.). Leaflets glandular punctate; pith not i-angled: small trees or shrubs. li(j.

(i.). I,caflets not punctate. 67 .

lii. I.eaves pinnate, with stipular spines.

Zanthoxylum. (17).

liti. Leaves trifuliate, without stipular spines: bark with disagrceable odor: axillary buds superposed. cor(red by the petiole base. Ptelea. (1).

lii. Base of petiole covering the axillary buds, or if not. the petioles and stems prickly: some times with stipular spines. lis.

lit. Base of petiole not covering the axillary bucls: not spiny or prickly. Tu.

(iv. Leaflets entirc. 6!!).

(iv. Leaflets serrate or dentate, simply pinnate: pith very large: bark resinous or milky. Rhus. (fi).

fir. l,eares serrate; hipinnate, petioles and stems prickly.

Aralia. (

69. Leaflets mucrouate, usually obtuse; with stipular spines: base of petiole solid. Robinia. (:3:3).

(i.). I.eatlets abruptly acute: without stipular spines: base of petiole covering the buds like a cap.

Cladrastis. (:30) $)$.

71). I.eaflets cintire or if occasionally few-tonthed then the rachis promincently winged. 71 .

iII. I, eatlets serrate, dentate, or lobed, the rachis not winged. 7.2 .

71. Leaflets decidedly incyuilateral, obliquely lanceolate or falcate, acuminate. Sapindus. (38).

71. Leaflets not inefuilateral or only slightly so, $110 t$ -lender falcate, the rachis winged: twigs pubescent.

Rhus. (12).

71. I.eaflets not ine(puilateral or (m)ly slightly so) nent slender falcate; rachis not winged; twigs glabrous. 
7.). Pith i-angled; stipules nune, base of petiole with numerous vaseular bundles, scattered or in 3 areas.

Hicoria. (61).

i.). Pith not J-angled; stipules none; leatlets more or less lobed; vascular bundles in base of petiole scattered; terminal bud absent. Koelreuteria. (39).

i.). Pith eylindrical or nearly so; leaves with stipules; vasenlar bundles in base of petiole $3-\dot{\tau}$. Sorbus. (21).

7:3. Pith small; base of petiole covering the axillary buds: usually with prominent thorns. Gleditsia. (30).

7:P. Pith very large, lase of petiole not covering the axillary buds; without thorns. Gymnocladus. (31)

74. Leaves simple. TR.

74. I.eaves compound. 7 .

7.). Leaves digitate with is or more leaflets. Aesculus. (40)

7.5. Leaves trifoliate or pinnate. 76 .

7i. Base of petiole covering the axillary buds; leaflet dentate, lobed, or nearly entire. Acer. (41).

76. Base of petiole not covering the axillary buds. 77.

ii. Leaves trifoliate; bark with strong odor; terminal bud self-pruned. Staphylea. (3i).

77. Leaflets $5-13$; terminal bud present. Fraxinus. (74).

ix. Leaves pinnately veined. 82.

7R. Leaves palmately veined or at least with 2 prominent side ribs from the base. 79.

7!. Leaves entire or if somewhat :3-lobed with entire margin. 8i).

7!). Leaves serrate, crenate, dentate or varionsly lobed. 81.

kII. Pith diaphragmed, or with large cavities; petioles usually hollow; axillary buds superposed.

Paulownia. (76).

80. Pith and petioles solid; axillary buds not superposed; under side of leaves with glands in the axils of the larger veins. Catalpa. (77).

২1. Leaves more or less lobed; fruit a 2-winged samara.

Acer. (41).

81. Leaves not lobed; fruit a drupe. Rhamnus. (34).

\&. Leaves serrate, dentate, crenate, or varionsly lobed. 83. 
x.2. I.eaves centire. si.

x:?. Bark of ripe twigs green, bumblle scar or vascular bundle in hase of petiole 1 ; pith rlonbic.

Euonymus. (3ij).

3:3. liark of ripe twigs gray, brown, or red; pitli cylindrical or nearly so. 84.

24. Axillary buds sometimes superposed; leaves fincly denticulate: twigs light lorown, sometimes thorny: drupe narrowly oblong. Forestiera. (7\%).

s4. Ixillary buds not superposed; twigs not t-angled, brown: Howers epigynous: fruit a Heshy drupe: vascular bunclles in the base of the petiole:?.

Viburnum. (8:3)

s4. Axillary buds not superposecl; leaves serrate with stiptules, small; bundle scar central; twigs brown, sometimes with thorns: slirub-like trees with (lrupe-like berries. Rhamnus. (:;4).

$\therefore$ Leaves coriaceous, evergreen, hence on wood of the previous season. Kalmia. (67).

$\therefore$ Leaves deciduous each year. sti.

si. Leaves with the two outer lateral veins more or less parallel with the miclrib. St.

s6. Loaves pinnately veined to the tip. is.

57. Axillary buds not covered by the petiole base: intlorescence cymose. Cornus. (79).

57. Axillary buds minute, hidelen by the petiole base: Howers in involucrate leads. Cynoxylon. (si).

रू. Stiptules none: fruit an (1)blone drupe.

Chionanthus. $(7: 3)$.

85. Stipules present: fruit dry, in a head.

Cephalanthus. (\&.) ). 


\section{KEY TO THE GENERA OF TREES IN THE WINTER CONDITION.}

liased mainly on twig and stem characters. The number following the generic name refers to the list number.

1. Foliage leaves persistent and ustally evergreen.

1. Foliage leaves deciduous each year. 11.

.. Foliage leaves needle-shaped, subulate, narrowly linear, or scale-like: conifers. :3.

2. Foliage leaves with expanded blades, netted reined. *.

$\therefore$ With dwarf branches, each bearing -2) foliage leaves.

Pinus. ( 7 ).

$\therefore$ Without true dwarf branches. 4 .

4. Leaf buds scaly. i.

1. Leaf buds not sealy, naked. †.

$\therefore$ Leaf scar not on a sterigma, prominent. circular: leaves tlat. Abies. (5).

$\therefore$ Leaf sear on a sterigma, the base of the leaf remaining as a scale on the twig. fi.

i. Leaves flat, those on the upper sicle of the twig much shorter than the lateral ones. Tsuga. (1).

i. Leaves more or less t-sided, spreading in all clirections. Picea. (:3).

7. Foliage leaves small, scale-like, appressed, upposite, Iranked, closely covering the twigs which are decidedly flattened and fan-like: leaves of two shapes. the dorsal and ventral broader and less acute than the lateral ones; scales of the carpellate cone not peltate. Thuja. (R).

7. Foliage leaves small, scale-like, appresised, opposite, 1-ranked, usually much elongated, on somewhat Hattened branches: scales of the carpellate cone t-ti. the two upper fertile, not peltate. Libocedrus. (9).

7. Foliage leaves small, scale-like, appressed, opposite. t-ranked, closely covering the slightly Hattened twigs which are not very fan-like; leaves nearly or ytuite similar: scales of the carpellate cone peltate.

Chamaecyparis. (111). 


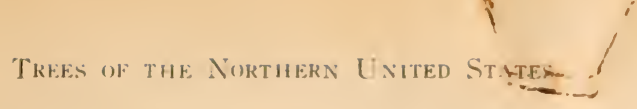

7. finliage leaves of two types, seale-like and sulumbute, opposite or in threes: the scale-like leaves 1-ranked. appressed. causing the twigs to appear quadrangular, the subulate leaves spreadings: one or both types of leaves on a plant: earpellate conc developing into a bluish-black, herry-like fruit.

Juniperus. (11).

$\therefore$ Leaves with spine-tipped lobes or teeth. Ilex. (36).

$\therefore$ Leaves without spines. 9.

!) Leares pubescent at least below, lanceolate, mucronate, not evergreen; buds clustered at the tip of the twig; trees with 5-angled pith. Quercus. (5i).

!) Leaves glabrous below; pith not i-angled. 10.

11. Leaves green on both sides, thick, coriacents, oblong to oblanceolate, fill in. long: winter buds very scaly. Rhododendron. (66).

11. Leaves green on both sides or glatucous beneath, coriaceons, - 2-j in. long, oval to oval-lanceolate: winter buds naked; erect shrubs. Kalmia. (6iT).

i1. Leaves bright green above, paler beneath, coriaceous, t-i in. long, pointed at both ends; bark aromatic.

Persea. (15).

11. Twigs with thick wart-like dwarf branches: gymnosperms. 12 .

11. Twigs without true dwari branches. 13.

1.. Yonug twigs covered with scales. Larix. (6i).

12. Twigs without scales. Ginkgo. (1).

1:3. Twigs with numerous small scattered self-prunimg scars. without apparent leat scars but with minute dry scale leaves, with feather-like dwarf branches. some nsually remaining in winter: foliage leaves -preading into two ranks; roots often with knees: a conifer. Taxodium. (丷)

13. Twigs with evident leaf scars and lateral winter buds. 14.

14. I.eaf scars alternate. 1\%.

14. Leaf scars opposite or whorled. i2.

1.). Twigs with distinct and complete stipular ridges or rings at the leaf nodes. Ifi. 
15. Twigs without complete stipular rings. 18.

1i. Leaf scar surrounding the axillary bud, terminal bud self-pruned: wood with prominent medullary rays.

Plantanus. (47).

11. Leat sear not surrounding the axillary bud, terminal bud not self-pruned; buds enclosed in the large connate stipules. 17.

17. Buds glabrous; twigs brown; pith diaphragmed; leaf scars oval or circular; bark spicy-aromatic.

\section{Liriodendron. (1:3).}

17. Luds downy, or if glabrous then the twigs red; pith with or without dlaphragms; leaf scars U-shaped. oval, or circular: bark usually aromatic.

Magnolia.

1s. With thorns, prickles, or spines; or with spur-like branches ending in thorns. 19 .

1ฬ. Without thurns, prickles or spines, but some may have thorn-like stmuted branches. 26 .

19. With stipular spines, a pair for each leaf scar. 2010.

19. Twigs with typical lateral thorns, without terminal thorns. 21.

19. With thorns at the ends of branches or with spur-like branches ending in thorns, and in addition axillary thorns may be present. 22.

1!). Stemn or twigs with prickles: leaf scar extending nearly around the stem, with about 20 bundle scars; pith large. Aralia. (78).

211. Leaf scar covering the two or more superposed axillary buds. Robinia. (33).

201. Leaf scar below the axillary buds; buds reddish, pubescent. Zanthoxylum. (17).

21. With thorns beside the axillary buds: normally one for each leaf axil, becoming gradually smaller toward the tip of the twig. terminal bud absent.

Toxylon. (52)

21. Thorns axillary, large, rarely branched except on the main trunk: usually with two lateral buds at the base which may develop as twigs; numerous axils without thorns. Crataegus. (26). 
21. Thurns commonly branched, situated above the axil of the leaf: leaf sear covering the two or more superposed axillary buds: twigs polished, often zigzag. Gleditsia. (30).

2.2. Not with three distinct bundle scars. 23.

2.). With three bundle scars. 24.

2:3. Puds and twigs glabrous or nearly so; with few thor1ls. Rhamnus. (3t).

2.: Buds and sometimes twigs pubescent or downy: thorns prominent. Bumelia. (6!)).

24. Terminal bud self-pruned; twigs some shate of black. brown, or reddish. Prunus. (27).

2. Terminal bud present. 25.

2.). Buds conical, pungent, pubescent, twigs glabrous or nearly so, mostly yellow-olive; trees with erect growth, the branches not spreading as in most of the apples. Pyrus. (22).

2). Buds downy or pubescent, twigs usually pubescent, if glabrous then dark reddish-brown; trees with rounded crowns and spreading branches.

Malus. (2:3).

26. I,eaf scars quite regularly 2-ranked, that is with the third scar over the first. 2 i.

26. Leaf scars not 2-ranked. 38 .

27. Bundle scar 1: visible bud scales 2): twigs brown: pith sometimes with cavities. Diospyros. (i0).

27. Bundle scars :3. 32.

27. Pundle sears more than 3 , nsually seattered. 20.

2.5. L'ith diaphragmed, solid; bundle sears j-7; bark with fetid odor; terminal bud elongated, naked, silky: itipular scar: none. Asimina. (1.t).

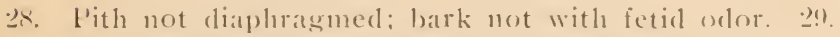
29. With very prominent medullary rays. 30.

29. Medullary raty inconspicuous. 31.

311. Winter buds usually Iong-puinted, with several tu numeroun dry scales. Fagus. (it).

311. Winter buds rather Heshy, unllally with 1-:3 visible scale's. Tilia. (29?).

\section{H. hILL lierary North Carollina State Colleze}


31. Hith s-angled, twigs glabrous or snmewhat pubescent, reddish or yellowish-brown. Castanea. (.)(0).

31. L'ith cylindrical; vinible bud scales more than 3 : twigs glabruts or pubescent but not downy.

Morus. (\$1).

31. Pitl cylindrical; visible bud scales 1-3, twigs downy, grayish-green, bark very fibrous. Papyrius. (5;).

:3.). Pith interruptedly diaphragned, with cavities, small. greenish-white. Celtis. (s)

:3.). l'ith solid. $3: 3$.

:i). Terminal bud naked, elongated, tomentose; budprominently stalked, light gray; twigs zigzag.

Hamamelis. (t.i).

:3). Terminal bud absent, the twig showing a terminal self-pruning scar at the morphological tip; or if present then with scales: buds not stalked. :34.

:4. Terminal bud present, long pointed; leaf scar narrow contracted hetween the bundle scars.

Amelanchier. (2,;).

:it. Terminal bud absent, or if present then the leaf sear oval or semicircular. $:$.

3.). Twigs dark reddish-brow1, speckled, often zigzag: buds reddish-violet, often superposed or clustered: leaf scars not oblique but below the lateral bud.

Cercis. (29)

35. Twigs dark brow11, not speckled: buds not superposed: leaf sears oblicute. 36 .

:36. Bark smooth, trunk and large branches with peculiar fluted or projecting ridges; bud seales brown. finely pubescent; staminate catkins in the but in winter. Carpinus. (5\%).

:iti. Trunk not with fluted or projecting ridges. 37 .

:3i. Rark of trunk scaling off like in the Sycamore: twigs very slender: 110 catkins. Planera. (4!).

: $:$. Bark in rough ridges; 110 catkins; twigs and buds in most cases pubescent: some species with characteristic transverse self-pruning scars on the twigs. others with corky ridges. Ulmus. (tR). 
:it. Bark scaly, line-furrowed, the furrows usually somewhat spiral: bud scales green with brown tips, nearly glabrons: twigs glandular-bristly; staminate catkins exposed in winter. Ostrya. (is).

:ii. liark of trunk and larger branclues separating into papery or leathery sheets; catkins in winter.

Betula. (5:9).

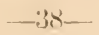

:3. With 르 or more superposed axillary buds: all except I maty be very small. 39.

in. Axillary buds single or "2 or more side by side: not superposed. 46.

39. Pith diaphragmed, with air cavities. I1!.

39. Pith diapluramed but solicl; bundle scars 3; stipular scars none. Nyssa. ( $\$ 1)$.

39. Pith not diaphragmed, solid. 11.

11. Pith large, brown: twigs thick, with large leat scarand 3 prominent bundle scars. Juglans. (62).

411. L'ith rather small, white or greenish; leaf scars semicircular; outer bud scales about @2. Halesia. (T.2).

11. Buds partly sunken, hardly projecting beyond the surface: terminal bud self-pruned or tips of branches withering. 1.2.

41. Musk not sunken in the epielermis. 4:3.

1.2. Leaf sear not surroundiug the axillary buds: pith large, chocolate-colored: twigs robust. polished. mottled white and purplish-brown.

Gymnocladus. (:31)

1.) Leai scat surroumbling the axillary husls, quadran sular L-shaped: bark with pungent odor: pith white. Ptelea. (KN).

1.. Leai -car covering the axillary buds; pith small; twigs brown, polished, wten zigzag. Gleditsia. (3010).

13. I'ith cylindrical or nearly so. H.

1:i. l'ith mure or less i-angled, yellowish or brownish: terminal bud large: bundle scars scattered; trees with fongls twigs. Hicoria. (til) 
14. Leaf scar surrounding the hairy axillary buds; bundle scars 5-9; terminal bud self-pruned.

- Cladrastis.

14. Leaf scar not surrounding the axillary buds. 45 .

45. Bundle scars 3; buds spherical, bark light gray; leaf scars heart-shaped; stipular scars none.

Sapindus. (38).

4.). Pundle scar usually 1; buds rounded or somewhat pointed; stipular scars or minute stipules present.

Ilex. (36).

46. Terminal and lateral buds stalked; pith 3 -angled; both staminate and carpellate catkins present all winter.

Alnus. $(60)$.

fi. Buds sessile or nearly so; pith not 3-angled. 47.

47. Leaf scars surrounding the axillary buds which are usually sunken: terminal bud self-pruned; bark resinous; pith large. Rhus. (42).

47. Leaf scars not surrounding the axillary buds. 48 .

is. Bundle sear 1, or if several then closely crowded and confluent, appearing as 1.49.

fi. Bundle scars more than 1. jt.

19. Stipular scars and stipules present. 50.

49. Stipular scars and stipules none. 51.

in. Terminal bud absent; bud scales dark brown or black. Rhamnus. (:3t).

in. Terminal bud present: stipules minute, usually persistent. Ilex. (36j).

il. Terminal bud present. i.

.i. Terminal bud absent. is.

i.). Pith diaphragmed, with cavities; bark reddish; onter bud scales several, short. Symplocos. (71).

.2. l'ith not diaphragmed; bark green, very spicy aromatic; internodes very unequal. Sassafras. (16).

ii. With polished, greenish-brown, grayish-yellow, or red twigs; bark sour; leaf scar prominent, semi-oval, with a dark central scar usually in the form of a ring; buds small, not projecting much beyond the epidermis: the large terminal panicled raceme with capsules persisting all winter. Oxydendrum. (68). 
i:3. With 2 visible sales in the triangular flattened bud: pith sometimes with cavities; twigs pubescent, zigzag at the tip. Diospyros. (70).

5t. Outer bud scales more than 1. j.

it. Outer bud scale 1; twigs usually with brittle zones and hence very easily detached; stipular scars present: bundle scars 3 ; pith small. Salix. (65).

i.). Pith diaphragmed but solid; bundle scars :3; 110 stipular scars. Nyssa. (81).

5.). Pith not diaphragmed. 56 .

56. Pith more or less 5-angled. 57.

56. Pith cylindrical or nearly so. 61.

57. Buds clustered at the tip of the twig; bundle scars numerous, scattered. Quercus. (56).

57. Buds not clustered at the tip. 58.

58. Bundle scars numerous usually scattered. 59.

58. Bundle scars 3. 60 .

59. Buds small with about 3 outer scales; twigs reddish or yellowish-brown, glabrous or pubescent; terminal bud present or absent; stipular scars prominent. Castanea. (5.5).

j9. Terminal bud large with 4 or more visible scales, hairy or peltate pubescent; lateral buds usually superposed; twigs tough. Hicoria. (61).

60. Without stipular or self-pruning scars; crushed buds fragrant, aromatic, not resinous, glabrous.

Liquidambar. (46).

60. Stipular and self-pruning scars present; crushed buds not fragrant though they ma have a resinous odor. resinous or if only slightly so then the twigs pubescent or tomentose. Populus. (61).

61. Pith very large, light brown, bark not resinous, illsmelling; buds spherical or flattened at the apex, often clustered at the tip of the twig. brown and pubescent; bundle scars about 9 along the lower edge of the very large leaf scar; large trees.

Ailanthus.

(i). Pith small, or if large and brown then the bark resinous. 62 
6i-2. Bark with a resinous or sticky milky sap; pith usually large, if rather small then the bark aromatic. 63.

(ii). Bark not resinous. (it.

6i:. Buds clustered at the tip of the twig; bark spicyfragrant to the smell; base of petiole prominent with several bundle scars; fruiting panicles plumose.

Cotinus. (44).

(ii.). Buds not clustered at the tip; bark often very poisonous to the touch; leaf scar partly surrounding the bud: small trees or slirubs. Toxicodendron. (43).

fit. Terminal bud absent. 6..

it. Terminal hud present. G\&.

(i.). Stipulen or stipular scars absent or indistinct. biti.

(i.). Stipules or stipular scars present. 67.

(iti. Buds clustered at the tip of the twig; young twigs glandular dotted. Myrica. (63).

(ifi. Buds not clustered at the tip: twigs not glandular: bundle scars 3 . Prunus. (2T).

bit. Buds not clustered at the tip; twigs not glandular: bundle scars numerous: outer bud scales :.

Koelreuteria.

(ii. Buds and twigs very downy, twigs dark brown or black. Cydonia. (24).

(ii. Ruds downy or pubescent: twigs glabrous or pubescent, gray or brown. Rhamnus. (34).

(is. Twigs green or yellowish-green, glabrous; internodes very unequal: lateral buds minute: small trees.

Cornus. (7!) .

dis. Twigs normally red above and green beneath. glabrous; bark very bitter: some axils with 2 or 3 hairy buds of nearly equal size: trees.

Amygdalus. (28).

(ir. Twigs not green or red and green unless the plants are low shrubs, but gray, brown, black, or reddish. $6 ?$ ?

(i). Pundle scars i or more in the broad U-shaped leaf scar; tips of the buds quite downy: small trees.

Sorbus. (21)

(ii). Bundle scars ?. TI.

i1. Burls rounded at the apex. often clustered at the tip of the twig: twigs glandular dntted. Myrica. (63). 
i11. Liuds romeled at the apex: scales thick: twigs often zigzag: plant usually with some thorns, not glandular dotted. Crataegus. (206).

il. Luds pointed: plants sometimes with thorn-like stunted branches, not glandular dotted. 71 .

71. Buds glabrous or slightly pubescent: twigs usually glabrous and slender, some shade of black, brown, or reddish, often with 2 or 3 axillary buds: some with self-pruning scars. Prunus. (27).

71. Bucls downy or strongly pubescent, conical, pungent: twigs glabrous, mostly yellow-olive; trees with erect growth, the branches not spreading as in most of the apples. Pyrus. (2)

71. Buds downy or strongly pubescent; twigs strongly pubescent or if glabrous then dark reddish-brown: trees with rounded or spreading crowns.

Malus. (2?)

71. Buds and twigs very pubescent; terminal bud with long spreading scales: shrubs or small trees with globose berry-like drupes containing 2-4 stones.

Rhamnus. (34)

i.). Bundle scars 1, or several closely united in a curved line, appearing as 1 . it.

72. Bundle scars more than 1 but not in an ellipse or ring. 78 .

i2. Bundle scars numerous, in an elipse or ring: buds small and tlat or superposed, pith large. 73.

73. Pith with cavities or more or less diaphragmed; axillary buds superposed. Paulownia. (T(i).

7:3. Pith solicl; axillary buds small and Hat, not superposed, leaf scars often in threes. Catalpa. (76).

71. Twigs very green, more or less 1-angled: pith diamond-shaped or rhomboidal. Euonymus. (3.j).

71. Twigs not green when ripe but gray, brown or red. sometimes 1-angled: pith cylindrical or nearly so. 7.).

i.) Terminal bud absent, the twig usually ending in a thorı. Rhamnus. (31).

ii. Terminal bud present unless the twig is fruiting. Ti. 
Tf. Ixillary huds often superposed: twigs often with lhurus; leat scars small. Forestiera. (75).

il. Ixillary buds not superposed: no thorns on the twigs: leaf scars rather large. 77.

TT. Twigs and buds pubescent; lateral buds cylindrical or hemispluerical: bud scales dry; leaf scar concave, on the short petiole base; lenticels large and conspicuous: fruit a drupe. Chionanthus. (73).

7. Buds rough or pubesceut; twigs glabrous or pubescent, sometimes t-angled; lateral buds somewhat tlattencel. obtuse: bud scales rather dry; leaf scar closé to the bark; lenticels not large; fruit a samara. Fraxinus. (74).

7. Axillary buds minute and sunken; twigs glabrous or pubescent; stipules dry, prominent; or with prominent stipular scars. Cephalanthus. (82).

ix. With 4 distinct stipular scars; terminal bud selfpruned: twigs green with strong odor.

Staphylea.

is. Without defnite stipular scars: twigs not green or if so then the terminal hud present. 79.

¡!!. Trees or shrubs with numerous bundle scars, sometimes in 3 areas, in a large heart-shaped leaf scar: pith rather large; terminal bud large, with numerous scales. Aesculus. (40).

7!). Bundle scars 3 or sometimes $\dot{y}$. 80 .

sil. Terminal bud with 2 long acmminate pubescent outer scales: line commecting the mppermost leaf scars notshed. \$1.

*i). Terminal bud with one main pair of risible scales and
a smaller pair at the base.
Viburnum. (8:3).

(ii. Terminal bud with several pairs of visible scales: bundle scars 3-5; twigs sometimes green.

Acer.

R1. Axillaty buds usually minute and mudeveloped except at the base of the peduncle which is selfpruned; twigs green or reddish-green, glabrous wr nearly so. Cynoxylon. (\$0).

x1. Axillary buds normally well developed and prominent: twigs often very puluescent. Cornus. (79). 


\section{GENERAL KEY TO THE FAMILIES AND GENERA.}

Based on the flower and other characters present at the time of blooming. The number following the generic name refers to the list number.

1. Ovules naked on an open carpel; pollen falling directly on the micropyle of the ovule which is without a pollen-chamber; trees or shrubs; ours usually evergreen with narrow leaves: monecious, rarely diecious. 2.

1. Ovules in a closed carpel or set of earpels provided with a stigma for the reception of the pollen; Howers more commonly showy. $t$.

2. Leaves fanshaped, dichotomously veined, on thick wart-like dwarf branches: diecious trees.

GINKGOACEAE.

\section{a. Ginkgo. (1).}

-. Leaves not fanshaped and dichotomously veined, but needle-shaped, narrowly linear, subulate or scalelike. 3.

$\therefore$ Leaf buds naked; carpels few, spiral; leaves on feather-like dwarf branches which are deciduous. T.IXONACE.AF.

\section{a. Taxodium. (2).}

$\therefore$ Leaf-buds naked; carpels few, opposite, sometimes forming a black or blue berry-like fruit; leaves opposite or whorled, rarely scattered, persistent JUNiperaceae.

a. Carpellate cones oblong, the scales not peltate. b.

a. Carpellate cones globose or nearly so, the scales peltate, or forming a bluish herry-like fruit. $c$

b. Cone scales (i-11, the 4 upper fertile. Thuja. (s)

b. Cone scales t-fi, the onper fertile.

Libocedrus.

c. Cone with rly peltate scales; ovules usually 2.

Chamaecyparis. (10). 
c. Cinc becoming blue and lleslyy; twigs not Hattened: leaves or some of them often subulate.

Juniperus. (11).

3. Leaf-buds scaly; carpels ustually numerous; leaves spirally arranged, the foliage leaves often situated on dwarf branclies. Pinaceaf.

a. Without dwarf branches. b.

a. With dwarf branches. d.

b. Leaf scar on a stcrigna, the twigs covered with scales representing the leaf bases. c.

b. Leaf scar on the bark: twigs without scales; leaves nsually flat: carpellate cones erect.

Abies. (5).

c. Leaves more or less 4-sided, spreading in all directions; carpellate cones pendulous. Picea. (3).

c. T.eaves flat, those on the upper side of the twig much shorter than the lateral ones: carpellate cones small, pendulons. Tsuga. (t).

(1. Leaves deciduous, numerous on thick, wart-like dwarf branches. Larix. (6).

d. Leaves needle-shaped, persistent, 2-7 on small self-pruned dwarf branches. Pinus. (7).

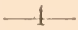

1. Leaves mostly parallel-reined, sometimes nettedveined; parts of the flower very often in threes (trimerous); cotyledon 1; the closed vascular bundles scattered through the pith, usually not in a circle; no annual rings of growth. No trees in our region. MONOCOTYLAE.

4. I.eaves usmally netted-reined; parts of the Hower more commonly in fives (pentamerous) or fours (tetramerous): cotyledons usually 2; vascular bundles usually in a circle around a central pith, forming annual rings of growth in perennial stems, with bark on the outside. i.. 


\section{DICOTYLAE.}

$\therefore$ Perinath none or of similar segments or divided into calyx and corolla; corolla when present choripetalous (petals distinct), sepals, petals and stamens sometimes on a disk or hypanthium. fo.

$\therefore$ Perimath composed of calyx and corolla, calyx may be minute or supprensed; corolla sympetalous (petals more or less molede. :39.

di. Calyx and corolla both present, calyx may be minute. i.

(i. Only the calyx present, sepals distinct or united, green or colored; or perianth none. 25.

7. Flowers hypogynous or perigynous; ovulary free or only slightly adherent to the perigynous disk or hypanthium. \&.

†. Flowers epigynons or apparently epigynous; calyx above the ovulary, with or without an hypanthium. 24.

$\therefore$ Stamens numerous, at least more than 10 and more than twice the petals. 9 .

$\therefore$ Stamens not more than twice as many as the petals, when of just the number as the petals then alternate with them. 12 .

8. Stamens of the same number as the petals and opposite them; ovulary 2-5-hocular, calyx 4 -5-cleft. valvate in the bud; petals involute; fruit a drupe or capsule; shrubs, small trees, or vines with simple leaves. RHAMNACEAL.

\section{a. Rhamnus. (34).}

6. Carpels 1 or more, united, but styles and stigman may be several. 10.

9. Carpels more than 1, district; filaments shorter than the anthers; perianth trimerous; leaves 2-ranked. ANoNACEAE.

\section{a. Asimina. (11).}

9. Carpels numerous spirally arranged and cohering over eacl other, forming an aggregate conc-like fruit; trees: sepals and petals in threes: twig-

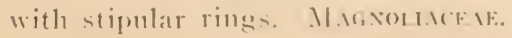


a. Anthers introrse; leaves nut truncate.

Magnolia. (12).

a. Anthers extrorse: leaves truncate.

Liriodendron. (13).

11. Ovulary compound, plurilocular. 11.

11. Ovulary unilocular, 2-ovuled; leaves usually with disklike or tooth-like glands on the petiole or at the base of the blade. Rosaceae. (Amygdalatae).

a. Young ovulary and drupe glabrous. Prunus. (27). a. Young ovulary and drupe velvety-pubescent.

Amygdalus. (28).

11. Flower cluster subtended by a large, membranous bract: calyx deciduous; leaves alternate, 2-ranked: sap) mucilaginous. Tiliaceae.

\section{a. Tilia. (20).}

i1. Flowers not subtended by a membranous bract: leaves alternate with deciduous stipules: sepals persistent. Rosaceaf. (MALAtaE).

See 24 below.

1.2. Ovulary only 1, carpels 1 to many, united. 1.).

12. Carpels 2 or more, distinct, or somewhat united at the base. 13 .

13. Leaves compound. 14 .

13. Shrubs or trees with alternate simple leaves. HAMAMELIDACEAE.

a. Ovules 1 in each cavity; leaves inequilateral, not star-shaped. Hamamelis. (45).

i. Ovules several in each cavity, fruit globular, spiny. Liquidambar. (46).

14. Leaves punctuate with pellucicl dots. alternate. Ritaceae.

\section{a. Zanthoxylum. (17).}

ii. Leaves large, pinnate, alternate, not punctuate but with disc-like glands under the teeth or lobes. SimaRL'BACE.AF.

\section{a. Ailanthus. (19).}

1.). Carpel 1. ovulary with 1 parietal placenta: leaves alternate, usnally with stipules, usually compound FARACFAF. 
A. Upper petal inclosed by the lateral ones in the bud; leaves simple or componnd mostly with stipules. Cassiatae.

a. Leaves simple, flowers bisporangiate.

Cercis. (29)

a. Leaves compound, thowers diecious or imperfectly diecious. b.

b. Stamens 3-5; pith small: usually with thorns. Gleditsia. (30).

b. Stamens 10: pith large, chocolate-colored: without thorns. Gymnocladus. (:31).

B. Upper petal inclosing the lateral ones in the bud: leaves compound (sometimes with 1 leaflet) with stipules. Faratae.

a. Without stipular spines: leaflets large, 3-6 in. long: base of petiole covering the axillary buds like a cap. Cladrastis. ( $(3-2)$.

a. With stipular spines: leaflets small, 1-2 in. long: base of petinle not covering the axillary buds like a cap, but solid.

Robinia.

(33)

1.). Carpels more than 1 as shown by the compound ovulary, carities, placentae, styles, or stigmas. 16.

16. Ovulary -locular to pluriocular. 17.

16. Ovulary 1-locular, ovules solitary, stigmas 3 ; shrubs or trees with resinous or milky sap and alternate leaves without stipules. AxAlARIACEAE.

a. Leaves compound: style terminal. b.

a. Leaves simple: style lateral. Cotinus. (14)

b. Petiole base covering the axillary buds, or if not then the rachis wing-margined: not poisonous.

Rhus. ( +. 2 ) ).

b. I'etiole base not completely covering the axillary buds, the rachis not wing-margined; poisonous to the touch: glabrous: leaslets entire.

\section{Toxicodendron. ( $(4: 3)$}

17. Flowers regular or nearly sol. 1s.

ii. linwers irregular: shrubs or trees with opposite

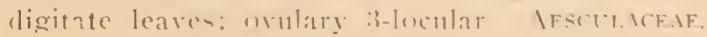




\section{a. Aesculus. (fi) ).}

17. Filowers irregular in the number of the sereral Horal sets: leaves pinnate or bipinnate, alternate: ovnlary 3-locular. SAPNDACEA.

\section{a. Koelreuteria. (:3!)}

Is. Stamens neither just as many nor twiee as many at the petals. 19.

15. Stamens just as many or twice as many an the petals. 20.

1!: Stanens distinct and fewer than the 4 petals; trees or shrubs with opposite pinnate or simple leares. Olenceaf.

a. Flowers diccious, from catkin-like scaly buds.

Forestiera. ( (

a. Flowers bisporangiate, petals linear.

Chionanthus. (73).

19. Stamens more numerous than the petals: leaves palmately veined, opposite; fruit 2-winged. Some Aceracene.

\section{a. Acer. (41).}

201. ()rules 1 or 2 in each cavity. 21.

201. Ovules several or many in each cavity; stipules between the opposite and pinnately compound leaves. caducous; shrubs or small trees. Staphvienceal.

\section{a. Staphylea. (37).}

21. Lealles palmately veined, or compound. 2-2.)

2 1. Leaves pinnately veined, simple, not punctuate. 2:3.

2.). Leaves pinnately compound, alternate: climbing herbaceous vines with fruit an inflated 3-lobed capsule; or trees with a globose or lobed berry. SAPINDACEAE.

\section{a Sapindus. (38)}

2.). Leaven palmately veined or pinnately compomme treen or shrubs with opposite leares and no stipules. ACRACFAF. 
a. Acer. (11).

2.). Leaves :i-foliate, pellucid-punctuate, withunt stipuleSome Rutaceal.

\section{a. Ptelea. (18).}

29. Callyx minute: trees or shrubs with simple mostly alternate leaves. II.ICACEAk.

a. Ilex. (36).

2:) Calyx not minute; trees, shrubs, or woody climbers ours with opposite leaves and with minute fugacerus stipules. Crlastraceat.

\section{a. Euonymus. (35).}

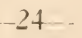

ㄴ. Perfect stamens 4, styles 2); leaves alternate, palmately veined-and lobed, or if pinnately veined then ?rankerl. HAMAMELIDACEAE.

See 1.3 above.

24. Stamens i, 10, or many: styles 2-5; leaves alternate with stipules. Rosaceae. (MAI.ATAE).

a. Leaves pinnate. Sorbus. (21).

a. Leaves simple. b. -

1). Cavitics of the ovulary as many as the styles. c.

1). Carities of the ovulary becoming twice as many as the styles. Amelanchier. (20i).

c. Ovules many in each cavity (carpel). Cydonia. (24).

c. Ovules 1-3 in eaclu cavity of the ovtulary. (l.

1. Usually with typical thorns: ripe carpels bony.

Crataegus. (우 $(i)$.

d. Without thorns, but some may have thorn-like stunted branclies: ripe carpels papery or leathery: e.

e. I caves sharply and regularly serrate, glabrous when mature, petioles lone: pome with grit cells. Pyrus. (22).

c. Leaves irregularly dentate or serrate. or more or less lobed; pome without grit cells. Malus. (23). 
24. Stamens + or 5, style and stigma 1: leavis npposite or alterliate. CORNickit.

a. Ovulary 2-locular, flowers bisporangiate. b.

a. Ovulary 1-lecular, flowers diecious or imperfectly diecions. Nyssa. ( $\$ 1)$.

b. Flower- eymose, not involucrate. Cornus. (79).

b. Flowers capitate, with an involucre of 4-6 large White bracts. Cynoxylon. (80).

24. Stanens 4 or ; on a flat disc which covers the 3-5locular ovulary; shrubs or trees with opposite leaves and minute fugaceous stipules. Celastracear.

See $2: 3$ above.

24. Stamens i, styles matly 2-j; leaves bipinnate. AR MLIACEAE.

a. Aralia. (78).

\section{$-25$}

2.5. Leaves opposite. 26 .

-5.) Leaves alternate. 27 .

-21i. Stamens i-x: leaves palmately veined and simple or if pinnately compound then the base of the petiole envering the axillary buds. Aceraceae.

\section{a. Acer. (41).}

21i. Stamenc 2-4; leaves pinnately veined when simple. or pinnately compound then the axillary buds exposed. Or.faceAt.

a. Flower- fateciculate or racemose-fascieulate, not from prominent sealy buds; leaves compound.

Fraxinus. (it).

a. Filowers facciculate, from scaly buds: leaves simple. Forestiera. (ii).

-2. It least the staminate llowers in catkins or catkinlike spikes or spherical beads. : 11.

2-. 131wer-not in catkin-or catkin-like spikes or heads. 2k. -s. With prominent itipular spines: leaves punctuate with glande. R1тACFAF.

a. Zanthoxylum. (17).

2x. Without stipular spines. -2!!. 
29. Styles or stignas 3 or 4 ; perigynoms stamens $4-5$, alternate with the sepals; ovulary -2-5-focular, ovule solitary in each carity. RHAMNACEA:

\section{a. Rhamnus. (3t).}

29. Styles or stigmas 2 ; leares 2 -ranked; orulary 1-2.ovuled; stipules fugaceuts. C'mackar.

a. Flowers in clusters on twigs of the previous seasol1, pith not diaphragmed. b.

a. Flowers on elongated twigs of the season; pith interruptedly diaphragmed. Celtis. (5) (1).

b. Flowers expanding before the leaves: bark in rough ridges. Ulmus. (48).

b. Flowers expanding with the leaven: bark of trumk scaling off like in the Sycamore. Planera. (4!).

29. Style and stigma 1. 30 .

31. Calyx 6-parted; stamens and staminodes about 1.2, in t series; bark spicy-aromatic. LALRACEAE.

a. Flowers bisporangiate, panicled; leaves evergreen. Persea. (1:i).

a. Flowers monosporangiate, racemose or umbellate; leaves decidnous, some of them lobed. Sassafras. (16i).

:31. Calyx i-parted: stamens 10 or fewer: bark not aromatic. FABACEAE. (CASSIATAE).

See 15 above.

311. Calyx i-parted: -tamens 5-15; flowers epigynous; pith solid hut diaphragmed. CORNACEAF.

\section{a. Nyssa. (ह') .}

31. Twigs with complete stipular rings; base of petiole covering the axillary bud; flowers monecions, in dense heads. PL.ITAXickal..

\section{a. Platanus. $(4 \bar{\tau})$.}

31. Twigs without stipular rings. 32.

32. Axillary buds superposed; staminate flowers in Hexible catkins: leaves pinnately compound.

a. Pith solid. Hicoria. (61).

a. I'ith diaphragmed, with cavitics. Juglans. (162). 
:i.2. Ixillary buds not superposed or if so then the staminate flowers not in flexible catkins: leaves sim ple. :3:?.

:3. Carpellate tlowers epigynous; pith solid, with diaphragms. CORNACEAE.

\section{a. Nyssa. (81).}

:3i. Carpellate flowers hypogynous or perigynums; pith not diaphragmed. :34.

:it. Staminate and carpellate flowers in densc spherical heads, sap not milky; leaves star-shaped, fragrant when crushed. HamaMELIDACE.AE.

\section{a. Liquidambar. (46).}

:34. Staminate and carpellate flowers not in dense spherical heads muless the sap is milky; leaves not starshaped. 35.

ai. With milky sap; leaves with two prominent lateral veins from the base or if not then the twigs thorny. MORACEAE.

a. Twigs with thorns; carpellate perianth deeply cleft, carpellate flowers capitate. Toxylon. (.i)). a. Twigs without thorns, b.

b. Staminate and carpellate flowers in ament-like spikes. Morus. (51).

1). Staminate flowers racemose or spikate, the carpellate capitate. Papyrius. (5i3).

$\therefore$ Sap not milky. 36 .

:it. Broth staminate and carpellate flowers in aments, the carpellate flowers not subtended by a bur or cup. :3T.

:36. (arpellate flowers not in aments, subtended by a cup or involucre; staminate flowers in Hexible or some. what capitate aments. Ficice.AE.

a. Staminate flowers capitate, ovulary :3-angled.

Fagus. (it).

a. Staminate flowers in slender aments. b.

b. Carpellate flowers 2-5 in each involucre, which becomes prickly. Castanea. (5.5).

b. Carpellate flower 1 in each involucre, which consist. of numerous scales. Quercus. (5ifi). 
:3-. Ovulary 1-locular, many seeded; seeds with a tuft of cottony hairs. Silicace.de.

a. Stamens numerous; bracts fimbriate or cutire, buds with several exposed scales: pith iangled. Populus. (64).

a. Stamens 2-10; bracts entire: buds with 1 outer scale. Salix. (65).

:3. Ovulary 1-2 Incular, with $1-2$ ovules in each cavity: seeds not with cottony hairs. 38.

:38. Carpellate Howers single in the axils of the bracts: ynung twigs and leaves glandular dotted; bud. clustered at the tip of the twig. MYRICACEAE.

\section{a. Myrica. (6.3),}

3. Carpellate flowers? or more in each bract of the ament: twigs and leaves not glandular dotted: buds not clustered at the tip of the twig. Betulaceat.

a. Pitlı :3-angled; buds stalked; leaves not 2-ranked: stamens 4. Alnus. (6it).

a. Pith not ?-angled; buds sessile; leaves 2-ranked. b.

b. Staminate flowers : $;-6$ in the axil of each bract. with a calyx; carpellate flowers without a calyx; stamens ?. Betula. (59).

b. Staminate flowers solitary in the axil of each bract, without a calyx: carpellate Hower with a calyx. c.

c. Fruiting bract flat, 3-cleft and incised: bark smonth; trunk and large branches with peculiar

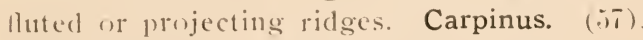

c. Jiniting bract bladder-like, closed: bark of older trunki sealy and line-furrowed. Ostrya. (is).

\section{$-39-$}

39. Flower- lypogynous (ovulary superior). ful.

:3!. lifowers epigyuous (ovulary inferior). H.

f1. Stamens free from the corolla (or only very slightly united at the base) as many as the petals (fowers tetracyclic) and alternate with them. or twice at many (pentacyclic) or more. 11.

10. Stamens united with the corollat, as many at the petals and upposite them or twice as many or more. 1: 
10. Stamen- united with the corolla, the fertile ones fewer than the petals and alternate with them. 43.

11. Sympetalous trees or shrubs often with evergreen leaves without stipules. ERICACEAE.

a. Leaves deciduons in autumm: Howers in panicled racemes: leaves sour, with long bristles on the midrib beneath. Oxydendrum. (68).

a. Leaves evergreen, coriaceous. b.

b. Corolla somewhat irregular, campanulate, without little sacs. Rhododendron. (66).

b. Corolla regular, saucer-slaped, 10-saccate, the anthers at first held in the little sacs.

Kalmia. (fī) .

41. Choripetalons plants in which the petals are sometimes partly or completely mited.

a. Ovulary 1-locular (1 carpel) with 1 parietal placenta. Findikit:

See 15 above.

a. Ovulary t-k-locular, with 1 or 2 orules in each cavity. TLICICEAE.

See 2:3 above.

4.2. Stamens as many as the lobes of the small white corolla: leaves entire, simple and alternate: with thorns. SAPOTACEAE.

a. Bumelia. (699).

4.2. Stamens twice as many as the lobes of the greenishyellow corolla or more; styles 2-8; plants mostly monecious or diecious: leaves alternate, simple. and entire. ERENACEAE.

a. Diospyros. (7i) .

4:). Flowers regular, stamens usually :2. OLE.ACEAE.

a. Chionanthus. (73).

13. Flowers irregular, zygomorphic; seeds numerous. stancu- 1, diclynamous: pith with cavities. Some -_SCROPHTLI.IRIACE.AE. 
a. Paulownia. (76).

4:3. Flowers irregular, zygomorphic; seeds numerous. fertile stamens usually 22 with 3 vestiges: pitl. solid. BigNONIACEAE.

i. Catalpa. (77).

14. Staments twice as many as the lobes of the corolla or more: leaves alternate and simple. 4h.

44. Stamens as many as the lobes of the corolla: leave: opposite or whorled, simple. 46 .

1.i. Corolla yellow; stamens in several series. Sympocicene.

a. Symplocos. (71)

fi. Corolla white: stamens in one series. STrRAincal.

a. Halesia. ( $7 \cdot 2)$.

46. Stipules present: flowers in dense heads in our species: usually blackening in drying. Rumiclise.

\section{a. Cephalanthus. (\&.2).}

46. Usually without stipules: flowers in compound cymes in our species; not blackening in drying. C.IPRIFOI.IACE.ICE.

a. Viburnum. (8:3). 


\title{
CLASSIFICATION AND DESCRIPTION OF THE SPECIES.
}

\author{
SPERMATOPHYTA. SEED-PLANTS. \\ Phylum, CYCADOPHYTA. \\ Class, Ginligoeae. \\ Order, Ginkgoales. \\ Ginkgoaceae. Ginkgo Family.
}

1. Gínkgo Kaempf. Finkgo.

Trees with dichotomonsly veined, fan-shaped leaves on thick. wart-like, persistent, dwarf branches.

Stamens and carpels in clusters on the dwarf branches. appearing with the leaves.

1. Ginkgo biloba. L. Maiden-hair-tree. A large, beautiful and hardy tree with diecions flowers. Seed large, drupelike. Autumn leaves orange. Introduced from China and Japan: should le commonly cultivated for ornament.

Phylum, STROBILOPHYTA.

Class, Coniferae. Conifers.

Order, Pinailes.

Taxodiaceae. Bald-cypress Tamily.

2. Taxòdium Rich. Bald-cypress.

Trees with feather-like, annually deciduous dwari branches with the uumerous, small, narrow leaves usually spreading into two ranks, and liaving the slender twigs covered with small sclf-pruning scars.

Tall trees with horizontal or drooping loranches: monecious: carpellate cones globose. in small terminal clusters: their scales few, each with two ovules at the basc.

1. Taxodium distichum (L) Rich. liald-cypresis. A large tree, the old bark flaky in thin strips. The roots derelop upright conic "knees." Wood light, soft, brown and very durable. In swamps and along rivers. N. I. to fla.. west to Tex., north to Mo. and Ind. 


\section{I'inacese. P'ine Family.}

\section{Pìcea Link. Spruce.}

Evergreen trees with f-angled leaves, all of about the same length, having the twigs covered with sterigma-bearing scales representing leaf bases.

Conical trees with leaves spirally arranged and spreading in all directions; monecious; staminate and carpellate cones often highly colored; carpellate cones pendulous.

1. Twigs and sterigmata glabrous: carpellate cones cylindric. 2 .

1. Twigs pubescent, brown; carpeliate cones ovoid or oval. 3.

2. Leaves usually $3-1$ in. long: carpellate cones $2 \frac{1}{2}-f_{i}$ in. long. P. abics.

2. Leaves usually not much over 1.2 in. long: very glaucous; carpellate cones ${ }_{4}^{3}-2$ in. long. $P$. canadcnsis.

3. Leaves not glancous; cones deciduous at the end of the first season. P. rubens.

3. Leaves glaucous; cones persistent for two or more seasons. P. mariana.

1. Picea ábies (L.) Karst. Norway Spruce. A large tree, conical in shape when young, with numerous stout spreading and drooping branches: Abundant in cultivation. Source of Burgundy pitch. Native of Europe.

-. Picea canadénsis (Mill.) B. S. P, White Spruce. I slender tree sometimes with a strong skunk-like odor. Leaves light green, slender, $\frac{1}{2}-\frac{3}{1}$ in, long. very acute. An important timher tree with lisht, soft, weak, and straightwrained wood. Newf. to Alaska, somtl to Me,. Mich., and S. Dak.

3. Picea rùbens Sarg. Red Spruce. I slender tree with spreading liranches, and slender, sparingly pubescent twigs. Wood soft, weak and pale reddish. Newf. to northern N. Y. and Minn.; along the Alleghanies to $\mathrm{Va}$. and $\mathrm{Ga}$.

4. Picea mariàna (Mill.) 13. S. P. Black Spruce. A tree with spreading branches and smooth or only slightly roughened bark. leaves not over $\frac{2}{3}$ in. long, stout, green, dnsely covering the twigs. Wood light and straight-grained: 
used for paper pulp, for general lumber and for masts and spars of ships. Newf, to X. W. Terr., south to X. J., I. C.. Mich., and Minn.

\section{Tsùga Carr. Hemlock.}

Evergreen trees with flat linear leaves, those on the top of the twig short, and having the twigs covered with sterigmabearing scales representing leaf hases.

Branches slender, horizontal or drooping: leaves spreading more or less into -) ranks: monecious; carpellate cones small, pendulous.

1. Tsuga canadénsis (L.) Carr. Hemlock. A tall tree with slender, horizontal or drooping branches, the old hark flaky in scales. Wood very coarse, light, brittle, and soft: used for wood pulp. Bark used for tanning. Source of Canada pitch. Self-prunes twigs. X. S. to Minn. south to Ohio, and Del., along the Mlleghanies to Ala., and to Mich. and $\mathrm{W}$ is.

\section{$\therefore$ Àbies (Tourn.) Hill, Fir.}

Evergreen trees with flat linear leaves, rarely prismatic, without sterigma-bearing scales, but with prominent circular leaf scars with a central bundle scar.

Carpellate cones erect, the scales deciduous: monecious: carpellate bract longer than the ovuliferous scale.

1. Carpellate bract serrulate, shorter than the ovuliferous scale or but little longer: leaves obtuse. A balsamea.

1. Carpellate bract aristate, longer than the oruliferous scale: leaves mostly emarginate. 1 frascri.

1. Abies balsàmea (L.) Mill. Balsam Fir. A slender short-lived tree with smooth blistered bark. Wood very light and soft. Canada balsam is obtained from its resin. Newf. to Hudson Bay and Alberta, south to Penn., along the Alleghanies to Va., and to Mich., Iowa; and Minn.

?. Abies fràseri (Pursh) - Poir. Fraser Fir. A slender tree growing on the ligh Nlleghanies. Bark smooth, with resin blisters. IV. Va., N. Car., and Tenn. 


\section{(i. Làrix (Tourn.) Arlans. Larch.}

Trees with thick wart-like dwarf branches hearing a cluster of deciduous needle-shaped leaves.

Tall pyramidal, monecious trees with horizontal or ascending branches; carpellate cones small, erect, with thin woody scales.

1. Carpellate cones small, $\frac{1}{2}-\frac{3}{1}$ in. long, uval or ahmost glohular: ovuliferous scales glabrous: native, growing in bogs and. wet places. L. laricina.

1. Carpellate cones rather large, $3-13$ in. long: oruliferous scales finely tomentose on the back, cultivaterl in dry ground. L. larix.

1. Larix larícina (1)uRoi) Koch. Tamaract. I slender tree with close or at length scaly bark. Wood hard, durable, and rery -strong: used in ship-building, for railroad ties, posts, and telegraph poles. In swamps and about the margins of lakes. Newf, to $\mathrm{N}$. W. Terr., south to Minn., Ind.. Ohio, and N. J.

2. Larix làrix (L.) Karst. European Larch. A beautiful tree with horizontal branches and drooping branchlets. conical in shape when young: much cultivated in some parts of the United States. The source of Venice turpentine. Native of Europe.

\section{Pìnus (Tourn.) 1.. l'ine.}

Evergreen trees with self-pruned dwarf branches hearing 1-i needle-shaped leaves.

Resinous, monecious trees with very small dwarf branches: dwarf branches and ordinary twigs covered with scale leaves. 1)warf branches self-pruned after a number of years. Carpellate cones woody with numerous carpels. (Our most important lumber trees:

1. Dwarf branches with is ficliage leaves: oruliferous scales little thickened at the tip. P. strobus.

1. Dwarf branches with 2-33 foliage leaves: ovuliferous scales much thickened at the tip. :2.

2. Dwarf branches with 3 foliage leaves, rarely -? or 1. :3. 


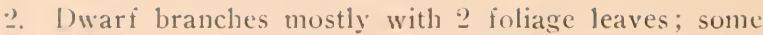
of them may be with 3 . 5.

3. Leaves 6-10 in. long: carpellate cone oblong-conic or ovoid. 4.

3. Leaves $3-5$ in. long; carpellate cones ovoid. 1 . rigida.

1. Old sheaths of the dwarf branches $3_{3}^{2}-1$ in. long; leaves not glaucous: carpellate cones oblong-conic. $P$ '. taeda.

4. Old sheaths about $\frac{1}{2}$ in. long; leaves glaticous; carpellate cones ovoid. $P$. scrotina.

i. Twigs glaucous; resin-ducts parenchymatous; carpellate cones $1 \frac{1}{2}-3 \mathrm{in}$. long; ovuliferous scales with a prickle or small spine. 6 .

$\therefore$ Twigs not glaucous. 7 .

i. Leaves slender, 21-.; in. long; buds not very resinous; prickles of the ovuliferous scales short and sinall. P. cchinata.

i. Leaves stout, $1 \frac{1}{2}-21$ in. long; buds very resinous: prickles of the ovuliferous scales long and stout. P. arirginiana.

7. Leaves 1-4 in. long, grayish-green or light green: ovuliferous scales without or with a small prickle. or with a thick point or spine. ?.

7 Leaves 4-6i in. long, dark-green; ovuliferous scale without a spine or prickle. or sometimes with a very small prickle. ?.

$\therefore$ Foliage lustrous, resin ducts peripheral; carpellate cones terminal or subterminal, oval-conic: ovuliferous scales pointless when mature. $P$. resinosa.

$\therefore$ Foliage dull; resin ducts parenchymatous: carpellate cones lateral, ovoid-conic; ovuliferous scale with a small prickle. P. laricio.

!) Leaves $21-4 \mathrm{in}$. long, grayish-green; twigs orange or hrown; resin ducts parenchymatous; carpellate cones ovoid; 3-5 in. long. P. pungens.

9. Leaves $\frac{1}{2}-2 \frac{1}{2} \mathrm{in}$. long. 10 .

10. Leaves $1 \frac{1}{2}-2 \frac{1}{2}$ in. long, grayish-green; twigs dull greenish-yellow or greenish-brown; resin ducts peripheral; carpellate cones ovate-conic, ․-3 in long. $P$. siliestris. 
11. Leaves $\frac{1}{2}-1 \frac{1}{2}$ in. long; resin ducts parencliynatous: carpellate cones oblong-conic, 1-2 in. long, usually upwardly curved. $P$. banksiana.

1. Pinus stròbus L. White Pine. A large tree with nearly smooth bark, except when old; branches horizontal in whorls. Often forming dense forests. IVood soft and straight-grained; used in enormous quantities for building purposes. One of the most valuable timber trees in the world. Has heen more extensively used in America for lumber than any other tree. Newf, to Man., south along the Allegh. to Ga. and to Ohio, III. and Ia.

․ Pinus taèda $\mathrm{I}$. Loblolly Pine. A large tree of very rapid growth with spreading branches and thick, rugged bark, flaky in age. IVood rather hard; much used for lumber in the south. Often growing in old fields. N. J. to Fla., Ark., and Tex.

3. Pinus serótina $\mathrm{M} x$. Pond Pine. A tree, usually with a short trunk and with the bark fissured into small plates. In swamps and ponds. IVood soft, brittle, and coarse-grained. Coastal plain. N. J. to Fla.

4. Pinus rígida Mill. Pitch Pine. A tree with spreading branches, the old bark rough and furrowed, flaky in strips. Sprouts readily from the stump if cut down or burned. WVod rather hard and brittle and full of resin; used for fuel, charcoal, and coarse lumber. A source of turpentine to a limited extent. In dry, sandy or rocky soil. X. T. to Ont., Tenn.. Ohio, IV. Va. and Ga.

$\therefore$ Pinus resinòsa Ait. Red Pinc. I tall tree witl reddish bark. Wood rather hard but not very durable. Turpentine is obtained to a limited extent from, this species. I tree of rapid growtl. Newf, to Man., Mass., Penn., and Iinill.

(i. Pinus laricio Poir. Iustrian Pine. I tall, open. pramiclal tree of rapid growth with the thich spreading l,ranches in regular whorls. Often cultivated. From Europe.

7. Pinus silecstris L. Scotch Pine. A large and valuable tree with drooping hranches: mucl cultivated. From it aro obtained the red and yellow deal much used as lumber in Europe. Native of northern Europe. 
․ Pinus banksiana Lamb. Jack Pine. A slender tree with spreading branches, the bark becoming llaky. Wood light and rather soft. In sandy soil. $\mathrm{N}$. P. and $\mathrm{N}$. W. Terr., south to Me., N. Y., I11., and Minn.

4. Pinus echinàta Mill. Yellow Pine. A large tree with spreading branches: leaves sometimes in :3's, sometimes in 2's Wood rather hard and very valuabe: much used as lumher. Ilso furmishes some turpentine. Produces shoots from stumps. In sandy soil. N. Y. to Fila., Ill., Oki., and Tex.

11. Pinus pùngens Lamb. Table-mountain Pinc. I tree with spreading branches, the old hark rongh and in flakes, leaves sometimes in 3 's. Wood light and soft: much used for charcoal. N. J. to (ia. and Temm.

11. Pinus virginiàna Mill. Scrub Pine. A slender. usually small tree with spreading or drooping branches; the old bark flaky and dark-colured. Wood very resinous, soft and durable but of poor quality. In sandy soil. L. I. to S. C.. tla., Tenn., ()hio, and Ind.

\section{Juniperuceac. Juniper Family. Sulsfamily, Cupressatac.}

×. Thùja $\mathrm{I}$. Arborvitae.

Evergreen trees or shrubs with decidedly flattened and fan-like twigs. and with naked buds, the small leaves opposite, scale-like, appressed and 4 -ranked ; carpellate cone oblong, with li-ll" scales the 4 upper fertile.

Resinous and aromatic; flowers minute, monecions : orules ustrally - on each scale, erect: scales iry coriaceous, not peltate.

1. Pranchlets spreading more or less horizontally with a distinct upper and lower side: carpellate cones pendulous, the thin scales appendiculate below the apex: sceds winged. $T$. occidentalis.

1. Pranchlets in a vertical plane with both sides alike: carpellate cones erect, the scales with a prominent horn-like process below the apex; seeds wingless. T. oricutalis.

1. Thuja occidentàlis L. American Arborvitae. Usually a small conical tree with fan-like branches. Self- 
prunes twigs. Wood light and durable; used for posts, railroad ties, etc. Usually in wet soil and along the banks of streams. N. B. to Man., south to Ohio and $\mathrm{X}$. J., along the Alleghanies to $\mathrm{N}$. C., and to 111. and Minn.

2. Thuia oricutalis L. Chinese Arborvitac. A small pyramidal or bushy tree with spreading and ascending branches. Native of Isia. Cultivated in many forms.

\section{Libocèdrus Endl. Incense-cedar.}

kiergreen trees with naked huds and small, scale-like. appressed, opposite, t-ranked, usually elongated leaves on somewhat flattened branches: scales of the carpellate cone 4-li, the two upper fertile, not peltate.

Tall, resin us aromatic trees with scaly bark, monecious; staminate and carpellate cones on separate branchlets: seeds with mequal lateral wings.

1. Libocedrus decurrens Torr. Incense-cedar. A tree with a tall, straight, slightly lohed trunk, tapering from a hroad base. Wood light, soft, close-grained, and very durable in contact with the soil. From the Pacific coast: often. cultivated as an ornamental tree.

\section{Chamaecýparis Spach. White-cerlar.}

Evergreen trees with small, scale-like appressed, nearly or quite similar leaves, naked buds, and dry peltate carpellate scales with $2-4$ sceds.

Monecious: carpellate cones glolose, with thick, opposite scales, each with a central point.

1. Leaves dull blue-green: hark thin, divided into tlat ridges. (C. thyoides.

1. Leaves bright green; hark thick, divided into hroad ridges. C. lawisoniuno.

1. Chamaecyparis thyòides (1..) B. S. P'. Southeru White-cedar. A tree with soft, light, and durable wood: used for boat-building, woodenware, shingles, etc. In swamps. Maine and N. H. to X. J., Fla., and Miss.

2. Chamaccyparis laisoniana (Murr.) Parl. Lawson Cypress. A large tree with an abruptly enlarged base and a spire-like crown of small horizontal or pendulous branches. 
bark often 111 in. thick. Wood light, hard, and strong, abounding in fragrant resin. From the Iacilic coast. Man! varieties in cultivation.

\section{Subfamily, Juniperatac.}

11. Juníperus I. Juniper.

Evergreen trees or shruhs with naked buds, subulate or scale-like leaves, one or both kinds on a tree, and with carprellate cones developing into a bluish-black berry-like fruit.

Carpellate cones small, globose: plants usually diecions. sometimes monecions, pungent aromatic: hark usually thin and shreddy:

1. Leaves all sublate, prickly pointed, verticillate, slender. mostly straight; cones axillary. J. communis.

1. Leaves of 2 kinds. scale-like and subulate, opposite or verticillate; cones terminal. J. airginiana.

1. Juniperus commùnis 1 . Common Juniper. A low tree with spreading or drooping liranches and slireddy bark. Goats are poisoned from eating the leaves. On dry hills. $X$. $\therefore$ to Mlaska, south to I. J., Ohio, Mich., Nel), and in the Rocky Mts. to N. Mex. N/so in Europe and Asia.

¿. Juniperus virginiàna [. Red Juniper. A tree, witl] sprearling often irregular branches when old, hut conic in shape when young. Self-prunes twigs. Wood very valuable. light, straight-grained, durable, and fragrant: used for posts. (ahbinetwork, interior finish, veneers, moth-proof chests and cooperage, and almost exclusively in the manufacture of lead pencils. Often infested with the "cedar apple." Poisunons to goats. In dry soil; common on bluffs. X. R. Lo western ()nt. and S. Dak., sunth to Fla. and Tex.

\section{Phylum, ANTHOPHYT.A.}

Class, Dicutrink. Dicotyls.

Suluclass, This.amifLor.le.

Order, Raxales.

Uasnoliaceac. Magnolia Family:

\section{1.). Magnòlia 1.. Magunolia.}

Shrubs or trees wth alternate, simple, entire leaves, not truncate, and with complete stipular rings. 
Bark bitter aromatic: flowers bisporangrate, large, solitary: luts covered with comnate, sheathing stipules: pith ustually diaphragmed but solid; fruit aggregate, cone-like.

1. Leaves auriculate, glabrous. Leaf buds glabrous. M. fraseri.

1. Leaves rounded or truncate at the base, thin. Leaf huds silky pubescent. M. acuminata.

1. Leaves acute at the base. 2 .

2. Leaves light green beneath, 1-2 ft. long. Leaf buds glabrous. 1 . tripetala.

2. Leaves glaucous beneath, 3-6 in. long. Leaf buds pubescent. M. airginiana.

1. Magnolia acuminàta L. Cucumber Magnolia. A large tree with silky pubescent leaf-buds. Leaves oval, acute or somewhat acmminate, rounded or truncate at the base $\frac{1}{2}-1$ ft. long; flowers greenish-yellow. Wood soft, light, and durable: used for cahinet-work, pump-logs, and water-troughs. X. Y. to Ontario and Mo., Ga., Ala., and Ark.

2. Magnolia tripétala L. Umbrella Magnolid. A low trec with glahrous leaf-buds and irregular branches. Leaves ohovate, acute, cuneate at the base, 1-2 ft. long, flowers white. slightly odorous. Wood soft and light. Penm. to Ga.. Mo.. Irk., and Miss.

7. Magnolia virginiána I.. I aurel Magnolial. I tree with pubescent leaf buds. Leaves oval or olslong, acute at the base, :3-6 in. long; flowers white, deliciously fragrant. In swamps. Mass. to Penn., Fla., Ark., and Tex.

1. Magnolia fràseri Walt. firaser Magnolia. A tree with spreading branches and glabrous leaf huds. Leaves clongated-obovate or whlong, auriculate, $\frac{1}{2}-2$ ft. long: flowers white. In monntain woods. Va. and Ky. to Fla. and Miss.

Various Magnolias are in cultivation, the more common une is Magnolia soulangiana, Soulange's Magnolia, a small tree with large purplish-pink flowers appearing hefore the leaves.

\section{Liriodéndron 1. Tuliptrec.}

Trees with alternate, truncate, simple leaves, with solid, diaphragmed pith and enmplete stipular rings. 
Buds with comnate stipules: Howers large, perianth trimerois: anthers linear, extrorse: fruit aggregate, conelike, dry:

1. Liriodendron tulipífera L. Tiliptree. I very large. magnificent, rapid-growing tree with glalorous leaf-buds. lilowers greenish-yellow, orange-colored within. Intumn leaves pure yellow: Vext to the Sycamore, probably the largest tree in the lortheastern Lnited States: trunk sometimes 34 $\mathrm{ft}$ in circumference. Wood light, soft, and straight-grained, easily worked: heart wool light yellow or brown: sapwood thin, nearly white. ['sed for interior finish, shingles, boathuilding, panels of carriages, wooden pumps, wooden ware of iarious kinds. Wood ptulp), furniture, implements, boxes, shelving, drawers, and for carving and toys. One of the best woods for pancling. Should be extensively cultivated. It. and R. I. to Fla., Mich., Irk., and Miss.

Anonacere. Custard-apple fiamily.

14. Asímina Arlans. Papari.

lrees or shrubs with alternate, -2-ranked, simple, entire. pinnately veined, decicluous leares and diaphragmed, solid pith.

Buds naked, silky: hark with fetid odor: perianth trimerous: stamens numerous: carpels :3-15.

1. Asimina tríloba (L.) I) unal. I'apalw. A small tree or shrul, with smooth dark bark and nodding young twigs. Flowers axillary. nodding: fruit a large fleshy, oblong. yreenish-yellow, edible herry; which, however, does not agree with some persons. A case of severe poisoning from eating the fruit is recorded. In creek and river bottoms and on hillsides. Ont. and X. Y. to Mich., Neh., Tex., and Fla.

\section{L.auraceac. Laurel Family.}

\section{1.. Pérsea (Plum.) Gaertn. Bay.}

Aromatic, evergreen trees or shrubs with alternate, simple, pinnately veined, entire leaves.

Perianth fi-parted: stamens and staminodes 12, in 4 series: fruit a globose or ohlong herry.

1. Persea borbonia (L.) Spreng. Red Bay. A tree with dark red bark, lanceolate or olblong-lanceolate leaves, and 
puberulent or nearly glabrous leaves. Ifood hard, strong. bright red in color, and rather brittle: used for cabinet-making. and interior linish. Mlong streams and the border of swamps. Del. to Fla., Ark., and Tex.

\section{Sássafras Nees and Eberm. Sassafrás.}

Trees with entire or :-lohed, alternate leaves with prominent lateral veins, with spicy aromatic bark and unequal internodes.

Flowers diecious: perianth li-parted; fruit a hlue drupe.

1. Sassafras sássafras (1.) Karst. Sassairas. A large rough-barked tree, the sap of the bark and leaves mucilaginous. Antumn leaves red, yellow, and green. Wood reddish. light and rather soft, of coarse texture, durable: used in cooperage, for small boats, and fencing. The bark of the roots yields a powerful, aromatic stimulant Fruit pungent, poisonous. Excessive doses of sassafras tea produce narcotic poisoning. In dry or sandy soil. Me. to Ont., Mich., Iowa. Fla., and Tex.

\section{Order, Geranidats.}

Rutaceas. Rue Family.

\section{Zanthóxylum 1.. Prickly-ash.}

Trees or shrubs with alternate, pinnately compound, punctate leaves and with stipular spines.

Bark acrid aromatic: flowers imperfectly diecious: frut a capsule with 1-丷) seeds.

1. Zanthoxylum americànum llill. Prickly-anh. I prickly shrub or small tree with small flowers in sessile axillary cymes; stamens :3-i); (carpels 2)--i, distinct, seed oblong. black and shining. Wood soft and light brown. In woods and thickets. Quehec to Va.. Ontario, S. Dak, and Kan.

\section{1.. Ptèlea L. Hoptrec.}

Shrubs or small trees with alternate, trifoliate, punctate leaves and superposed buds covered ly the petiole hase.

liark bitter: Howers imperfectly monosporangiate: stamens 1-i; fruit a santara with a membranous wing: ovulary 2 -locular. 
1. Ptelea trifoliàta 1. Hoptrec. I shrul) or small tree with sunken superposed axillary buds covered by the petiole base. Bark and flowers with a disagreeable odor. Wood light brown, heavy, and hard. In woods. Conn. to Fla., Ont., Minn., Kan., and Mexico.

Simarubaceac. Ailanthus Family.

19. Ailánthus Desf. Ailanthus.

Large trees with alternate, pinnately compound, large leaves having green glands on the under side of the teeth at the base of the leaflets.

Branches robust with large brown pith; flowers diecious: the 5 samaras linear or oblong, usually twisted.

1. Ailanthus glandulòsa Desf. Tree-of-heaven. A large tree of rapid growth with thick branches and smooth bark. Leaves ill-scented; leaflets with green glands under the lobes or teeth. Autumn leaves pure yellow. Wood hard and useful. Sprouts freely from the roots and is easily. propagated from root cuttings. A pest in pastures in some states; cows will not eat grass near the young shoots. Water contaminated by the leaves is poisonous. Naturalized from China. Ont. to Mass., Va., and Kan.

\section{Order, Malvales.}

Tiliaceae. Linden Family.

\section{Tília (Tourn.) L. Linden.}

Trees with 2-ranked, simple palmately veined, inequilateral, serrate or clentate leaves and solicl pith.

Flowers bisporangiate, pentamerous, stamens numerous: dry drupaceous fruit in cymose clusters, the peduncle sulptended by a broad membranous bract.

1. Leaves glabrous or nearly so on both sides, except on the veins and in their axils. 2.

1. Leaves glabrous above, pubescent beneath. $T$. pubescens.

1. Leaves glabrous ahove, silvery-white heneath. $T$. heterophylla.

2. I'etals with scales at the base; inflorescence without bracts; leaves comparatively large; native. $T$. americana. 
$\because$ Petals without scales at the base: inflorescence with large bracts; leaves comparatively small; cultivated. T. europaca.

I. Tilia americàna L. Imerican linden. A largec, straight-trunked tree with spreading branches. Inner bark very tough; used for mats and coarse rope. Wood soft and very white, light and uniform in texture, not liable to crack; called "basswood;" used for wooden-ware, cabinet-work, trunks, panelling of carriages, in cooperage, and for toys. The bark and wood of the other lindens are much the same. In rich soil, on bluffs, and along river bottoms. N. B. to Ga.. Manitoba, Kan., and Tex.

¿. Tilia pubéscens Ait. Downy Linden. I small tree growing in moist soil, mostly along the coast. Wood as in T. americana but lighter in weight. Va. to Fla., west to Tex.

$\therefore$ Tilia heterophýlla Vent. White Linden. A tree with larger leaves than either of the preceding species. Wood weak, light brown. N. Y. to Fla., Ala., Ill., and Tenn.

4. Tilia curopaia L. European Linden. A large tree much cultivated in parks. Its name, Lin, was the origin of the family name of Linnaeus.

\section{Subclass, Calyciflorae.}

Order, Rosales.

Rosaceac. Rose Family.

Malatae. Apple Subfamily.

\section{Sórbus ('Tourn.) I. Mountain-asł.}

Trees or slurubs with alternate, odd-pinnate leaves, terninal huds, cylindrical pith, and :-5 hundlescars in the narrow leaf sear.

[ilowers bisporangiate: fruit a small red berry-like pome, in compound cymes.

1. Leaflets glabrous above. 2.

1. Leaflets pubescent on both sides; calyx and pedicels usually woolly. S. aucuparia.

$\because$ Leaflets long-accuminate; fruit less than $f$ in. in diameter. S. americana.

. I.caflets obtuse or short-pointed; fruit more than 1 iil. in diameter. S. scopulina. 
1. Sorbus americàna Marsh. American Mountainash. A small tree with smooth hark. liark and unripe fruit very astringent. Wood soft, light brown. In moist ground. Much prized for ornamental planting. Newf. to Man., N. Car., and Mich.

2. Sorbus scopulina Greene. Western Mountain-ash. A small tree with smooth bark. In moist ground. Lab. to Alaska, N. Eng., Ohio, Mich., and in Rocky Mts. to Colo. and Utah.

3. Sorbus aucupària L. European Jountain-ash. I small tree, native of Europe. Frequently cultivated. Fruit poisonous to man, but eaten hy some hirds. N. S. to N. H.

\section{2.). Pỳrus (Tourn.) L. Pear.}

Trees or shrubs with alternate, simple, pinnately-veined. serrate leaves with long petioles; with stipules or stipular scars; with terminal buds, cylindrical pith, and fruit a pome witlı grit cells.

Flowers hisporangiate with a Heshy hypanthium united with the ovulary: pentamerous: stamens numerous.

1. Pyrus commùnis L. Pear. A pyramidal usually slender tree, often with thorn-like stunted branches. Bark smooth. Wood hard, fine-grained, reddish-brown. Cultivated for its large fleshy fruit. Native of Europe and Asia. Me. to I. J. and Ohio.

\section{:2: Màlus Mill. Apple, (rab-apple.}

Trees or shrubs with alternate, simple, pinnately-reined, dentate, serrate or more or less lobed leaves, with stipules or stipular scars: with terminal buds, cylindrical pith, and fruit a pome without grit cells.

Flowers bisporangiate with a fleshy hypanthium united with the ovulary, pentamerous, stamens numerous.

1. Leaves glabrous, at least when mature. .).

1. Leaves persistently pubescent or tomentose beneath. 3.

2. Leaves oblong, oval, or lanceolate, narrowed at the hase. M. coronaria.

$\because$ Leaves ovate, romnded or cordate at the hase, often somewhat lohed. 1/. glaucoscens. 
2. Leaves ovate, acute or acuminate at the apex and acute at the base, on slender petioles: finely and nearly evenly serrate. $1 /$. baccala.

3. Leaves mostly narrowed at the base: pome 1-2 in. in diameter. M. iocnsis.

3. Leaves rounded or cordate at the base; pome usually large, 2-4 in. in diameter. M. malus.

1. Malus coronària (L) Mill. Narrow-leaf (rab-apple. A small tree usually with thorn-like stunted branches or spurs. Leaves oblong, oblong-lanceolate, or oval, thick, shining above, sometimes pubescent beneath when young, dentate or often entire. Wood hard, reddish-brown. On low ground. N. J. to Ill., Kan., Fla., and La.

2. Malus baccàta (L.) Borck. Siberian Crab-apple. A small spreading tree with compact crown. Pedicels very slender; fruit small, not becoming mellow. Cultivated.

3. Malus glaucéscens Rehd. Fragrant Crab-apple. A small tree with hard and sour fruit suitable for preserving. Leaves ovate, to triangular-ovate, sparingly pubescent beneath when young. sharply serrate and often somewhat lobed. Wood soft and reddish-brown. On low ground. Ont. to Mich., S. Car., Iowa, and Mo.

4. Malus ioénsis (Wood) Britt. Iowa Crab-apple. A small tree much resembling $M$. glauccsscens. Leaves ovate. oval, or oblong, dentate, crenate or with a few rounded lobes, white, pubescent beneath, at length glabrous above. Minn.. Wis., and 111. to Neb., Ky., La., and Okla.

$\therefore$ Malus màlus (L.) liritt. Common Apple. I medium-sized tree with spreading branches. Leaves orate or oval, glabrous or nearly so ahove, pulsescent and often woolly beneath. Fruit large, varions. Introduced from Europe and escaped in many places. The seeds are poisonons. Me. to N. Y., N. J., Ohio, and Ga.

\section{Cydònia Turrru. Quince.}

Shrubs or low small trees, our cultivated species with alternate, simple, pinnately veined, entire, deciduous leaves with stipules or stipular scars: cylindrical pith, and with frut a pome containing many seeds in each cavity. 
Filowers bisporangiate, perianth pentamerous, pome fleshy.

1. Cydonia cydonia (L.) Karst. Quince. A low tree with crooked stem and rambling branches. Cultivated for the large sour fleshy fruit.

\section{2.. Amelánchier Medic. Juneberry.}

Shrubs or small trees with alternate, simple, serrate, pinnately-veined leaves; with 3 bundle scars, terminal hud, a narrow leaf scar, and fruit a berry-like pome.

Flower bisporangiate, perianth pentamerous, pome small with twice the number of cavities as styles.

1. Leaves acute or acuminate at the apex; top of the ovulary glabrous or nearly so. 2 .

1. Leaves rounded, obtuse or subacute at the apex; top of the ovulary woolly; petals $\frac{1}{2}-\frac{3}{4}$ in. long. $A$. sanguinea.

2. Leaves glabrous when mature, but pubescent or woolly when young, ovate to ovate-lanceolate; hase cordate or rounded. A. canadensis.

-. Leaves densely white-woolly beneath, at least when young, oblong to obovate, rarely sub-cordate at the base. A. intermedia.

1. Amelanchier canadénsis (L.) Med. Common Juneberry. A medium-sized tree with a small, red or purple, sweet and edible, berry-like pome. Wood very hard, brown. In dry soil. Nova Scotia to Ont., Fla., La., and Ark.

2 Amelanchier intermèdia Spach. Swamp Junelerry. A shrub or small tree growing in swamps and moist soil. Variable. N. Eng. to Ont., Fla., and La.

$\therefore$ Amelanchier sangúinea (Pursh) I)(. Roundleat Junelerry. A tall shrub or small tree growing in woods and thickets. N. B. to Minn., N. C., and Mich.

\section{Crataègus L. Hawthorn.}

Small trees or shrubs with simple, serrate or lobed leaves, with stipules or stipular scars, and usually with typical axillary thorns, but without terminal thorns.

Flowers bisporangiate, perianth pentamerous, stamens -. p pome drupe-like with bony ripe carpels.

The species of Crataegus are at present in a very unsatisfactory conclitim. Prohahly many of those included 
helow are merely hybrids or forms of freely interbreeding elementary varieties. Many of the specific English names arc also unsatisfactory.

Required for identification, the leaves and fruit.

1. Leaves not deltoid-cordate. 2 .

1. Leaves conspicuously deltoid-cordate, glabrous. (Cor(atae). 5i).

2. Leaves glabrous, glabrous above and pubescent beneath, or pubescent on both sides. ?.

2. Leaves pubescent above, glabrous beneath; thorns \}-1 in. long; fruit black. (Douglasianae). it.

i. Petioles $\frac{1}{2}$ in. long or longer. 4.

3. Petioles less than $\frac{1}{3}$ in. long. (Parvifoliae). 53 .

4. Leaves not deeply cut. 5 .

4. Leaves deeply cut, lobes numerous; thorns less than 1 in. long (Oxyacanthae). 52.

$\therefore$ Leaves broadest at the middle or apex, cuneate. 6 .

5. Leaves broadest at the base. 12 .

f. Leaves broadest toward the apex. 7 .

6. Leaves broadest at the middle. 8.

7. Leaves shining, not impressed-veined above. (Crusgalli). 14.

7 Leaves dull, impressed-veined above. (Punctatae). 18.

8. Petioles usually glandless, or if so then the nutlets pitted on the ventral faces. 9 .

8. Petioles always with small stalked glands along their entire length; nutlets without ventral pits. (Intricatae). 30.

9. Calyx-lobes glandular-laciniate, glandular-serrate, or glandular-margined. 10.

9. Calyx-lobes not glandular-margined; leaves not impressed-veined, often trilobed towards the apex. (Virides). 29.

10. Leaves impressed-veined. 11.

10. Leaves not impressed-veined, elliptic ovate to orbicular; calyx-lobes glandular-margined; leaves not trilobatc (Rotundifoliae). 24.

11. Leaves rhombic-clliptic; calyx-lohes usually deeply cut; nutlets deeply pitted on the ventral faces. (Macracanthae). 21. 
11. Leaves elliptic to wate; calyx-lobes less deeply cut: nutlets with shallow pits on the ventral faces (Brainerdianae). 2:3.

1.2. Leaves $1-21$ in. long and wide, membranous; calyx-lobes usually entire. 1'?.

1.2. Leaves 1-4 in. long and wide; calyx-lobes usually serrate. (Coccincae). 14.

1:i. Leaves yellow-green often slightly pubescent; fruit soft at maturity. (Tenuifoliae). 34.

1:3. Leaves blue-green, usually glabrous: fruit hard at maturity. (Pruinosac). 38.

\section{- Crus-yalli. -}

14. Leaves not lobed. 15.

14. Leaves somewhat lobed. 16.

1.). Leaves $3^{3}-4$ in. long. C. crus-yalli.

15. Leaves $3-21$ in. long. C. berberifolia.

16. Styles and nutlets usually ".

$$
\text { C. schimophylla. }
$$

11i. Styles and nutlets usually 3-5. 17.

17. Lobes of the leaves irregular, ohtuse: fruit globose. C. denaria.

17. Lobes of the leaves regular, acute: calyx-lobes serrate. C. fecunda.

\section{- Punctatae. -}

1r. Fruit ellipsoidal; nutlets usually 3 or 4 . 19.

18. liruit globose. 2011.

1!). I.eaves bright yellow-green, slighty impressed-reined above. C. cunciformis.

1!1. Leaves dull gray-green, stromgly impressed-veined above. obovate, narrow. C. punctuta.

20. Nutlets 2) or :3. (. maruaretta.

2). Nutlets 4 or $\therefore$. C. suborbiculata.

\section{- Macracanthas. -}

21. Leaves dark green, glabrous, and shining above, coriaceons. -.).

21. Leaves gray-green, pul)escent and dull above, subcoriaceous, rhombic-ovate, lobed. C. culpodendron.

2.). Fruit 2 in. thick or less: leaves large. C. succulenta.

2.2. Fruit $\frac{1}{2} \mathrm{in}$. thick or less: leaves small. C. mofluvialis. 


\section{- Brainerdiunac. -}

2.-. Firuit and corymbs pulescent; calyx-lobes sharply glandular-serrate; leaves serrate; styles and nutlets -2 or 3 . C. pertomentosa.

2):?. Fruit and corymbs glabrous; calyx-lohes remotely glandular-serrate. C. brainerdi.

\section{- Rotundifoliae. -}

-4. Leaves longer than wide. '5.

-4. Leaves ahout as wide as long. - $(i$.

․). Leaf lobes acuminate. $-C$. laurentiana.

2). Leaf lohes acute. C. lucorum.

2i. Leaf-lobes acuminate. C. irrasa.

?(i. Leaf-lobes acute or olstuse. 27 .

27. Calyx-tube prominent; fruit subglobose. C. macauleyac.

2-. Calyx-tube obscure. 28 .

2.R. I.eaves acutely lobed toward the apex; calyx-lobes glandular-laciniate. C. bicknellii.

․․ Leaves not acutely lobed; calyx-lobes glandular-margined only; fruit glolose, red, round in cross-section C. chrysocarpa.

- Firides. -

29. Leaves- ovate; lobes shallow; fruit yellow-red. C. ovatu.

29. Leaves oblong-ovate lobes deep; fruit bright red, glaucous. C. riridis.

- Intricatai. -

3i). Foliage and fruit pubescent; corymbs villous. 31.

30. Foliage, fruit, and corymbs glabrous. 3 ;.

31. Fruit glohose, greenish to reddish-brown. C. intricata.

31. Irruit ellipsoid or pyriform. yellow. C. stonci.

:i.). Leaves corclate, lobed. C. populifoliu.

:3). Leaves cuneate, lobed. :3:3.

:3: Leaves elliptic-ovate: fruit pyriform-ellipsoid. ( . straminea.

33. Leaves ovate to oval: fruit globose or subglobose, reddish-green to reddish-brown. C. boyntoni.

\section{- Temuifoliai. -}

34. Fruit ellipsoid, ovoid, or pyriform; calyx-lobes entire. 3.;. 34. Fruit compresserl-ghbose or sulghlohose. 3i.

35. Leaves much lobed; fruit small, $\frac{1-1}{1-3}$ in. thick, with rather firm flesh. C. roancnsis. 
3i. Leaver 110 conspicuonsly lobed; fruit large, $\frac{1}{2}-3 \mathrm{in}$. thick, with soft hesh. C. macrospirma.

3it. Lobes of the leaves reflesed. C. grayana.

:3i. Leaf-lobes spreading or ascending. 37.

:37. Terminal leaves cuneate. C. alnorum.

3i. Terminal leaves cordate. C. populnea.

\section{- Pruinosae. -}

3x. Leaves elliptic-ovate. C. icsuni.

3. Leaves orate. 39.

3!. Leaves usually cordate. 11!.

3!!. Leaves ustrally cuneate. 11.

411. Fruit conspicuously angled, strongly pruinose. C. rugosa.

40. Fruit not conspicuously angled, only slightly pruinose. C. filipes.

41. Lobes of the leaves deep, acuminate. C. leiophylla.

11. Lobes of the leaves shallow, acute. 42.

4.). Fruit without conspicuous angles. C. biata.

42. Fruit conspicuously angled. 43.

43. Leaves deltoid. C. gattingeri.

4:i. Leaves ovate. C. pruinoso.

\section{- Coccincac. -}

4i. Mature leaves usually glabrous ahove; young foliage bronze-green. 1.5.

4. Mature leaves tomentose above; young foliage yellowgreen. 5)

4.) Leaves oblong-ovate. 16.

4.). Leaves broally ovate. 47.

41. Corymbs nearly glabrous. C. itllipes.

41. Corymbs very pubescent. C. anomala.

47. Corymbs and fruit glabrons. C. coccinioides.

iT. Corymbs and fruit pubescent or tomentose $4 R$.

4x. Leaves on the vegetative shoots cuneate. 49.

4i. Leaves on the regetative shoots cordate. C. albicans.

1!. Leaves concave, $11-3$ in. long, $11-23$ in. wide. C. pringlei.

19. Leaves plane, 11-4 in. long, 1$\}-3 \frac{1}{2}$ in. wide. C. coccinea.

i). Leaves on the regetative shoots cuneate at the base. il.

iil. Leaves on the vegetative shoots cordate. C. mollis.

i1. Lobes of the leaves hroad, shallow, acuminate. $C$. arnoldiana. 
51. Lobes narrow, deep, and acute; fruit ellipsoid-pyriform. C. submollis. - Oryacanthac. -

52. Leaves ovate, $3-15$-lobed or cleft. C. monogyna.

$$
\text { Parifoliac. - }
$$

i3. Leaves small, subcoriaceous, corymbs 1-3-flowered. C. uniflora. - Momglasianac. -

it. Leaves subcoriaceous, petioles $1-3$ in. long. C. douglasii. - Cordatac. -

i.). Leaves often conspicuously 3-5-lobed, petioles $\frac{1}{2}-2$ in. long. C. phaenopyrum.

1. Crataegus crús-gálli I. Cockspur Hawthorı. A small tree with spreading branches and numerous slender thorns. Leaves coriaceons, shining above, sharply serrate. Fruit ellipsoid-ovoid to subglobose, greenish to red, flesh hard, remaining on the branches until late in the winter. The best hawthorn for hedges. N. Y. to Ont., south to Conn., Ga., and Kan.

2. Crataegus berberifòlia T. \& G. Barberry-leaf Hawthorn. A small tree with spreading branches and a broad crown, with few thorns, Leaves oblong-cuneiform. spatulate, or obovate, rough-pubescent ahove, white-pubescent or tomentose heneath. Fruit subglobose to short-ellipsoicl. yellow, orange, or red. Ky, to Mo, and the Gulf States.

3. Crataegus schizophýlla Eggl. Martha's Vineyard Hawthorn. A small tree with irregular ascending branches and numerous thorns. Leaves oblong-ovate to ovate, coarsely serrate with short acute lobes toward the apex, glabrous, slightly impressed-veined. Iruit pyriform-ellipsoid, dark red: nutlets ribbed on the back. Mass.

4. Crataegus denària Readle. Palmer's Hawthorn. A small tree with spreading branches and a round-topped crowil. Leaves oval, ovate, or oblong-ovate, often slightly lobed towards the apex. Fruit globose or subglobose, reddish-green or light red. In low rich soil. Ky. to Mo, and Miss.

$\therefore$ Crataegus fecúnda Sarg. liruiful llawllurn. I small tree with spreading hranches and numeroms thorm. 
Leaves oblong-obovate to oval. Firuit short-ellipsoid to subglobose, orange-red, slightly puhescent. Rich hottom lands. 111. and Mo.

\section{Crataegus cuneifórmis (Marsh.) Eggl. Marshall's} Hawthorn. A small tree witl widely spreading branches, dark brown scaly bark, and numerous, often branched thorns. Leaves oblanceolate-obovate. Fruit ellipsoid-pyriform, scarlet or dark red. N. Y. and Pa. to V'a, and Ill.

†. Crataegus punctàta Jacq. Dotted Hawthorn. A small flat-topped tree with horizontal or ascending branches and light gray thorns. Leaves obovate. serrate, doubly serrate, or lobed at the apex. Fruit short-ellipsoid, yellow or red, somewhat edible. Quebec to Pa., Minn., Iowa, and Ky.

8. Crataegus margarétta Ashe. Nargaret's Hawthorn. A shrub or small tree with ascending branches forming a round crown. Leaves oblong-obovate to ovate, serrate or doubly serrate, usually somewhat lobed. Fruit dull rusty green, yellow, or red, compressed globose to short ellipsoid. angular. Ont. to Iowa, Mo., Tenn., and Va.

9. Crataegus suborbiculàta Sarg. Caughuawaga Hawthorn. A small tree with spreading branches and a broad crown. Leaves ovate-orbicular. serrate or doubly serrate. Fruit globose or compressed-glohose. dull green to scarlet. In lime-stone areas. Nontreal to Nich.

11. Crataegus succulènta Schrad. Longthorn Hawthorn. A small tree with ascending branches forming a broal irregular crown, and with numerous bright, brown thorns. Leaves rhombic-ovate to obovate, doubly serrate and usually somewhat lobed toward the apex. Fruit subglobose, dark red. X. S. to Minn., X. C.. Neh., and Col.

11. Crataegus neofluviàlis Ashe. New River Hawthorn. A small tree with ascending and spreading branches, and numerous thorns. Leaves elliptic-orate to obovate, doubly serrate and somewhat lobed towards the apex, coriaceous. dark green and shining above. Fruit globose or short-ellipsoid, dark red. Vt. to Wis., N. C., and Iowa.

12. Crataegus calpodéndron (Ehrh.) Medic. Pear Hawthorn. A shrub or small tree with ascending and spreading branches forming a broad crown, with stout thorns and tomentose twigs. Leaves rhombic-ovate, acute or acuminate 
at the apex, doubly serrate. Fruit pyriform or ellipsoid, orange-red or red. N. Y. and N. J. to Minn. and Mo.

1:3. Crataegus pertomentòsa Ashc. Prairic Hawthorn. A small tree with nearly horizontal branches forming a flattened crown and with numerous curved thorns. Leaves oblong to obovate finely doubly serrate or lobed. Fruit globular or nearly so, cherry-red, villous when young. Rocky soil. Iowa, Mo., and Kan.

14. Crataegus bràinerdi Sarg. Brainerd's Hawthorn. A shrub or small tree with ascending branches. Leaves elliptic to ovate finely doubly serrate or lobed. Fruit shortellipsoid to globose, cherry-red to scarlet. New Eng. to Iowa and $\mathrm{Pa}$.

15. Crataegus laurentiàna Sarg. Fernald's Hawthorn. A large, much-branched shrub or small trec with long thorns. Leaves oblong to oblong-ovate, sharply doubly serrate or lobed. Fruit ellipsoid, dark crimson. Newf., N. S., Quebec, Me., and shores of Lake Superior.

16. Crataegus lucòrum Sarg. Grove Hawthorn. A shrub or small tree with ascending branches. Leaves oblongovate to broadly ovate, doubly serrate or lobed. Fruit pyriform - ellipsoid, crimson. Ill. and WTis.

17. Crataegus irràsa Sarg. Blanchard's Hawthorn. A shrub or small tree with numerous spines. Leaves ovate to elliptic, doubly serrate or lobed. Fruit subglobose to shortellipsoid, red or scarlet, somewhat pubescent. Quebec to Vt. and N. Y.

15. Crataegus macaùleyae Sarg. Macauley's Hawthorn. A small round-topped tree with somewhat pendulou:; branches. Leaves ovate to oval, doubly serrate or lobed. Fruit subglobose to short-ellipsoid, dark crimson. N. Y.

19. Crataegus bicknélli Eggl. Bicknell's Hawthorn. A round-topped shrubby tree with numerous stout thorns. Leaves ovate or oblong-ovate, sliarply doubly serrate and lobed. Fruit globose, red. Mass.

201. Crataegus chrysocàrpa tshe. Roundleai Haw thorn. A beautiful, round-topped shrub or small tree with numerous thorns. Leaves ovate-orbicular or obovate, doubly serrate or lobed, shining above. Fruit depressed-globose to short-ovoid, red. N. S. and N. P. to Saskatch,, sonth to N. C.. Neb., and N. M. 
21. Crataegus ovàta Sarg. () vate-leaf Hawthorn. I tree with yellow scaly bark. Leaves ovate-elliptic or obovate, coarsely serrate or doubly serrate, often somewhat lobed towards the apex, dark green and shining above. Fruit globose or compressed-globose, yellow to orange-red. River bottoms. $\mathrm{Ky}$. and Mo.

2.). Crataegus víridis L. Green Hawthorn. I tree with ascending branches and a broad crown, often without thorns. Leaves oblong ovate, serrate or doubly serrate, often lobed toward the apex, dark green and shining above. Fruit globose or compressed-globose, bright red or orange, glaticous. Alluvial soil. Va. to Fla., Ind., Ill., Kan., and Tex.

2:?. Crataegus intricàta Lange. Biltmore Hawthorn. An irregularly branched shrub or small tree with few thorns. Leaves elliptic-ovate to broadly ovate doubly serrate or lobed. rough-pubescent. Fruit short-ellipsoid to globose, greenishyellow or becoming dark reddish-brown, somewhat pubescent. Open rocky woods. N. Eng. and N. I., south to S. Car. and Mo.

24. Crataegus stònei Sarg. Stone's Hawthorn. A much-branched shrub or small tree with prominent thorns. Leaves oblong to oblong-ovate, doubly serrate or lobed. Fruit pyriform to short-ellipsoid, light yellow or yellow-green tinged with red. Rocky soil. Mass., Conn., and N. Y.

2.). Crataegus populifòlia Walt. Poplar-leaf Hawthorn. A shrub or small tree with ascending and spreading branches forming a round crown. Leaves deltoid-ovate or oblong-ovate, serrate or doubly serrate with acute lohes. Fruit globose, light red, without angles. Va. to S. C.

-2i. Crataegus stramínea Beadle. Alleghany Hawthorn. In irregularly branched shrub or small tree with occasional thorns. Leaves elliptic-ovate, doubly serrate or lohed. Iruit pyriform to ellipsoid, angular, yellow-green. Rocky hills. Vt. to Mich., south to Del., Ala., and Mo.

27. Crataegus boỳntoni 'Peadle. Poynton's Hawthorn. A round-topped, irregularly branched shrub or small tree with occasional thorns. Leaves oval to ovatc, doubly serrate or slightly lobed. Fruit subglobose, orange-red or red-brown. Shaly soil. Mass. to Mich., south to S. C. and Tenn. 
2.R. Crataegus roanénsis Ashe. Roanl Mountain Maw thorn. A shrub or small tree with ascending branches and numerons curved thorns. Leaves ovate or ublone-ovate, serrate with acute straight lobes. Fruit ellipsoid, ovoid, or pyriform, crimson. Quebec to Wis., N. C., and Tenn.

2!). Crataegus macrospérma Ishe. Variable Haw. thorn. I shrub or small tree with ascending branches and numerous thorns. Leaves elliptic-ovate to broadly ovate, doubly serrate and somewhat lobed. Fruit ellipsoid or pyriform, scarlet to crimson, often glaucous. N. S. and Maine to Minu., N. C., and T'cmu.

:31. Crataegus grayàna Eggl. Gray's Hawthorn. I large shrub or small tree with ascending branches. Leaves ovate, doubly serrate with 4-6 pairs of acuminate lobes. Fruit subglobose to short ellipsoid, angular, dark cherry-red. $\mathrm{N}$. Fing. to Ont. and N. Y.

31. Crataegus alnòrum Sarg. Edcon's Hawthorn. A broad shruh or small tree with ascending branches. Leaves ovate, serrate or doubly serrate with acute lohes. Fruit subslobose, slightly angular, dark cherry-red. N. Eng. to Mich. and $\mathrm{Pa}$.

32. Crataegus popùlnea Ashe. Gruber's Hawthorn. A shrub or small tree with a flattened round crown. Leaves broadly ovate to elliptic-ovate, slightly villous, serrate or doubly serrate, sometimes lobed. Fruit glabrous to shortellipsoid, scarlet. Inw ground. Ont. to Pa. and Del.

:3. Crataegus jésupi Sarg. Jesup's Hawthorı. I large shrub or small tree with ascending hranches. Leaves elliptic-ovate, serrate or clowhly serrate with 4 or 5 pairs of acute lobes. Fruit short-ellipsoid to pyriform, slightly angled, dark red. Vt. to IVis. south to Pa.

:3. Crataegus rugòsa Ashe. Rugose Hawthorn. A shrub or small tree with ascending hranches. Leaves broadly ovate, serrate or doubly serrate with 1-6 pairs of hroad acuminate lobes, glabrous. Fruit depressed-globose, bright red. Conn. to Pa., Ind., and N. C.

3i). Crataegus filipes Ashe. Peckwith's Hawthorn. I shrub or small tree with ascending branches and numerous thorns. Leaves ovate, serrate or twice serrate and lobed, glabrous. Fruit glohose or compressed-globose, cherry-red. IVestern N. Eng. to Mich. south to Pa. 
36i. Crataegus leiophylla Sarg. Maine's Hawtlorn. A large shrub or small tree with erect branches and numerous thorns. Leaves broadly ovate, doubly serrate, with $3-5$ pairs of acuminate spreading lobes, dull. Ir ruit pyriform to globose, slightly angular, bright or clark scarlet. N. Y. to Pa.

:ii. Crateegus beàta Sarg. 1)umbar's Hawthorn. A shrub or small tree with ascending or erect branches. Leaves ovate, doubly serrate with acute lobes, dull. Fruit short ellipsoid, slightly angular, crimson. Ont. to $\mathrm{Pa}$.

is. Crataegus gattíngeri Ashe Gattinger' Hawthorn. A shrub or small tree with ascending branches forming an irregular crown, and with numerous thorns. Leaves narrowly ovate to deltoid, serrate or doubly serrate, lobed toward the apex, glabrous, dark green above. Fruit globose, angular, red. $\mathrm{Pa}$. to Ind., south to W. Va. and Tenn.

39. Crataegus pruinòsa (Wendl.) Koch. Waxyfruited Hawthorn. A shrub or small tree with ascending branches, irregular crown, and numerous slender thorns. Leaves elliptic-ovate to broadly ovate, doubly serrate with 3 or 4 pairs of broad acute lobes toward the apex, glabrous. Fruit depressed-globose or short-ellipsoid, strongly angled, pruinose, scarlet or purple. Rocky open woods. N. Eng. to Mich., N. C. and Mo.

10. Crataegus víllipes Aslie. Thinleaf Hawthorn. I tree with strongly ascending branches. Leares elliptic-ovate, serrate or doubly serrate with 4-6 pairs of acute or acuminate lobes, pubescent or scabrous. Fruit pyriform or ellipsoid, crimson. Maine to Quebec to Mich., south in the mountains to N. C.

41. Crataegus anómala Sirry. Oblong-leai llawthorn. A shrubby tree with numerous thorns. Leaves oblong to ovate, serrate or doubly serrate with acute lobes. Fruit pyriform-ellipsoid, crimson. Quebec to Mass. and N. Y.

4.2. Crataegus coccinioides Ashe. Eggert's Hawthorn. A shrub or small tree with spreading branches. Leaves broadly ovate, doubly serrate, dark green above. Fruit subglobose, obtusely angled. Quehec to R. I., west to Mo. and Kan.

1:?. Crataegus prínglei Sarg. Pringle's Hawthorn. A small tree with ascending branches. Leaves ovate to oval, doubly serrate, with shallow lobes. Fruit short-ellipsoid to 
pyriform, pubescent, red. Wester11 X. Fing. to 111. south to Pa.

44. Crataegus coccínea L. Scarlet Hawtloril. A small tree with ascending and spreading branches and stout short thorns. Leaves broadly ovate, acute or acuminate at the apex, broadly cuneate or truncate at the base, doubly serrate or lobed, somewhat scabrous. Fruit pyriform to short ellipsoid, red, somewhat cdible. Of considerable decorative value. Conn.-to Ont., I11., Del, and $\mathrm{Pa}$.

4.). Crataegus álbicans Ishe. Tatnall's Hawthorn A shrub or small tree with spreading branches. Leaves broadly ovate to oblong-ovatc, doubly serrate or lobed. Fruit subglobose or somewhat pyriform, dark red. Western $N$. Eng. to Mich., south to Del. and Tenn.

46. Crataegus arnoldiàna Sarg. Arnold's Hawthorn. A small tree with ascending branches, forming a broad crown. and numerous long thorns. Leaves broadly ovate to oval, serrate or doubly serrate with broad shallow lobes, tomentose or scabrous above. Fruit globose or subglobose, bright crimson, slightly pubescent; flesh thick, juicy, and edible. Mass. and Conn.

47. Crataegus submóllis Sarg. Enerson's Hawtlorn. A small tree with spreading branches, forming a broad symmetrical crown, and with numerous thorns. Leaves ovate. doubly serrate and acutely lobed, tomentose, becoming scabrate. Fruit short-ellipsoid to pyriform, orange-red, slightly tomentose, edible. Quebec to Mass. and $N$. Y.

4.. Crataegus mollis ( $T$. \& G.) Schecle. Downy Hawthorn. A tree with spreading branches and densely pubescent twigs, forming a broad-topped crown. Leaves broadly ovate, doubly serrate with narrow acute lobes, densely tomentose. Fruit short-ellipsoid to subglobose, scarlet, edible. Ont. to S. Dak., Tenn. and Ark.

40. Crataegus monógyna Jacy. Eng̨lish Hawthurn. A shrub or tree with ascending branches and numerous thorns. Leaves ovate, sharply 3-15 lobed or cleft, dark green and glabrous above when mature. Fruit globose or subglohose, red. Native of Europe. Sparingly escaped in the easteris states.

50. Crataegus uniflòra Mucuch. Dwarf llawtlurru. An irregular shrub or small tree with numerous, slender, 
straight thorns. Leaves obovate to spatulate, crenate or crenate-serrate, shining above. Corymbs 1-3 flowered. Fruit ellipsoid, pyriform or globose, greenish-yellow or red. In sandy soil. N. Y. to Fla., west to W. Va., Mo., and Tex.

i1. Crataegus douglásii Lindll. Douglas IIawthorn. A shrub or tree with dark brown scaly bark and short thorns. Leaves ovate to olovate, doubly serrate and lobed, dark green and pubescent above. Fruit short-ellipsoid, dark purple: flesh soft, sweet. From Mich. northwestward.

7.). Crataegus phaenópyrum (I.f.) Medic. Washing ton Hawthorn. A shrub or small tree with strongly ascending branches and numerous thorns. Leaves ovate-triangular, simply or doubly serrate, often 3-5 lobed, bright green and glabrous above. Fruit depressed-globose, scarlet. Moist rich ground. A very desirable species for cultivation. Va. to Ga., Ill., and Ark. Naturalized northward to N. J., Pa., and Ohio.

Amygdalatae. Peach Subfamily:

27. Prùnus (Tourn.) L. Apricot, Plum, Cherry.

Shrubs or trees with alternate, simple, serrate, pinnatelyveined leaves, with disk-like or tooth-like glands on the petiole: with stipules or stipular scars, cylindrical pith, twigs some shade of brown, and with the fruit a drupe.

Terminal bud present or self-pruned; perianth pentamerous; carpel 1, hypanthium deciduous; drupe mostly edible.

1. Terminal bud usually present; leaves conduplicate in vernation; stone globose, little or not at all flattened; inflorescence racemose, corymbose, or umbellate. ¿.

1. Terminal bud self-pruned; leaves convolute in vernation: stone of the drupe compressed; inflorescence umbellate or with only 1 or 2 flowers. 7 .

2. Petioles usually not over $\frac{1}{2}$ in. long; leaves ovate, abruptly acute at the apex; flowers corymbose, terminating twigs of the season. $P$. mahaleb.

2. Petioles usually an inch or more long, or if not, the leaves not ovate; flowers in umbellate or somewhat corymbose clusters, or in racemes. 3.

3. Flowers in umbellate or corymbose clusters. 1.

3. Flowers in racemes. 6. 
4. Leaves glabrous or nearly so. 5 .

4. Leaves pubescent beneath, at least on the veins, with prominent hairs; inflorescence umbellate; drupe sweet. P. arium.

$\therefore$ Leaves ovate-lanceolate to lanceolate; inflorescence more or less corymbose; drupe with thin sour flesh. $P$. pennsylíanica.

$\therefore$ Leaves nvate to ovate-lanceolate; inflorescence umbellate, drupe with thick sour flesh. P. cerasus.

i. Leaves oval-lanceolate to ovate, acuminate or acute; glands on the petiole usually elongated and tooth-like; lark black: drupe dark-purple or black, sweet. $P$. zirginiana.

i. I.eaves ohovate to oval, abruptly acute or acuminate; glands on the petiole usually rounded or disk-like: Tark gray; drupe red or purple, astringent. P. nana.

i. Leave's aloruptly acuminate, petiole much less than $\frac{1}{2}$ as long as the blade. 8.

7. Leaves abruptly long-acute or acuminate, ovate to roundwate: petiole ? as long as the blade; flowers solitary or in twos: fruit relvety. I'. armeniaca.

i. Leaves acute or obtusish, or gradually acuminate. 10.

\&. Leare's mostly broad and thick, somewhat pubescent or roughish leneath; calyx lohes pulescent or glabrous within. !9.

$\checkmark$ Leaves mostly narrow and peach-like, firm and more or less shining. glabrous; calyx loles punescent on both sidles. l'. liortulana.

1. (alyx-boles entire, pulescent within: fruit globose: flowers white. I'. americana.

!) Calyx loles glandular-serrate, glalorous within: iruit subglolose or oval: flowers white. turning pink. l'. nigra.

11. I.caves glabrous when mature, acute or acuminate. 11.

11. Leares puliescent leneath, neit pointed or only sliglutly so, ovate or olonate. P. domesticu.

11. Leaves lanceolate: drupe red with little or no bloom. P. angustifolia.

11. Leaves ovate, clrupe dark purple, with a hloom. I'. alli")hunionsis. 
Cherrics.

1. Prunus virginiàna I. Black Cherry. A large tree with rougl, black, flaky hark; drupe globose, dark-purple or black, sweet but slightly astringent. Leaves oval, ovallanceolate, or ovate, acuminate or acute, serrate with appressed teeth. Leaves very poisonous to cattle, especially when halfwilted. Kernels very poisonous. Wood rather heavy, hard. strong, of fine texture, of a brown or reddish color; much used in cabinct-work and interior finish, especially in cars and boats, also used in turnery. Self-prunes twigs by means of cleavage planes in basal joints. Ont. to Fla., N. Dak., Kan., Tex., and Ohio.

2. Prunus nàna Dı Roi. Choke Cherry. A shrub or small tree with gray bark. Leaves obovate or broadly oval, abruptly acute or acuminate at the apex, rounded at the nase, serrulate with slender teeth, glabrous or nearly so. Drupe, red to nearly black, sometimes yellow, very astringent, not edible. Leaves poisonous: kernels probably poisonous. Self-prunes leafy fruiting branches. Along river banks and in rocky places. Newf. to Man., Br. Col., Ga., Neb., Tex., Colo., and Ohio.

3. Prunus mahàleb I. Mahaleb Cherry. A small tree with pale smooth bark. Leaves ovate, abruptly acute at the apex, rounded or slightly cordate at the base, denticulate, glabrous, fragrant. Drupes with thin flesh and slightly flattened stone. From Europe. Conn. to Ont., N. Y. to Ohio and Kan.

i. Prunus Pennsylvánica I. f. Red Cherry. A small tree with sour globose, red drupes. Leaves oval or lanceolate. acute or acuminate, mainly rounded at the base, glabrous. serrulate. Leaves poisonous; kernels probably poisonous. In rocky woods. Newf, to Ga., west to Rocky Mts.

`. Prunus àvium I. Sweet Clierry. A medium-sized tree with globnse, Wlack or dark red, sweet, edible drupes. Leaves ovate, oval, or slightly obovate, abruptly short-acuminate, irregularly scrrate: Native of Europe. Ont. to Mass., Ohio and $\mathrm{V}$ a.

6. Prunus cérasus I. Sour Cherry. A small tree with glolose, red or redulish-black, sour, edible drupes. Leaves ovate or ovate-lanceolate, alıruptly acute or acuminate, 
rounded at the base, very resinous when young. Self-prunes the fruiting branchlets. Native of Europe. N. II. and Mass. to N. Y. and Ohio.

\section{Flums and Apricot.}

7. Prumus armeniaca L. Apricot. A small round-topped tree with redclish bark. Drupe nearly smooth. short stalked. yellow, edible. Cultivated.

$\therefore$ Prunus americàna Marsh. Wild Plum. I shrub or small trce with stunted thorn-like branches and thick black bark. Leaves ovate, or obovate sharply and often doubly serrate, rounded at the base, slender-petioled. Drupe with a tough shin, globose, red or yellowish, edihle. () ften used as a stock on which to graft domestic plums. Wood hard. reddish in color. $\mathrm{N}$. Y., to Mont., Fla., Colo., and Ohio.

9. Prunus nigra dit. Canada Plum. A tree with thin bark. Lcaves oval, ovate, or obovate, long-acuminate, crenulatc-serrate; drupe oval, orange-red, thick-skinned, with little or no bloon. Petals pink in age. Newf. to Man., Mass. and $\mathrm{W}$ is.

11. Prunus hortulàna Bail. Wild-goose Plum. A small tree with spreading branches and thin hark. Leaves ovate-lanceolate to orate, long-acuminate, closely glandularserrate. Drupe bright red and thin-skimned, edible. 111. to Kan., Tenn., and Tex.

11. Prunus angustifòlia Marsh. Chickasaw Plum. A small tree with thorn-like stunted branches. Leaves acute, serrulate, often rounded at the base. Drupe globose, red, and eclible. In dry soil. $\mathrm{N}$. J. to Fla., west to Rocky Mts.

1.). S'runus doméstica L. Common Garden Plum. A small tree with about 100 cultivated varicties. Drupe $1 \mathrm{f}$ various colors, covered with a thick glaucous bloom.

13. Prunus alleghaniénsis Port. Nlleghany Plum. A low shrul, or small tree, selelom thorny. Leaves acute or acuminate, finely serrate, rounded at the base. I)rupe pleasantly acid, globuse-oroid, with a conspicunus bloom. Penn.

\section{2). Amýgdalus 1. Peach.}

Trees or shrulos with altermate, simple, serrate, pimatelyreined leaves with 2-t disk-like glands at the alge of the 
lase of the blade, with terminal bud, stipular scars or stipules, reddish or greenish twigs, and velvety drupe.

Perianth pentamerous, carpel 1, hypanthium deciduous; irupe mostly cdible with a deeply pitted stone.

1. Amygdalus pérsica I. Peach. A small tree with beautiful pink or white flowers and a large edible drupe. Leaves with prominent nectar glands on the petiole or at the hase of the blade. Leaves and kernels bitter, poisonous. Native of Asia; abundantly escaped. N. Y. to Fla. and Kan.

$$
\begin{aligned}
& \text { Fabaceae. Pea Family. } \\
& \text { Cassiatae. Senna Subfamily. }
\end{aligned}
$$

\section{Cércis I. Rerlbud.}

Trees or shrubs with 2-ranked, entire, palmately veined leaves.

Flowers zygomorphic in short lateral fascicles; stamens 11), distinct; fruit a flat bean.

1. Cercis canadénsis $L$. Redbud. A small tree with l,right red-purple flowers before the leaves: fine for ornamental purposes. Whod hard and heavy, heautifully variegaterl. In rich soil. Easily cultivated. Ont. and $\mathrm{N}$. Y. to lowa. Neb., N. J., Fla., Tex.

\section{3n. Gledítsia I. Honey-locust.}

Trees with alternate, evenly pinnate or bipinnate leaves, superposed buds beneath the petiole hase, and uswally with liranched axillary thorns.

Flowers small, greenish, imperfectly monosporangiate and diecious: fruit a bean.

1. Pod lincar-oblong, many seeded, pulpy within: leaflets short stalked, oblong-lanceolate or oval, olstuse at both ends, inequilateral at the base. G. triacanthos.

1. Pod obliquely rval, 1-secled, not pulpy; leaflets thicker. darker green, usually larger, ovate-lanceolate or lanceolate, the margin more crenulate. G. aquatica.

1. Gleditsia triacánthos L. Honey-locust. A large tree of rapid growth, ustally with stout branching or simple thorns and with rough bark, the catkin-like racemes often 
appearing on the main trumk and larger liranches. U'sed as a hedge plant. Intumu leaves pure yellow. Hood heary. liard. strong and tough: used for fencing, fuel and wagon hubs. Spronts freely from the roots if disturbed by plowing Grows well in dry or sandy soil. Ont. and X. Y. to S. 1)ak.. (ia., Kan., and Tex.

-). Gleditsia aquática Marsh. Water Honey-lucust. A tree growing in swamps. Thorns usually little branched. Wood very hard and bright reddish-brown. Ind. to Mo., S. (ar., lila., and Texas.

\section{:31. Gymnócladus I.am. Coffee-bean.}

Trees with alternate. evenly bipinnate leaves, sunken superposed axillary buds, and large chocolate-colored pith.

Flowers greenish, diecious, both types with vestages of the opposite sporophylls: fruit a woody bean.

1. Gymnocladus dioica (I.) Koch. Coffee-bean. I large, slow-growing tree with rough bark and few branches. Bean short and thick, the greenish pulp within poisonous. The bruised leaves are used as a fly poison, and the seeds have been used as a substitute for coffee. Wood compact. heavy, rather soft, strong, tough, reddish in color, or coarse texture, and taking a good polish; used to some extent in cabinct-work. In rich soil. Ont. to Ohio and Penn., Tenn.. S. Dak., and Okla.

\section{Fabatac. Pea Sụbfamils.}

\section{:3.). Cladrástis Raf. Jellow-Wool.}

Trees with alternate, odd-pinnate leaves with entire leatlets, with the petiole base covering the superposed buds, and without milky or resimous sap.

Flowers white, showy, fragrant: fruit a slender bean.

1. Cladrastis lùtea (Mx. f.) Koch. Anerican Vellow wood. Trees with smooth bark, close like in the beech. Wood light-yellow. In rich soil; much planted. Ky.. Mo., Tenn., and N. Car. 


\section{Robínia L. Locust.}

Trees or shrubs with alternate odd-pinnate non-punctate leaves and with stipular spines.

flowers showy, in racemes: fruit a Hat hean.

1. Twigs, petioles and pods glabrous or nearly so: Howers white. R. pseudoacaiti.

1. Twigs and petioles glandular; pods hispid: flowers pinkish. R. riscosa.

1. Robinia pseudoacàcia L. Common Locust. A large slender tree with very rough bark, of rapid growth. Wood very heary, hard, strong, tough, valuable, and very. lurable in contact with the ground; used for posts, railroad ties, wagon hubs, furniture, and in ship building. All parts of the plant very poisonous. It is troublesome from sprouting from the rots. Penn. and Ohio to Ga., Iowa, Kan., and Okla.

-. Robinia viscòsa Vent. Clammy Locust. A small tree with rough bark. Underground parts somewhat poisonous. Wood hrown, the sap-wood yellow. Va. to Ga. Also escaped in Middle and Eastern States.

()rder. Celastralfs.

Rhamnaceac. Buckthorn Family.

34. Rhámnus (Tourn.) L. Buckthorn.

Shrul)s or small trees with alternate, rarely opposite, simple serrate or minutely serrulate leaves, and with berry-like drupes containing $2-1$ stones.

Flowers bisporangiate or diecious or imperfectly monosporangiate, small, in small axillary clusters. Twigs sor. $€-$ times ending in stout thorns.

1. Leaves acute, with $6-10$ pairs of lateral veins: nutlets smooth: umbels peduncled: flowers bisporanziate. $R$. caroliniana.

1. Leaves with 3 or 4 pairs of lateral veins, the basal pair prominent; nutlets of the fruit grooved; flowers diecious or imperfectly monosporangiate. R. cathartica. 
1. Rhamnus caroliniàna Walt. Carolina Buckthorn. id tall thornless shrub or small tree with a glohose sweet drupe. In wet soil. Va. and Ohio to Kan., lila., and Tex.

․ Rhamnus cathàrtica L. Common Buckthorn. A shrub or small tree with hlack injurious fruit. Somewhat thorny and used for hedges. Thic fruit yields a dye and has powerful medicinal properties. Introduced from Europe. Eastern states.

Celastraceae. Stafftree Family:

ii.) Euónymus (Tourn.) L. Wahon

Shrubs or small trees with opposite, simple, pinnately veined, serrate leaves, green twigs and central bundle-scars.

Flowers regular, small; fruit a 3-5-locular dehiscent capsule: seeds enclosed in a red aril.

1. Flowers purple; cymes 6-15 Howered; winter buds longpointed with long bud scales. E. atropurpureus.

1. Flowers greenish yellow; cymes $3-\bar{T}$ flowered; winter buds very short pointed with short bud scales. $E$. curopacus.

1. Euonymus atropurpùreus Jacq. WVahoo. A high shrub or small tree with green, obtusely t-angled twigs. Leaves dark red and fruit very ornamental in autumn. Selfprunes small twigs by basal joints. Wood nearly white. Ont. to Fla., Mont. and Okla.

2. Euonymus europàeus 1. Spindletrec. A shrul, or simall tree resembling the preceling. Self-prunes twigs. Cultivated from Europe. Escaped. N. I.. N. J. and Va.

\section{Jlicaceae. Holly lamily.}

:3i. 'Ilex I. Holly.

Shrubs or trees with alternate, not two-ranked, simple, pimately veined, serrate or lobed leaves which are sometimes evergreen; with watery sap; anad with herry-like drupes containing several small stones.

lilowers small, in axillary clusters or solitary mostly imperfectly diecions. 
1. Ieaves thick, persistent, evergreen, spiny. I. opaca.

1. Leaves thin, deciduous, not spiny. 2.

$\therefore$ Leaves small, obovate or spatulate, crenate: nutlets of the fruit ribbed: I. decidua.

.. Leaves large, ovate or lancenlate, sharply serrate, mutlet. ribbed. I. montana.

1. Ilex decídua Walt. Deciduous Holly. A slirub or small tree with light-gray, glabrous twigs and red drupes. Wood hard and white. In swamps and low ground. D. C. to Fla.. Kan., and Tex.

-). Ilex montana (T. \& G.) Gr. Mountain Holly. I shrub or slender, erect tree growing in mountain woods. Drupes red. $N$. Y. to Ga., and Ala.

$\therefore$ Ilex opàca Ait. American Holly. A tree of slow growth with thick, glabrous, evergreen leaves and globose red or rarely yellow drupes. Twigs with leaves and fruit much used for Christmas decoration. Wood very white. fine-grained, hard, strong, tough, light in weight, and easily: worked; used for cabinet-work and in turnery. Bird-lime is prepared from the mirldle bark. In moist soil. Should be much planted for ormament in suitable places. The leaves should be cut off when transplanted. Me. to Fla., Penun, Mu.. and Tex.

Staphyleaceac. Bladdernut Family.

:37. Staphylèa L. Bladdernut.

Shrubs or small trees with opposite trifoliate serrate leaves.

Stipules caducous; Howers in axillary racemes or panicles. white, hisporangiate, regular: capsule large and bladdery. triocular.

1. Staphylea trifòlia L. American Bladdermut. A shrub or rarely small tree with smooth striped bark. Branching a sympodial dichotomy. In moist soil. Quebec to $H_{\text {inn., }}$ S. Car., and Kan. 
()rder, S.IPINu.ıl.Es.

Sapindaceac. Soapberry Family.

38. Sapíndus (Tourn.) I. Soapberry.

Trees or shrulos with alternate, odd-pinnate leaves, with entire, inequilateral, acuminate leaflets, and with solid pith; with axillary, exposed, superposed buds: and without stipular spines.

lilowers imperfectly diccions; fruit a 1-3-seeded berry:

1. Sapindus drummóndii H \& A. Drummond Soapberry. A tree with white flowers in dense terminal panicles and very saponaceous, globose herries. Wood hard, light yellowish brown: used in Texas for cotton baskets. Kan. and Mo. to La. and Ariz.

\section{Koelreutèria Laxm.}

Trees with alternate, odd-pinnate or bipinnate leaves with the leaflets toothed and usually more or less cut and lohed: without prickles, stipules, or terminal buds, hut with numerous scattered bundle-scars and large cylindrical pith.

Flowers yellow, diecious, in large terminal panicles: fruit a trilocular bladdery capsule: outer bud-scales :-

1. Koelreuteria paniculata Laxm. Chinese V'arnishtree. A tree much planted for ormament. Reported as spontaneous from seed in Indiana.

Aesculaceac. Buckeye Family.

411. Aésculus I. Buckeye, Horse-chestnut.

Trees or shruhs with opposite palmately compound leaves.

Flowers imperfectly monosporangiate, zygomorphic, in terminal panicles; capsules leathery, containing large shining nut-like seeds.

1. Flowers white, mottled with yellow and purple: leaflets abruptly acuminate; winter buds gummy: capsule spiny; bundle scars arranged in a curverl line. A. hippocastanum.

1. lilowers yellow or purplish; leaflets acuminate, more or less abrupt: winter buds not gummy: bundle scars arranged in 3 areas. ". 
-. Capsule spiny, stamens exserted. 3.

$\therefore$ Capsule glabrons; stamens not longer than the petals. corolla yellow or purplish. A. octandra.

3. Leallets acuminate, finely serrate, $\mathbf{5 - 7}$; a tree. 1 . ylabra.

:3. I.eaflets long-acuminate, mnequally serrate, $7-9$; a shrul-like small tree. A. arguta.

1. Aesculus hippocástanum L. Horse-chestnut. I large tree with very resinous, gummy winter buds. Antumm leaves orange. The seeds are poisonous and symptoms of poisoning have been produced from eating the green rind. The twigs contain Aesculin which is flurescent in adueous sulution. Escaperl from cultivation: native of Asia.

.. Aesculus glàbra Willd. Ohio Buckeye. I large tree with rongl and feticl hark. Leaves, young shoots, and seeds poisonous to cattle. Wood light and hard to split: used for making artificial limbs, wooden-ware, and paper pulp. Penn., to Ala., Mich., Neb., and Okla.

$\therefore$ Aesculus argùta Buckl. Western Buckeye. I shruh-like small tree with smooth hark. On flood plains. Mo. and Kan. to Texas. Reported from Iowa.

4. Aesculus octándra Marsh. Yellow Bnckeyc. I large tree with brown scaly bark. Sceds poisonous. IVood light and hard to split; used for making artificial limbs, woodenware, and paper pulp. Aesculus octandra hybrida (I) (․) Sarg. has purplish or pink llowers, leaflets pulsescent lieneath. and light brown hark. P'enn. to (ia., Lowa and Tex.

\section{Iceraceac. Maple liamily.}

\section{1. Àcer (Tourn.) L. Maple.}

Trees or shrulos with opposite leaves, with :3-; bundle scars in the narrow, contigu us leaf scars, and with a terminal hud showing several pairs of visible scales.

Sap watery or sometine's milky, often saccharine: fruit a ¿-winged samara. Usually diecious or imperfectly diecious.

1. Leaves pinnate or trifoliate: twigs green, glancous. A. negundo.

1. Leaves simple. 2. 
$\therefore$ Leaves with very large teeth of loles, the divisions not serrate or serrate-dentate. :3.

-. Leaves with the large divisions or lohes serrate or serrate-dentate. J.

3. Leaves with stipules which are often large and foliaceous: leaves green and pubescent beneath at least on the veins: flowers corymbose, unfolding with the leaves; wings of fruit diverging a little less than a right angle. 1 . nigrum.

:3. Leaves without stipules. 4 .

1. Leaves with much milky sap in the petiole, glabrous. dark green above, lighter below, usually with 7 prominent palmate veins: flowers corymbose, unfolding with the leaves; wings of the fruit diverging nearly in a straight line: petals present: winter huds rounded. .t. platanoides.

t. Leaves with watery or frothy sap, pale and nearly glabrous beneath, usually with i prominent palmate veins; flowers corymbose, unfolding with the leaves: wings of the fruit diverging a little less than a right angle: petals none: winter burk pointed. A. saccharum.

i. Leaves very sharply and tinely serrate, :-lohed at the outer end, widest above the middle, the lobes abruptly narrow-acuminate, brown pubescent below when young: twigs green, striped with darker lines: flowers racemed, terminal, unfolding after the leaves. 1. pennsylíanicum.

$\therefore$ Leaves dentate-serrate or lobed, not abruptly narrowacuminate: twigs not striped. li.

i. Leaves broadly :--i-lohed, the lobes rather rezularl: and continuously dentate-serrate or dentate-crenate: Howers recemed, terminal. minfolding after the leaves. $\bar{\imath}$.

i. Leaves ustuall, with $3-\bar{\tau}$ slender, lung and pointed lobes, the lubes irregularly or interruptedly serrate or serrate-cientate: Howers in dense sessile lateral clusters, ap,earing before the leaves. \&. 
7. I.eaves longer than wide, slightly 3-lobed at the outer end, usually only very slightly lobed at the lower end, not glaucous below: hark of twigs green w grayish; racemes erect: a shruh, rarely a small tree. A. spicatum.

7. Leaves as broad or broader than long. prominently -i-lobed, glabrous and dark green ahove, pulsescent and light glaucous below, on long reddish petioles: bark of twigs reddish-brown: racentes drooping: wings of fruit pubescent, moderately spreading: a large tree. \% pscudo-platanus.

$\therefore$ Leaves usually deeply i-lobed, lobes slender, acute. white and glatcons beneath; notches between the lolses often somewhat rounded: fruiting pedicel short and stiff, 1-2 in. long: wings divergent: petals none. 4. suciharinum.

₹. Leaves sharply: 3-; lobed, whitish glaticous beneath. notches acute: fruiting pedicel long. slender and drooping, 2-4 in. long: wings incurved: petals present. 4. rubrum.

1. Acer platanoides L. Norway Maple. I mediumsized tree with a broad rounded crown, with brown twigs and milky sap. Leaves sharply i-i lohed, very dark green above. Much cultivated.

-. Acer pseudo-plátanus L. Sycamore Maple. A line tree with spreading l,ranches. Leaves deeply :3-5 loherl. Selfprunes. Much cultivated.

$\therefore$ Acer pennsylvànicum $\mathrm{I}$. Sitriperl Maple. 1 small tree with smoothish green loark striped with darker lines. Leaves broadest above the middle, thin, glabrous above slightly pubescent beneath when young, truncate or somewhat cordate at the hase, 3-lohed near the apex. Wood white and soft. In rocky soil. N. S. to Lake Superior, and along the mountains to Cia. and Temn.

t. Acer spicàtum Lam. Mountain Maple. I shrul) wr small tree, the loark green but not striped. Leaves :3-, ilobed, the lobes acute or acuminate, glabrous above, pulsescent heneath at least when young. In damp rocky wools. Newf. to Man., south to X. Car., Tenn., Minn!., and Inwa. 
$\therefore$ Acer sáccharum Marsh. Sugar Maple. I large tree with yellow or sometimes red leaves in autumm. Leaves curdate or truncate at the base, 3-7 lobed, the lobes acuminate. irregularly sinuate, dark green above, pale and nearly glabrous herieath. Its sall is the main source of maple sugar and syrup. In arerage tree will yield $2-111$ lbs. of sugar a season. I line shacle tree. The ashes give large quantities of potash. IVood heavy, hard, strong and tough: used for fuel, interior linish, furniture, keels of boats and ships, implements and machinery, stuclier rods, rims of bicycle wheels, piano action. school apparatus, large wood type, tool and broom handles, and wood carving. Newf. to Man., south to Fla. and Tex.

(1) Acer nigrum $11 x$. Black Maple. I large fine tree with rough blackish bark. Leaves cordate or truncate at the liase, 3-i-lobed, the lobes broad and short, green on both sides. generally more or less pubescent beneath. It is equally valuable for the making of sugar. Wood much the same as in the Sugar Maple, and used for the same purposes. Ont. and Vt. to Ga., S. Dak., La. and Ark.

7. Acer rùbrum 1. Red Maple. A tree with tlaky or smouthish bark and reddish twigs. Leaves sharply :3-5-lobed. the lohes irregularly dentate, acute or acmminate, cordate at the base, green ahove, whitish beneath. Wood of considerable value when it shows a "curly grain." Leaves crimson, scarlet or yellow in autumn. Self-pruning like the preceding. In swanns and low ground, also on moist hillsides. X. S. to Man., Fla., Nel., and Tex.

$\therefore$ Acer sacchárinum I. Silver Maple. I large tree with iaky hark, the twigs often reddish, self-pruned hy basal joints. leaves deeply i-lobed, the lobes rather narrow. acuminate, coarsely and irregularly dentate, truncate or slightly cordate at the hase, green above, silvery white and more or less pulescent beneath. A fine shade tree and much planted. Wood soft and white: used for furniture. Yields a small amount of sugar. Along streams. N. B. to Fla., Ont., S. Dak., Neb. and Okla.

!) Acer negúndo L. Boxelder. A small tree with spreading branches and glabrous, sometimes pubescent, green and glaucous twigs. leaves $3-7$ foliate, leaflets ovate or oval. The sap produces a slight amount of sugar. Wood light 
and of slight value. Mlong streams. Planted on the prairies for small groves and wind hreaks. Maine to Man.. Fla., Kan. and Mex.

Anacurdiacial. Sumac family:

4.). Rhús (Tourn.) L. Sumac.

Small trees or shrubs with alternate pinnately compound leaves, with sticky milky or resinous sap, and pubescent drupes.

Flowers in panicles, imperfectly hisporangiate, small; stamens live, styles three: drupe red.

1. Petioles not completely covering the axillary buds; leaflets cntire: rachis of the leaf wing-margined; leaflets $7-31$ : twigs and the red drupes pubescent. R. copallina.

1. Petioles covering the axillary bucls; leaflets serrate. 2).

.). Leaves and twigs velvety-puhescent. R. hirta.

$\stackrel{2}{2}$ Leaves and twigs glabrous, somewhat glaucous. $R$. glabra.

1. Rhus copallina L. Nountain Sumac. A slrub or small tree with a dense terminal panicle of small globose, crimson drupes, covered with short acid hairs. Leaves used for tanning purposes. Wood soft and light brown. In dry soil. Me, and Ont. to Fla., Minn.. Neb. and Tex.

2. Rhus hirta (L.) Sudw. Staghorn Sumac. A small tree or shrul, with red, pubescent drupes. Wood very soft and hrittle. In dry or rocky soil. I good lemonade or "sumacade" is made by steeping the drupes and sweetening to taste. Leaves used for tanning. Wood soft, greenishyellow. N. S. to Ga., Ont., S. Dak., Mo. and Iowa.

$\therefore$ Rhus glàbra L. Smooth Sumac. A shrub or small tree with dense panicles of small crimson drupes covered with short acid hairs. Noted for its beautiful, brilliant, red-colored leaves in autumn. Leaves used for tanning. Common on hillsicles and bluffs. N. S. to Minn., Fla.. Miss. and La 


\title{
13. Toxicodéndron. L'sison-Simatc.
}

small trees or shrubs, onrs with alternate pinnate leaves with entire leaflets, with poisonous resinous saj), and with glabrous or slightly pubescent drupes.

Flowers small, in axillary panicles, imperfectly bisporangiate: drupes gray or white.

1. Toxicodendron vérnix (L.) Ktz. Poison Sumac. I shrul, or small tree, very poisonous to the totich. 1)rupes gray, glabrous, in loose axillary panicles. In swamps and wet places. Wood soft, yellowish brown, poisoncus. Waine to Fla., ()nt., Minn., Mo. and La.

\section{Cótinus Irlans. Smoketree.}

Small trees or shrubs with alternate, simple pinnately vined, entire, deciduous leaves and fragrant resinous sap.

Flowers small, imperfectly bisporangiate, on a large terminal panicle: stamens i, styles :3, lateral: drupe oblique, small, compressed; huds clustered at the tip of the twig.

1. Blade of the leaf slightly decurrent on the petiole. thin, glabrous or slightly pubescent beneatli. $C$. americanus.

1. Leaves mostly rounded or olutuse at the base, coriaceous, more pubescent. C. cotimus.

1. Cotinus americànus Nutt. Imerican Smoketrec. I small wille-loranched tree. Wood soft, orange-yellow, yielding a rich dye. Mo. and Okla. to Temn, and Ala.

¿. Cotinus cotinus (l.) Sarg. European Smoketrec. small irce, native of Furope, frecpently cultivated.

\author{
Suluclass, Amextreks.te. \\ Order, Pintakil.ks. \\ Hamamelidacose. Witch-hazel Family. \\ Sulsamily, Hamamelidatac.
}

\section{1.). Hamamèlis 1. Witch-liazel.}

Shrulss or small trees with 2 -ranked, simple, ineyuilateral, straight-veined leave's and stalked axillary buds.

folowers bisporangiate or inperfectly lisporangiate, in axillary clusters; fruit a hilocular, woonly or cartilaginous. nut-like capsule. 
1. Hamamelis virginiàna L. Witch-hakel. I shrul, wr small tree with -)-ranked leaves and stalked buds. Blooms in late autumn. Wood hard. In fow ground and o lo hanks. N. B. and $\mathrm{N}$. S. to Minn., Yo., Fla. and Tex.

\section{Subfamily, Altingiatue.}

\section{he. Liquidámbar I. Sweet-gum!.}

Trees with alternate, simple, palmately veined, fragrant, star-shaped, serrate leaves and i-angled pith.

Sap resinous, aromatic: Howers monecious, in liearls, the staminate clusters racemose: capsules in a lense spiny ghol)ular head.

1. Liquidambar styraciflua I. Sweet-gum. I fine large tree with wide spreading branches, the twigs often covered with corky ridges. Leaves with a peculiar sweet fragrance when crushed. Autumn leaves red, yellow, and brown. Wood valuable, of medium weight, hard, not strong, tough, and of hine texture, reddish brown, difficult to season. Sometimes used as a substitute for black walnut. Used for furniture, veneer, wooden plates, plaques, baskets, hat blocks and wagon hubs. In low ground. Comm., N. Y. and Ohio to Fla., I11., Mo., and Mex.

\section{Platanaceac. Planetree Family:}

\section{Plátanus (Tourn.) L. Planetrec.}

Large trees with alternate simple leaves having the base of the petiole cover the axillary bud and with complete stipular rings.

Terminal bud self-prunce; flowers in spherical heads. monecions, without perianth; fruit in pendant spherical hearls composed of numerous small nutlets.

1. Park exfoliating in small plates: leaves i-angled only slightly 3-lohed, or seldom slightly is-lobed. I' occidentalis.

1. Bark exfoliating in large plates: leaves somewhat iloled, in some rarieties deeply lobed. I'. oriontalis.

1. Platanus occidentàlis L. Sycamore. A very large tree, the largest in the nurtheastern United States, with whitish or green bark which peels off freely in thin plates: 
the largest trunkis nsually hollow, sometimes as much as t.2 ft. in circumference. Intumm leaves brown. Wood rather hard, compact, coarse-grained, difficult to split, tough, and of a light-brown color; used for tobacco boxes, cooperage, cabinct-work, and finishing lumber. Along the banks of streams and in moist ground but grows well in ordinary mesophytic conditions. Me. to Ont. and Minn., Fla., Kan. and Tex.

$\because$ I'lutunns oricutalis L. Oriental Planetree. A large see much like the preceding, but usually with a comparatively short, massive trumk and a hroad round crown. Leaves more cut and lecoming smooth earlier. ()casionally planted. From Western Asia and Eastern Europe.

()riler, LiRTIC:ILES.

l'Inaceac. Elm Family.

\section{R. Úlmus ('Tomrı.) L. Elm.}

Trees with alternate, E-ranked, pinnately straight-veined, incouilateral. doubly serrate leaves and sessile axillary buds.

lilowers hisporangiate or imperfectly hisporangiate. in clusters or racemes: fruit a samara: trees of rapid growtl.

1. Leaves very romgh above: twigs not corky-winged and not self-pruned, but large numbers of lateral inuls cut off: imer bark sometimes mucilagious. 2 .

1. Leares smootl or sometimes somewhat rough alupe. 3.

2. Inner hark very mucilaginous, buds rusty-downy, samara much less than I in. long. I' fulitu.

ב. Imner hark not mucilaginous, huds not downy, samaras I ill. long. L'. montana.

:3. Vunc of the branches corky-winged; twigs smooth. seli-pruned hy hasal joints and by cleavage planes in the nodes of ammual growth: samara faces slabrous. U. americuna.

:3. None of the branches with corliy ridges: twigs glahrous or nearly so, not self-pruned; samara glalofous or nearly so, deeply notched. $l$. compestris.

i. Some or all of the liranches corky-winged. or twigs pulurmlent, self-prumed : samara-faces puleseent. I. 
1. Mest of the branches with corky wing-like ridges: twigs glabrous or ncarly so: leaves $1-3$ in. long. I. alata.

t. Branches often with corky wing-like ridges; twigs puberulent: leaves 2-.; in. long. U. thomasi.

1. Ulmus americàna 1 . White Elm. A large tree of rapid growth, with the hark in thick, rough ridges: much cultivated in cities and along roadsides. Trunks up to $3: 3 \mathrm{ft}$. in circumference. Samara ovate-oval, its faces glabrous. Wood heavy, hard, flexible, and very tough: used for wheellublos, saddle-trees. rough cooperage and furniture, in boat and ship building. in the construction of cars and wagons, and especially for harrel hoops. Common on bluffs and on the flood plains of rivers and creeks. Craceful in form and very suitable for cultivation. Newf. to Man., Fla. and Tex.

.. Ulmus thómasi Sarg. Cork Elm. A large tree with puberulent young twigs, the branches or some of them with corky wings. Samara oval, its margins densely ciliate. Wocd harder, stronger, and more durable than that of the White Elm. In rich soil. Quehec to Ont., Minn., Kỵ., Nels. and Mo.

3. Ulmus alàta $M x$. Winged Elm. A small tree, hranches usually with corky wing-like ridges; twigs glabrous or nearly so. Samara oblong, pubescent on the faces. Wood very compact: used for wheel hubs. In dry or moist soil. $V$ a. to Fila., I11., Mo. and Tex.

4. Clmus campéstris L. linglish Elm. A tree, rather pyramidal in shape, the twigs asconding, not drooping except in "weeping" forms. Samara not ciliate. nearly or quite glabrous. A good timber tree. Cultivated, from Europe.

.) Ulmus fúlva $\mathrm{Xx}$. Slippery Elm. A medium-sized tree with rough grayish-brown fragrant bark and rough-puhescent twigs. Samara oval-orbicular, pubescent over the seerl. Inner bark mucilaginous and medicinal. Wcod hard and strong hut splitting easily when dry. Alone streams, on Anod plains and on hills. Quehee to X. Mak., Fla. and Tex

ti. Clmus montana With. Scotch Elm. A large tree with sprearling liranches. or in some varietics with strictly 
11pright branches; hranchlets pubescent. leaves rough above, pulesent beneath, doubly serrate, of ten somewhat :3-lobed at the apex. Many varieties fine for planting. From Europe.

\section{Plánera Gmel. Planertrec.}

Trees with alternate, two-ranked, straight-veined, inequilateral, scrrate leaves and with bark scaling off in plates.

Trees similar to the elms but with a nut-like fruit and the Howers expanding with the leaves.

1. Planera aquática (WValt.) (imel. Planertree. A small tree with nearly glabrous leaves growing in swamps and on wet banks. Wood compact, soft, weak, light hrown. Incl. to Mo., Ky., N. Car., Iila. and Tex.

iil. Céltis (Tourn.) L. Hackberry.

Trees or shrubs with -ranked, simple, leaves with two prominent lateral veins from the base and with interruptedly diaphragmed pith with cavities.

Flowers in the axils of leaves, on short branches: fruit an ovoid or globose drupe.

1. Leaves sharply serrate; smooth or scabrous above: twigs glabrous, especially the fruiting ones, or pubescent. C. occidentalis.

1. Leaves entire or few-toothed, small. (' " mississippiensis.

1. Celtis occidentàlis 1. Common Hackberry. I medium-sized tree with rough bark. Commonly much distorted with "witches brooms." Drupe sweet and edible. Self-prunes the fruiting twigs in winter. Wood heavy, hard, strong, quite tough, greenish-white. In dry soil and on flood plains. Quebec to Man., N. Car., Mo., Kan. and Okla.

-. Celtis mississippiénsis linsc. Southern llacklerry A medium-sized tree with light gray, rough bark. Usually in dry soil. Va. to 111., Mo., Kan.. Fla., and Tex. 


\section{Moraceae. Nulberry lamily. Subfamily, Moratac.}

\section{il. Mòrus (Tourn.) L. Mulberry.}

Trees or shrubs with alternate, simple, 2-ranked leaves "ith two prominent side ribs from the base, with milky sap, and with glabrous or pubescent but not downy twigs.

Flowers monosporangiate; fruit aggregate, berry-like.

1. Leaves scabrous above, pubescent beneath. M. rubra.

1. Leaves smooth and glabrous on both sides, or nearly so. M. alba.

1. Morus rùbra L. Red Mulberry. A small, monecious or diecious tree with rough gray bark, separating in strips. Fruit dark purple-red, edible, delicious. Wood rather heavy, hard, strong, and rather tough; very durable in contact with the ground, very valuable for posts; used for farm implements, in cooperage, "acid wood," and ship building. In rich soil Vt. and Ont. to Mich., S. Dak., Fla. and Tex.

‥ Morus álba L. White Mulberry. A small rapidgrowing tree with rough light gray bark and spreading branches. Fruit edible but usually rather insipid. Leaves used for feeding silk-worms. Wood suitable for posts. Although growing best in rich moist soil, it does well in quite dry regions and should be much planted on the dry prairies, especially varieties with the better grade of berries. Introduced from the old world. Me. and Ont.. to Fla. and Kan.

\section{i.). Tóxylon Raf. ()sage-orange.}

Small trees with alternate simple entire leaves, typical axillary thorns, and milky sap.

Flowers diecious, the staminate racemose, the carpellate capitate; fruit a large spherical, greenish or yellowing aggregate.

1. Toxylon pomíferum Raf. Osage-orange. A small thorny tree much planted for hedges. Leares ovate to ovatelanccolate, acuminate or taper-pointed. Wood very heavy, exceedingly hard, and strong, but not tough, brownish-yellow; valuable for fence posts and fire woor, also for wagon making. The thorns produce painful womds. Iforses 
acquire a strong liking for the young shoots and eat them in large quantities without apparent ill effects. Mo. and Kan. to Tex. Escaped in Ohio and other eastern states.

\section{Papýrius Lam. Paper-mulberry.}

Trees with alternate simple 2-ranked leaves having two prominent side-ribs from the base, with milky sap, and with downy twigs.

Flowers diecious, the staminate in ament-like spikes, the carpellate capitate; fruit a globular head of red drupes.

1. Papyrius papyrífera (L.) Ktz. Paper-mulherry A small, low-branching, large-headed tree with dark scarlet fruit which is sweet but insipid. Native of eastern Asia. In Japan and China the bark is made into paper. Escaped from cultivation. N. Y. to Ga., and Mo.

\section{Order, Fagales,}

Fagaceae. Beech Family.

\section{Fàgus (Tourn.) L. Beech.}

Large trees with alternate 2-ranked simple equilateral pinnately straight-veined dentate leaves, with a vein for each troth, and with prominent green medullary rays.

Winter buds usually very long-pointed; flowers monecious : nut 3-angled, enclosed in a 4-valved bur with soft, short prickles.

1. Fagus grandifòlia Ehrh. American Beech. I large tree, the lower branches spreading. Autumn leaves pure yellow. Nut sweet and edible. Wood hard, heavy, lightcolored, rather close-grained, not durable in the ground; used for making chairs, handles, plane-stocks, shoe-lasts, in turiery, and for "acid wood." In rich but not necessarily deep soil. N. S. to Ont. and Minn., Mo., Fla., and Tex.

\section{j.). Castànea (Tourn.) Hill. Chestuut.}

Trees or shrubs with simple alternate equilateral pinnately straight-veined serrate leaves, with a vein for each tooth, with ó-angled pith and inconspicuous medullary rays.

Flowers monecious; fruit a rounded coriaceous 11ut; several in a globose, mostly 4 -valved involucre covered with long prickles. 
1. Leaves green on both sides; large trees. C. dentata.

1. Leaves densely white-tomentose beneath; shrubs or small trees. C. pumila.

Castanea dentàta (Marsh.) Borkh. Chestnut. A large tree of very rapid growth with rough bark in longitudinal ridges. Nut sweet and edible. Wood soft, light, and coarse-grained, durable; used for cabinet-work, railway ties, posts, cooperage, "acid wood," and telegraph poles. Sprouts freely from stumps. In rich gravelly or sandy soil. Me. to Mich., Ga., and Ark.

๖. Castanea pùmila (I..) Mill. Chinquapin. A shrul) or small tree. Nut very sweet. Wood much like in C. dentata but heavier. In dry soil. N. J. to Ind., Mo., Fla., and Tex.

\section{Quércus (Tourn.) L. Oak.}

Trees or shrubs with simple alternate leaves, not 2ranked; with 5-angled pith; buds clustered at the tip of the twig; and with scattered bundle-scars.

Fiowers monecious, the staminate in slender aments: fruit a 1-seeded coriaceous nut (acorn) in an involucrate cup.

1. Leaves not bristle-tipped: acorns maturing the first year. 2.

1. Leaves with bristle-tips; acorns maturing in the autumn of the second year. 11 .

-) Leaves creinate or dentate, not lobed. 3.

2. Leaves pinnatified or pinnately lobed. $\tau$.

$\therefore$ Fruits not on a peduncle, nearly sessile, teeth or shallow lobes of the leares acute. $t$.

$\therefore$ Fruits on a peduncle: teeth or shallow lobes of the leaves rounded. is.

1. Tall trees, leaves oblong, ohovate or lanceolate. $Q$. muhlenbergii.

4. Slirub or low tree, leaves ohovate or oval; seed edible. Q. prinoides.

.) Peduncle as long or shorter than the petioles; leaves gray-tomentulose beneath. 6 .

¡. Peduncle much longer than the petioles; leaves whitetomentulose heneath. $Q$. bicolor. 
(i. Teeth of the leaves acute or mucronulate; bark white, flaky; seed sweet and edible; fruit short peduncled or sometimes nearly sessile. Q. michauxii.

(i. Teeth of the leaves rounded; bark close; seed edible; petioles slender; peduncles equalling or shorter than the petioles. $Q$. prinus.

7. Mature leaves pale, or glaucous and glabrous below. 8 .

7. Mature leaves pubescent or tomentose below, lyrate-pinnatificl. 9 .

․ Bark separating in thin scales, light gray or light brown; cup shallow; hracts thick and warty. Q. alba.

8. Bark furrowed and ridged, not scaly, dark gray or dark brown; cup hemispherical, with imbricated, appressed scales; cultivated in many varieties. Q. robur.

!. Leaves pubescent beneath, oblong-obovate, usually 5lobed, stellate-pubescent above; upper scales of the cup not awned. Q. stcllata.

9. Leaves white-tomentulose beneath. 10 .

10. Leaves obovate or oblong, lyrate pinnatifid or deeply sinuate-lobed; upper scales awned, forming a fringe around the acorn. Q. macrocarpa.

10. Leaves obovate-oblong, deeply 5-9-lobed; acorn often nearly enclosed in the cup, the upper scales not awned. Q. lyrata.

11. Leaves entire, oblong, linear-oblong or lanceolate. 12.

11. Leaves 3-5 lobed above the middle, or entire, obovate or spatulate in outline. $1 \%$.

11. Leaves pinnatifid or pinnately lobed. 14 .

1.2. Leaves oblong or lanceolate, tomentulose beneath. $Q$. imbricaria.

12. Leaves linear-oblong, green and glabrous on both sides. Q. phellos.

13. Leaves spatulate, glabrous on both sides; cup saucershaped, acorn globose-ovoid. Q. nigra.

13. Leaves obovate-cuneate, brown-floccose beneath; cup deep, acorn ovoid. Q. marylandica.

14. Leaves white or gray-tomentose below. 1\%.

1. Leaves green on both sides. 17.

15. Leaf-lobes lanceolate or linear-lanceolate, long; large trees. 16 . 
1.) 1.eaf-lobes triansular-ovate, short: slirubs or low trees. Q. ilicifolin.

11. Leares rommled or olotuse at the base, :3-.; lobed; lobes linear or lanceolate, often falcate. Q. trilobu.

16. Leares cuncate to truncate at the base, j-11 lobed; lobes triangular. O. pagodaefolia.

17. Leares usually pulvescent helow: winter buds tomentose; cup turbinate or hemisplierical; inner bark orange. Q. iclutina.

17. Leaves glalorous with the excepti n of tufts of hairs in the axils of the veins lelow: winter huds glabrous or

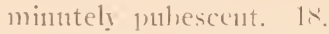

15. (un) of the acorn top-shaped or hemispleric. 1!).

Ix. Cup of the acoris shallow, satucer-shaped, wuch hroader than deep. 이.

19. Leaves clull, paler heneath; acor1i ovoid, ('u1) clepressedhemispheric. (). borealis.

1!!. Leaves shining m both sides, hlled to near the mi(l-rib: acorn ovoid: (11p) top-shapect. (). coccineu.

-11. Leaves clull: (cul) $1-1$ in. laruad: acorn wroid or elonsated. (). rubru.

2). Leaves shining decply pinnatificl: (1!) 1-1 in broad: acoril stublobose or ovid. O. pulustris.

\section{Chistumt oaks.}

1. Quercus prinus I.' Rock Chestmut Oak. A large tree with lorown hark, riclged close or slightly flaky. Leaves oblong, oblong-lanceolate, or obovate, coarsely crenate, glabrous alove, finely gray-tomentulose beneath, petioles slender: cup hemispheric, ${ }_{2}^{1}-11$ in. hroad, peduncles equalling or shorter tian the petioles: acorn ovoid, -2-:; times as high as the cup, seed edible but not very sweet. Self-prumes. WVod hard and strong; used in fencing and for railroad ties. Bark rich in tannin. In dry soil. Me. to Ont.. Ala., and Tenn.

.). Quercus michaùxii Nutt. Crm Oak. A large tree with llaky white loark. Leaves obovate or broadly oblong. crenately toothed, the teeth often mucromulate, t-8 in. long. cup depressech-hemispheric, short-peduncled, 1-11 in. broad: acorns ovoid, about 3 times as high as the cup, sweet and edible. Wood valuable like the White Oak. In moist soil. Del. to Ind., Mo., Ark., Fla., and Tex. 
:) Quercus muhlenbérgii Engchlı. (hestnut Oak. A tree with close gray hark. Leaves ollong, lanceolate, or whovate. coarsely toothed with acnte teeth, shining above. pale and gray-tomentulose heneath, t-li in. long; cup sessile of very short-peduncled, hemispheric: acorn ovoid about twice as high as the cup), sweet and cdible. Self-prunes abundantly. ITood strong and durable, much like White Oak Lsually in dry soil, commonly on line stone ridges. Vt. and ()nt. to Minn., Ala.. Veb., and Tex.

1. Quercus prinoides Willd. Serul) Chestnut Oak. I shrul) or small tree with gray bark. Leaves obovate, ccarsely toothed, bright green and shining ahove, gray-tomentulose beneath, narrowed at the base: enp sessile, hemispheric, thin: acorn ovoid, 2-3 times as long as the cup; seed sweet and edihle. Self-prunes. In dry sandy or rocky soil. Me. to Minn., Kan., Mla., and Tex.

5. Quercus bìcolor Willd. Swamp White Oak. I large tree with flaky gray bark. Leaves obovate, or ollonguborate, coarsely toothed or sometimes lobed nearly to the middle, dull and glabrous above, densely white-tomentulose leneatl, peduncles of the hemispheric cup ?-) times as long as the petioles; acorn ohlong-ovoid, seed rather sweet. Selfprunes. Wood similar in value to that of the White Oak. In moist or swampy soil. Quebec to Minn., Ga., and Ark.

V.

Quercus álba. L. White Oak.

1 large tree with a trumk up to $21 \mathrm{ft}$. in circumference and with light gray bark scaling off in thin plates. Leaves obovate, pinnatilid, lobes chlong. toother or entire: cup depressech-hemispleric, its hracts thick and warty, appressed; acorn ovoid-oblong, ; -1 times as high as the cup, sweet and edible. Intumn leaves red and russet. Self-prunes extensively. Wood light-colored. hard and tougly; valuable for many purposes: an ideal woul for railroad ties; used for poles, posts, and piling, for fuel and "acicl wood," for cooperage, furniture, interior linishing lumber, farm implenents, whares, ship luniding, and ear and wagon work. The nust laluable of the Inerican oaks. Hybridizes with (). macrocarpa, (). stellule and (). I'rimus. Ile. (1) Ont., Minn., Fla., Kanı, anul Tex. 
7. Quercus robur L. English Oak. A large strong tree with stout mure or less spreading branches forming a l,road round-topped head; self-prunes. Many forms are cultivated for ornament, including yellow-leaved and cut-leaved varieties, also forms with varied branches. Native of Europe.

\section{Quercus stellàta Wang. Post Oak. A shrub or} lisually a small tree with a long tap root and with rough gray lark and valuable wood. Leaves broadly obovate, deeply lyrate-pinnatifid, glossy and stellate-pubescent above, browntomentulose beneath, 4-8 in. long; cup hemispheric, nearly sessile; acorn ovoid, 2-3 times as long as the cup, very sweet. In dry soil. Miass. to Ohio, Mich., Iowa, Fla., and Tex.

9. Quercus lyràta Walt. Overcup Oak. A large tree with gray or reddish bark in thin plates. Leaves obovate, lyrate-pinnatifid or lobed to beyond the middle $6-8$ in. long. shining above, densely white-tomentulose beneath, cup de-

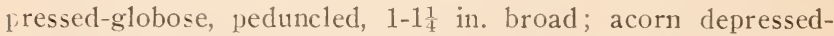
globose, nearly or quite immersed in the cup. IVood like in white cak. In swamps. N. J. to Ind., Mo., Fla., and Tex.

10. Quercus macrocàrpa $M_{\mathrm{x}}$. Bur Oak. A large tree with bark in narrow rough ridges, slightly flaky, and with a long tap root. Leaves obovate or oblong-obovate, irregularly lobed, pinnatifid, or coarsely crenate shining above, grayishwhite-tomentulose beneath, 4-8 in. long; cup short peduncled or sessile, hemispheric or subglobose, $\frac{1}{2}-1$ in. broad, the tips of the bracts forming a fringe around the acorn; acorn ovoid, 1-2 times as high as the cup. Self-prunes abundantly. A very valuable tree with hard and tough wood resembling the IVhite Oak. In rich soil or on river bluffs where it is sometimes small and shrubloy. N. S. to Man., Mass., Ga., Wyon., Kan., Tex.

\section{H'illow oaks.}

11. Quercus imbricària Mx. Shingle Oak. A large stout tree, the leaves dying off but remaining on the tree until about April 1. Leaves oblong or lanceolate, entire, persistently gray-tomentulose beneath, 3-7 in. long; cup hemispheric or turbinate, about $\frac{1}{2}$ in. broad; acorn subglobose, bitter. Wood poor; used for shingles and clapboards. Selfprunles twigs by means of basal joints. Q. leana Nutt. is a hybricl of this and $Q$. relutina. $Q$. tridentata Engelm. is a 
hybrid with $Q$. marylandica. Also hybridizes with $Q$. palustris. Pa. to Mich., Neb., Ga., and Ark.

12. Quercus phéllos L. Willow Oak. A tree with slightly roughened, reddish brown bark. Leaves narrowly-oblong or oblong-lanceolate, entire, very short petioled; cup saucer-shaped, nearly flat on the base; acorn subglobose, bitter. Wood poor. In moist woods. Hybridizes with $Q$. ilicifolia and probably with $Q$. rubra, producing the form known as Q. heterophylla. L. I. to Fla., Ky., Mo., and Tex.

\section{Black oaks.}

13. Quercus nigra L. Black Water Oak. A tree of rapid growth with gray bark, rough in ridges. Leaves spatulate or obovate, 1-3-lobed at the apex or some of them entire and rounded, short-petioled; cup saucer-shaped, rounded at the base, about $\frac{1}{2}$ in. wide; acorn globse-oroid, 2-3 timies as high as the cup. Wood heary, hard, and strong; used. for fuel. Usually along streams and swamps. Del. to Ky., Mo., Fla., and Tex.

14. Quercus marilándica Muench. Black-Jack (Oak). Usually a small shrubby tree; bark nearly black with very rough ridges. Leares obovate, 3-5 lobed toward the broad usually nearly truncate apex, cuneate below, the lobes short, stellate-pubescent above, brown-tomentose beneath when young, mature leaves glabrous above; cup deep, about $\frac{1}{2} \mathrm{in}$. broad; acorn ovoid, 2-3 times as high as the cup. In dry sterile soil. Hybridizes with $Q$. phellos and $Q$. ilicifolia. L. I. to Minn., Neb., Fla., and Tex.

\section{Red oaks.}

15. Quercus ilicifolia Wang. Bear Oak. A shrub o1 small tree, often forming thickets. Leares mostly obovate. 2-) in. long, short petioled, grayish-white tomentulose beneath, 3-7-lobed, lobes triangular-ovate, acute: cup saucer-

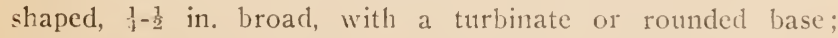
acorn globose-ovoid, longer than the cup. In sandy or rocky soil. Me. to Pa., Del., and in mountains to N. C. and Ky.

16. Quercus pagodaefòlia (E11.) Ashe. Swanp Spanish Oak A tree with spreading branches and dark gray, rongh hark. Leaves oval or oblong, cuneate to truncate at 
the base, s-1.2 in. long, deeply i-11-bobed, persistently whitetrmentulose leneath, lobes narrowly triangular, sprearling or somewhat ascending, usually entire: (cup) sessile, shallow. acorn globose, about $\stackrel{1}{2}$ enclosed in the cup. In wet or moist soil. Mass. to lila., M11.. Mr.., and . trk.

17. Quercus tríloba Mx. Spanish ()ak. I tree growing in dry soil. Leaves glabrous above, gray-tomentulose leneath, deeply pinnatifiel into :3-7 linear or lanceolate lobes: cup sancer-shaped with a turbinate base, about $\stackrel{1}{2}$ in. broad: acorn suloglobosc and depressed, about twice as high as the cup. Wood very hard and strong; userl for comprage. An important tanhark oak. N. J. to Fla., (Ohio, Mo, and Tex.

18. Quercus velùtina Lam. Quercitron Oak. A large tree of rapid growth with very dark brown bark, roush in ridges, and bright orange inner bark. Leaves firm, sometimes lohed to leyond the middle, brown-pubescent or sometimes stellate-pubescent when ycung. glabrous and shining when mature, the lobes broad, oblong or triangular-lanceolate: cup hemispheric or top-shaped, commonly narrowed into a short stalk: acorn ovoid, as long or longer than the cup. The inner bark (quercitrcn) yields a valuable dye; rich also in tannin. IVood hard, heary, and strong but not tough. Sparingly self-prunes small twigs hy means of basal joints. Me. to Minn., Fla., Neb. and Tex.

19. Quercus boreàlis Mx. f. Gray Oak. A large tree with leaves like those of $Q$. rubra and acorns like those of Q. coccinct. Leaves $i-13$ lobed to the middle or somewhat licyond; cup turbinate, peduncled: acurn ovoid, 1-2. times as long as the cup. (unebee to Ont.. X. Y... and Penn.

201: Quercus coccínea IVang. Scarlet Oak. I tree "it'i pale redclish or gray inner bark. Leaves deeply pin1atifid, glabrous, bright green ahove, paler beneath, $t-x$ in. long; cup hemispheric or top shaped, acom ovoid, abont twice as long as the cup. Autumn leaves red. In dry soil. We to Minn.. Mo. and $\mathrm{N}$. Car.

XX Quercus rùbra L. Red Oak. I large tree with rark gray hark, somewhat roughened. Leaves (val or semewhat wovate, $1-x$ in. long, dull green above, paler bencath. lohes triangular-ianceolate, tapering from a broat base to an acuminate ajex: culp saucer-shaped, its hase flat or slightly 
convex, $\frac{1}{2}-1$ in. broad; acorn ovoid, 2-1 times as long as the (up). Intumn leaves purplish red. Wood very coarse-grained. redisis in color. porous, and not very durable: used in carpentry, cooperage, and for clapboards. The most rapid grower of all the oaks. In important tree for tan-bark. Sprouts readily from stumps. X. S. to Ont.. Minn., Fla., Kanl, and Tex.

2.). Quercus palústris DuRoi. Pin Oak. A mediumsized tree with brown bark, rough when old, the lower branches deflexed. Leaves broadly oblong or olorate, deeply pinnatilit, brighter green and shining above, dhiller beneath, b-; in. long, the loles ollong, lanceolate or triangularlanceolate: divergent: cup sancer-shaped, 1-1 in. broad, base flat: acorn stibglobose or ovoid, 2-? times as long as the cup. 17 ood coarse-graincel, reddish, and not durable. In moist grouncl. Mass. (Ohio and ITis.. Ta., and Ark.

\section{Belulaceac. Birch diamily.}

ㄱ. Carpinus (Tourn.) 1. Blue-beech.

Small tree's with alternate, ’-ranked, simple, straightveinerl, efuilateral, serrate leaves: with peculiar Huted or projecting ridges on the trunks and larger branches: and " ith dark, smooth bark.

Flowers in aments: monecions: nuts small in the largebracted fruiting ament; bracts leaf-like.

1. Carpinus caroliniàna Walt. Blue-beeclı. A small tree with slender terete gray twigs. Wood light brown, very compact, strong, and heary, not durable in the ground: nsed for turiery, toul landles, etc. The charcoal is used for making powder. In moist soil and along streams. I. S. tc: Minn., Fla., Kan., and Tex.

\section{ix. Óstrya (Nicheli) Scop. Hop-hornbeant.}

Snall trees with alternate, 2-ranked, simple, straightveined, equilateral, serrate leaves: with glandular pulescent young twigs and fine-furrowed scaly bark.

Flowers in aments; monecions; ntits small, in a-hop like fruiting ament.

1. Ostrya virginiàna (Mill.) WVilld. Hop-hornbeam. A small tree with scaly hark. IVood white, compact, very 
hard and strong. In dry or muist soil. Cape Breton I. to Man., Fla., Neb., Kan., and Tex.

\section{Bétula (Tourn.) L. Birch.}

Trees or shrubs with simple, serrate, 2-ranked leaves; with small samara-like nuts in a cone-like ament, and frequently with papery or leathery bark.

Usually aromatic, monecious, styles 2, ovulary bilocular.

1. Leaves usually cordate or rounded at the base, sharply serrate, only slightly doubly serrate; bark brown or yellowish, close or separating into layers; bark of twigs with wintergreen flavor; fruiting aments sessile or nearly so. 2.

1. Leaves acute, obtuse, or truncate at the base, rarely cordate, prominently doubly serrate or serrate-dentate; bark chalky white or greenish brown; bark of twigs not with the flavor of wintergreen, usually, bitter; fruiting aments peduncled. 3 .

-). Bark not separating in layers, becoming furrowed; leaves shining above; fruiting bracts glabrous or pubescent. less than $\frac{1}{4}$ in. long, lobed at the apex. B. lenta.

2. Bark separating in papery layers when old, somewhat silvery; leaves dull above; fruiting bracts ciliate, more than $f$ in. long, lobed to about the middle. $B$ lutea.

3. Bark greenish or reddish brown, peeling in papery layers especially above; leaves rhombic, acute at both ends; young leares, twigs, and aments tomentose; fruiting aments oblong, erect. B. nigra.

3. Bark of trunk and larger branches chalky white, usually peeling off in thin layers: fruiting aments cylindrical, pendant or spreading. 4 .

4. Leares deltoid, very long acuminate at the apex; bark not readily separable into thin layers; twigs with numerous resinous glands. B. populifolia.

4. Leaves acute or acuminate, usually ovate, in some cultivated forms of various shapes; bark peeling off in thin layers. j.

5. Leaves ovate or suboricular; native, occasionally cultivated. B. papyrifera. 
j. Leaves various, commonly triangular or rhombic-ovate, on slender petioles; twigs often pendulous or weeping; much cultivated, from Europe and Asia. B. alba.

1. Betula lénta 1. Sweet Birch. A large tree with dark brown, close, smooth bark, becoming furrowed and not separating in layers. IVood hard, fine-grained, of a reddish tint: used for cabinet-work. N. Eng. to Ont., Fla., and Tenn.

2. Betula lùtea Mx. f. Yellow Birch. A large tree with yellowish or gray bark, separating in thin layers or close. Autumn leaves pure yellow. Wood hard and closegrained: used in making furniture, wheel-hulls, pill-boxes, etc. Newf, to Man., N. Car., Ga., and Tenn.

\$. Betula nigra L. River Birch. A slender tree with reddish or greenish-brown bark peeling off in very thin layers. Branches long and slender, arched and heavily drooping. Wood rather light, hard, strong and close grained; used for furniture and turnery. "Birch brooms" are made from the twigs. Along streams. Mass. and N. H. to Iowa, Minn.. Kan., Fla., and Tex.

4. Betula papyrifera Marsh. Paper Birch. A large tree with chalky white bark separating in thin layers. The bark is very water-proof and is used for making canses by Indians and trappers. Wood rather heavy, hard, and very close-grained: decays rapidly when exposed; used for making spools, pegs, shoe-lasts, wooden shoes, wagon hubs, oxyokes, wood-carving, wood pulp, and in wood turnery. Newf. to Alaska, Penn.. Mich., Neb., and Wash.

5. Betula álba L. European White Birch. A tree with chalky-white bark, much cultivated for ornament, especially. the "weeping" and cut-leaved varieties.

(i. Betula populifòlia Marsh. American White Birch. A slender, short-lived tree with smooth white bark, tardily separating in thin sheets. Autumn leaves pure yellow. IVood soft, white, not durable: used for making spools, shoe-pers, etc. Leaves tremulous like those of the aspens. In moist or dry soil. N. S. to Ont., Penn., and Del.

\section{0. Álnus (Tourn.) Hill. Alder.}

Trees or shrubs with 3 -angled pith, alternate straightveined, simple leaves and stalked winter buds. 
Monecious: nuts small, compressed, in wooly cone-like aments which are persistent throughout the year.

1. Leaves obovate, hroadly oval or suboricular, dull: catkins expanding long before the leaves. -).

1. Leaves oblong, shining alove, catkins expanding in atttumn1. I. Miaritima.

2. Leares lincly tomentose or glancons leencath. 1. incana.

2. Leaves green, glabrous or sparingly pubescent beneath. $: 3$.

$\therefore$ Leaves hinely serrulate, foliage not glutinous. A. rugosa.

:3. Leaves dentate-serrate: twigs glutinous. 4. alnus.

1. Alnus incàna (L.) IVilld. Hoary Aleler. I shruh) or small tree with the young shoots puhescent. $1 V^{r}$ owd soft. light brown. In wet soil. Newf. to Sask., X. Y.. Penn., (O)io and Nei). Also in Europe and Isia.

2. Alnus rugòsa (DuRoi) Spreng. Smouth Alder. I slirub or small tree with smooth bark, the young shoots somewhat pulsescent. Woud soft, light brown. In wet soil or on hillsides. Me. to Ohio, Minn., Fla., and Tex."

3. Alnus álnus (I..) Britt. European Alder. A tree of rapid growth, developing readily in ordinary dry soil Usually in wet places. Wood soft, brown. Native of Europe, \ewi., andi $\$. J. to Ill.

4. Alnus maritima (Marsh.) Muhl. Seaside Alder. I sinall tree, glabrous or nearly so. Nood soft, light brown. In wet soil. Del. and MId.; also in Okla.

Juglandaceae. IValnut Family.

61. Hicòria Raf. Hickory.

Large trees with alternate serrate ordd-pinnate leaves, terminal buds. i-angled solid pith, and numerous bundle scars scattered or in :3 areas.

Monecious; axillary buds superposed; staminate flower: in slender aments; fruit a 11 t in a husk.

1. Terminal bud-scales valvate, $4-6$ : leaflets $7-1.5$, lanceolate or oblong-lanceolate, more or less falcate. 2.

1. Terminal hud-scales imbricate, more than i: leaflets :3-?, not falcate, thic uppermost larger and generally olovate. 1. 


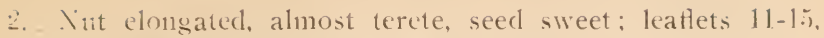
inequilateral, acuminate. /1. pecon.

2. Nit somewhat compressed or angled, ustrally as broad as long; seed intensely bitter; lateral leaflets falcate. 3. 3. Leaflets $7-11$; nut smooth; husk thin, splitting to below the midclle. II. cordiformis.

:). Leaflets (1-1:); nut angled, lutusk thin, splitting to the base. H. alluatica.

4. Terminal bud large, $\frac{1}{2}-1$ in. long: husk splitting freely to the hase, nut angled, seed sweet; middle lobe of the staninate calyx narrow, often at least twice as long as the lateral ones. 5.

1. Terminal hud small, $1-\frac{1}{2}$ in. long: husk thin, not splitting freely to the luasc. nut slightly or not angled; lobes of the staminate calyx mostly nearly equal. ?.

$\therefore$ liark shaggy, separating in long plates: husk very thick, splitting to the base: otter bud-scales persisting through the winter. $(i$.

5. Bark close, rough: leaflets $7-9$, stellate pubescent: outer bucl scales falling away in autumn: lutsk not separating quite to the hase: twigs and petioles tomentose. H. alba.

i. Leaflets :;-r, rarely 7 , nut rounded at the base; $\frac{1}{2}-1$ in. long. $T$.

1i. Leallets $7-!$ : nut usually pointed at both ends, $1-1 \frac{1}{1}$ in. long. II. laciniosa.

7. Leaflets oblong-lanceolate to obovate: twigs puberulent. II. öatat.

7. Leaflets narrowly lanceolate: twigs glancous. H. carolinae-septentrionalis.

$\therefore$ Liruif nearly globular: nut thin-shelled; hark of old trees scparating in strips: leaflets $j-\bar{\tau}$. H. microcurpa.

$\therefore$ Fruit obovoid: nut thick-shelled: bark close. !.

?. Leaves glabrous or nearly so: leaflets i-T, rarely :3 or !?. H. ylabra.

!) [eaves with silvery peltate glands: leaflets i-!?. $H$. rillosa.

1. Hicoria pecán (Marsh.) Britt. Pecan (Ilickory). I large tree of rapid growth with rough hark and a long tap root. Leaflets 11-15, ololong-lanceolate, short-stalked, in- 
equilateral, acuminate; fruit oblong-cylindric; husk thin, 4valved: nut smooth, oblong, thin-shelled, pointed, seed delicious and important commercially; wood hard, brittle, light brow11. Nlong streams and in moist soil. Ind. to Iowa and Kan., south to Ala. and Tex.

-) Hicoria cordifórmis (Wang.) Britt. Bitternut (Hickory). A slender tree with close rough bark. Leaflets $7-11$, sessile, long-acuminate, the lateral ones falcate; fruit subglcbose, narrowly ti-ridged; husk thin tardily and irregularly t-ralved; nut short-pointed, thin-shelled. IVood heavy, strong, and tough. In moist woods and swamps. Quebec to Minn., Fla., and Tex.

3. Hicoria aquática (Mx. f.) Britt. Water Hickory. I tree with close bark, living in swamps. Leaflets 9-13, lanceolate, or the terminal one oblong, long acuminate at the apex. narrowed at the base, the lateral ones falcate; fruit ( hons, ridged, pointed; luss thin, tardily splitting; nut oblong, thin-shelled, angular. Wood $\delta$ f poorer quality than that of other hickories. Va. to Fla., Ill., Ark., and Tex.

4. Hicoria microcàrpa (Nutt.) Britt. Small-fruited Hickory. A tree having the older bark separating in narrow plates. Leaflets $5-\bar{\tau}$, oblong, or ovate-lanceolate, acuminate at the apex: fruit globose or globose-oblong; husk thin, tardily and incompletely splitting to the base; nut subglobose, slightly compressed, thin-shelled, pointed; seed sweet. WVod hard, strong and tough. In rich soil. Mass, to Ohio and Mich., Va., Ga., Ill., and Mo.

¡. Hicoria glàbra (Mill.) Britt. Pignut (Hickory). A tree with close rough bark. Leaflets $3-\bar{\tau}$, rarely 9, oblong, oblons-lanceolate or the upper obovate, sessile, acuminate at the apex, usually narrowed at the base; fruit obovoid or obovoid-tblong; hush thin, the valves very tardily dehiscent; nut brown, angled, pointed, very thick-shelled; seed bitter and astringent, not edible. Wood hard, strong, tough, and rather dark brown. In dry or moist soil. Me. to Ont., Minn., Kan., Tex., and Fla.

(i. Hicoria villòsa (Sarg.) Aslıe. Scurfy Hickory. A small or medium-sized tree with deeply furrowed, dark gray bark. Leaftets ,5-!), thickly covered beneath with silvery peltate glands, mixed with resinous globules, generally pubescent; fruit ohoroid, the husk partly splitting; nut brown, thick- 
shelled, angled; seed small, sweet. Wood hard and dark brown. Del. to Fla. and Mo.

7. Hicoria álba (L.) Britt. Mockernut (Hickory). A large tree with close rough bark. Leaflets 7-9, oblonglanceolate or the upper oblanceolate or obovate, long-acuminate; fruit globose or oblong-globose; husk thick; nut grayishwhite, angled, pointed at the summit, little compressed, thickshelled; kernel small but sweet and edible. Wood much like in H. ovata, very hard and tough, dark brown. In rich soil. Nass. to Ont., Neb., Fla., and Tex.

8. Hicoria laciniòsa (Mx. f.) Sarg. Shellbark (Hickory). A large tree with the bark separating in long narrow plates and with a long tap root. Leaflets $7-9$, rarely $i$, acute or acuminate, sometimes \& in. long: fruit oblong; husk thick, soon splitting to the base; nut oblong, somewhat compressed. thick-shelled, pointed at both ends, yellowish-white; seed sweet and edible. Wood like in H. ovata, strong and tough. In rich soil. N. Y. and Ohio to Iowa, Kan., Okla., and Tenn.

9. Hicoria carolinae-septentrionàlis Ashe. Southern Shagbark (Hickory). I tree with gray bark hanging in loose strips. Leaflets :3-5, glabrous, ciliate; fruit subglobose: husk soon falling into four pieces; nut white or brownish, mucl compressed, angled, cordate or subcordate at the top, thin-shelled. In sandy or rocky soil. Del. to Ga., and Tenn.

4tH. Hicoria ovàta (Mill.) Britt. Shagbark (Hickory). A large tree with shaggy bark in narrow plates. Leaflets 5 , sonctimes $\bar{T}$, oblong, oblong-lanceolate, or the upper obovate. acuminate at the apex, narrowed to the sessile base; fruit suloglolose; husk thick, soon splitting; nut white, somewhat compressed, pointed, slightly angled, thin-shelled. Seed finely fiavored, most "hickory nuts" of the markets being from this species. Wood very heary, hard, tough, and elastic; used for agricultural implements, carriages, wagon stock, axehandles, cooperage, sucker rods, wheel spokes, etc. Also a fine fuel wood. Not durable in the ground. In rich soil. Quelec to Minn., Fla., Kan., and Tex.

\section{(i.). Jùglans $\mathrm{I}$. Walıut}

Large trees with laternate odk-pinnately compound leaves and diaphragmed pith. 
Monecious: axillary hucls smperposed; staminate flowers in slender catkins: frinit a nut in a tleshy husk; seed edible.

1. Leaflets alm st cutire: nut rather smooth and thinshelled; twigs glabrous. I. regia.

1. Leaflets serrate; mit rongh, thick-shelled. 2..

ə. Petioles smoothish or puberulent; axil of leaf without a hairy cushion below the londs; hark brown or black, rongh; fruit globose, not riscid. I. ni.gra.

․ Petioles pulescent, sticky or gummy when young; axil if the leaf with a hairy cushion below the buds; bark gray, the ridges smooth on the surface; fruit oblong, I iscirl. I. cincrea.

1. Juylans rigia 1. English Wahnut. A round-headed tree with the leaflets almost entire and nearly glabrous. Husk of the nut frialsle. (inltivated for the sweet nuts; from Asia.

2. Juglans nigra $\mathrm{I}$. Black Walnut. A large tree with a trunk up to $-4 \mathrm{ft}$. in circumference and with rough brownisl llack loark and a long tap reot. Wood heavy, hard, strong, of coarse texture: heart-wood dark brown, of great value; used for calinet-work, interior finish, gun-stocks, turnery, and as veneer. Coimmon on Hood plains of streams. Mass. to Ont. and Minn., sonth to Kan.. Tex. and Fla.

:). Juglans cinèrea L. Putternut. A large tree with gray bark the outer surface of the ridges smooth. Heartwood lighter colored and softer than in J. nigra; used for ornamental cabinet-work, interior finish, and cooperage. In rich or rocky woods. X. B. to X. Dak., Kan., 1)el., Ga., Ark., and Miss.

\section{Mricaceac. Bayherry Family.}

\section{(i:). Myrica I. Bayberry.}

Shrubs or small trees with alternate simple peltate-scaly or resin-dotted leaves: with cylindrical pith, :) hundle scars and glandinlar-dotted twigs.

Mostly diecions; flowers in catkins: drupe globose or ovoid: its exocarp waxy.

1. Myrica cerífera L. Wax-myrtle. A slender diecions tree with gray, nearly smooth bark. Leaves persistent through the winter. Wood light, brown in color. In sandy swamps or wet woods. Penn. and N. J. to Md., Fla., and Tex. north to Ark. 


\section{()rder, SALICALES.}

Salicaceac. Willow Family.

\section{6it. Pópulus L. Poplar.}

Large trees with alternate simple leaves, not 2 -ranked and not entire but with gland-tipped teeth; with 5 -angled pith, 3 bundle scars, and terminal, more or less resinous buds with several bud scales.

Diecions; flowers in aments; fruit a capsule: seeds with long cottony hairs; leaves mostly with 2 or more glands at or near the base of the blade; twigs prominently self-pruned hy means of cleavage planes in hasal joints.

1. Leaves and twigs persistently and densely white tomentose below, usually lohed: self-pruning scars very prominent on the small twigs. P. alba.

1. Leares and twigs glabrous or nearly so when old, not lobed. 2.

2. Petioles terete or chammeled, not much flattened laterall;: leaves crenate. 3.

-2. Petioles strongly flattened laterally. 4.

;. Leaves densely tomentose when young often with? small lohes at the base; capsule slender-pedicelled. $P$. h.lerophylla.

:) Leaves not tomentose hut usually somewhat pubescent: capsule short-pedicelled. P. balsamifera.

4. Leaves broadly deltoid, abruptly acuminate: terminal winter buds usually angular. ;.

4. Leaves hroadly ovate or sulurbicular; terminal winter buds rounded or unly slightly angular. 7 .

.) Trees of tall, narrow growth with strongly erect hanches. giving a spire-lilie appearance, young twigs glabrous: leaves usually wider than long, more or less acute at the hase. I'. italica.

j. Trees with spreading branches. if.

6. Young leaves pubescent: capsules nearly sessile. P. niqra.

6. Young leaves not pubescont, shining: capsules slenderpedicelled. !'. delloides.

7. I.eaves coarsely sinuate-dentate, densely white-tomentose when young, slabrous when mature. I'. yrandidenlata. 
7. Leaves crenulate-dentate, glabrous except the ciliate margins. P. tremuloides.

1. Populus álba L. White Poplar. A large tree with smooth, light, greenish-gray bark often with black diamondshaped scars; sprouting freely from the roots and hence not desirable for yards. Young foliage densely white-tomentose, the leares becoming glabrate and dark green above, broadly ovate or nearly orbicular in outline, 3-5 lobed, or irregularly dentate, -4 in. long. Wood soft and nearly white. Native of Europe and Asia. N. B. to Ont., Va., and Ohio.

2. Populus heterophýlla L. Swamp Poplar. An irregularly branching tree with rough bark. Leaves longpetioled, broadly ovate, crenulate-denticulate, $5-6$ in. long. Wood soft, compact, weak, brown in color. In swamps. Conn. to Ga., west to La. and northward to Mo., Ind. and Ohio.

3. Populus balsamífera L. Balsam Poplar. A large tree with nearly smooth gray bark. Leaves broadly ovate, dark green and shining abcve, pale beneath, rounded or acute at the base, crenulate, 3-5 in. long. Wood very light and soft, weak, brown. In moist or dry soil, commonly along streams and lakes. The subspecies P. balsamifera cándicans (Ait.) Gr. Balm-of-Gilead, has the leaves broadly ovate, truncate or cordate at the base, and the petioles and nerves ustially puberulent. Mostly escaped from cultivation. Newf. to Alaska, south to Va., Ohio, S. Dak., and Ore. -1. Populus deltoides Marsh. Cottonwood. A large tree of very rapid growth, with rough, deeply furrowed, brown hark when old. Bark of young trees grayish-green and rather smooth. The giant of the poplars. Petiole much flattened laterally causing the leaves to rustle in the wind. Leaves glabrous, broadly deltoid-ovate, abruptly acuminate at the apex, crenulate, truncate at the base, 1-7 in. long. Wood light and soft and very durable if kept in the dry; used for building lumber, light boxes, paper pulp, sugar and flour barrels, cracker boxes, crates and wooden warè; also a good fuel wood. A most useful and crnamental tree of very rapid growth if planted in ravines and low places. In cities only staminate trees should be planted. In favorahle soil often attaining a trunk diamcter of $3{ }^{1} \mathrm{ft}$. in 10 years. In moist soil. 
especially on the bankis and flood plains of creeks and rivers. Quebec to Man., south to Fla., Kan., and N. Mex.

j. Populus nigra L. Black Poplar. A large tree witl: terete twigs. Nature leaves firm, hroadly deltoid, abruptly acuminate at the apex, broadly cuneate or obtuse at the base, crenate, 2-4 in. long. Naturalized from Europe. N. Y. and southward along the Delaware R.

6. Populus itálica Moench. Lombardy Poplar. A spire-like tree of rapid growth. Commonly planted for ornament.

7. Populus grandidentàta $M x$. Largetooth Aspen. A tree with smoth, greenish-gray bark. Leaves tomentose when young, glabrous when mature, short-acuminate, obtuse or truncate at the base, $2-4$ in. long. Wood soft and white: used for paper pulp. In rich moist soil. N. S. to Ont. and Minn., south to N. J. and Ohio, and in the Alleghanies to Tenn.

8. Populus tremuloides $\mathrm{Mx}$. American Aspen. A slender tree with light green, smosth bark. Leaves usually short-acuminate at the apex, finely crentilate, truncate, rounded or subcordate at the base, 1-3 in. broad. Petioles very slender, causing the leaves to quiver and rustle in the slightest breeze. Wood white and soft; used for making coarse paper. In moist or dry soil. Newf. to Alaska, south to N. J., Ohio, Ky., and Neb.: in the Rocky Mts. to Mexico and to Lower Cal.

\section{6.). Sàlix (Tourn.) I.. Willow.}

Shrubs or trees with alternate simple serrate pinnately reined leaves and axillary buds with a single outer scale.

Diecious; flowers in aments; fruit a capsule, the seeds with long cottony hairs; leaves sometimes with glands on the petiole or at the base of the blade and with gland-tipped teeth. Twigs self-pruned by means of basal brittle zones. The charcoal from the larger specics used for making gunpowder.

1. Twigs decidedly pendulous or "weeping", green or yellowish-green; leaves linear-lanceolate, acuminate, serrulate, smooth, rather pale bencath, petioles glandular above; capsule glabrous, pedicel very short, stigma sessile, S. babylonica. 
1. Twigs not pendulous nor weeping, hut some may be drouping. 2.

-. Leaves tapering to the short petioled or nearly sessile hase, linear-lanceolate, remotely denticulate. coarsely silky when young. usually glabrate in age; shrubs or small trees with a narrow, slender crown: capsule glahrous or silky. Stamen -. S. interior.

$\because$ Petioles present and rather prominent and slender except in some individuals. :?.

3. Leaves silky, tomentose, or hairy below when mature: stamens :). !.

$\therefore$ L.eares glabrous below, or nearly so, when mature, sometimes fincly pubescent when young. 5.

1. Leaves $1 \mathrm{ng}$ linear-lanceolate, sparingly repand-crenulate, or entire, white or silvery silky beneath, without glands on the petiole, acuminate: twigs terete, green: capstule nearly sessile, silky or tomentose, style long. s. aiminalis.

4. Leaves lanceolate, narrowed at the hase, serrulate, silky pubescent and glancous beneath, usually with glands on the petiole at the base of the blade: capsule glabrons. pedicel very short, stigma sessile. S. alba.

4. Leaves ovate-lanceolate, slender-pointed, firm, pubescent or white-tomentose beneath, sharply serrate or entire: lracts yellow, linear-oblong or lanceolate: capsule silky or tomentose, pedicel filiform. S. bebbiana.

$\therefore$ Petioles nsually without glands, or if with glands then the leaves of the sate type and short pointed: stamens -). li.

$\therefore$ Petioles ustrally with glands on the top or at the hase of the hlade: stamens :3-12., in one species :- capsule slabrous. $\therefore$

i. Length of leaf-blade less than 3 times its breadth: mature leaves thin and dull, elliptic, ovate-oval, or oborate, acute or obtuse at the apex; stamens -). $S$. pyrifolia.

ii. Length of leaf-blade 3 times its breadth or mcre. 7 .

7. leaves oblanceolate or spatulate, acute, serrulate, somewhat glaucous beneath: twigs purplish, flexible: filaments of stamens united; capsule silky or tomentose. sessile; stigma sessile. S. purpurea. 
7. Leaves lanceolate or ublanceolate, acmminate, linely serrate with minute gland-tipped teeth, pale and glancous beneath; twigs of the season pubescent or puberulent; capsule glabrous. S. cordata.

¡. Leaves obovate, oblong or oblanceolate, rather thin, acute at both ends; irregularly or indistinctly toothed glaucous and nearly white beneath; bracts fuscous, ohovate or cuneate, long-hairy: capsule silky or tomontuse, stalked. S. discolor.

$\therefore$ Petioles short: leaves narrowly lanceolate, usually falcate, narrowed at the base, glabrous or slightly pubescent, green on both sides or slightly paler beneath. S. nigra.

$\therefore$ Petioles rather prominent and slender exept. in some individuals; leaves lanceolate or broader. !).

9. Leares dark-green above, glaucous or whitish heneath not coriaceous. 10.

!) Leaves yellow-green and glossy on both sides, thick, normally ovate, very long acuminate with a slender tip: catkins thick and dense, stamens mostly :3, Hower bracts lentate; capsule large, short-pedicelled: twigs brown, polished. S. licida.

10. Leares orate-lanceolate, broadest below the middle, acuminate, petioles often red; stamens .7-12: capsule narrow-conic, pedicel slender, :3-; times as long as the gland: bark rough, brown. S. amyludaloides.

11. Leaves lanceolate, long-acute; stamens -), capsules very narrow-conic, pedicel short, about twice as long as the gland: bark gray. 5. fragilis.

11. Leaves lanceolate or oblong-lanceolate, rounded, sul)cordate, or narrowed at the hase, $8-8$ in. long: very white and somewhat pulescent beneath: capsule conic, pedicel slender, :3-; times as long as the gland: hark dark reddish-brown with small scales. S. a'ardi.

1. Salix amygdaloides And. Peachleaf Willow. A tree with rough, brown, scaly hark. Leaves pubescent when young, glabrous when old, dark green ahove, pale and slightly glaucous beneath, narrowed at the base, :3-, in. long, $\frac{1}{2}-\frac{3}{1}$ in. wide; capsule narrowly oroid, acute, glabrous, finally about 
as long as the filifurm pedicel. Mong streams, lakes and ponds. Quebec to Br. Col., X. Y., Ohio, Mo., and N. Mex.

$\stackrel{2}{2}$ Salix nigra Marsh. Black. Willow. A mediumsized tree with rough, Haky, dark brown bark. Leaves narrowed at the base, serrulate, 2-; in. long, $\frac{1}{6-1}$ in. wide, or wider: capsule ovoid, acute, about as long as its pedicel. Along streams and lakes. The subspecies S. nigra falcata (Pursh.) Torr has narrower more falcate leaves. Hybriclizes with S. alba. N. B. to Ont., Fla., Cal. and Kan.

3. Salix wàrdi Pelol. Ward Willow. A tree with spreading or drooping branches and dark reddish-brown hark. Leaves lanceolate or olnong-lanceolate, rounded, subcordate, or narrowed at the base, -7 in. long, $\frac{1}{2}-1 \frac{1}{2}$ in. wide. scmewhat pubescent heneath: capsule conic. Wood dark brown. Along streams and lakes. Md. to Kan., south to Fla.. and Ark.

4. Salix lùcida Muhl. Shining Willow. A tall shrul) or small tree with smooth or slightly scaly bark, the twigs yellowish brown and shining. Leaves lanceolate, ovatelanceolate, or ovate, mostly long-acuminate, narrowed or rounded at the hase, sharply serrulate, green and glossy on both sides or with a few scattered hairs when young $3-5$ in long. $3-21$ in. wide; capsule narrowly ovoid, acute, glabrous, much longer than its pedicel. A very beautiful willow in swamps and along streams and lakes. Newf. to N. W. Ter.. N. J., Ohio, Ky., and Neh.

.) Salix frágilis L. Crack Willow. A tall slender tree with roughish, gray hark and green branches. Leaves lanceolate, long-acuminate, narrewed at the base, sharply serrulated, glabrous on hoth sides, rather dark green above, paler leneath, : - -fi in. long, $\frac{1}{2}-1$ in. Wide; capsule long-conic. Twigs nsed for hasket work. Native of Europe. Hybridizes with S. alba. Mass. to X. J., Ky. and Ohio.

6. Salix intèrior Row. Sandbar Willow. A shrub or small slender tree nsually forming thickets. Flowers can be found frir a long time. l.eaves lincar-lanceolate, acuminate, remotely denticulate with somewhat spreading teeth, shortpetioled; 2.1-t in. long; capsule ovoid-conic, linely silky when young, glabrate in age. Mlong streams and ponds and in ravines, sometimes on high ground. Quehec to N. W. Ter., south to $\mathrm{Va}$. and Texas. 
¡. Salix álba L. White Willow. A large tree witl rough gray bark. Leaves lancelate, narrowed at the base, serrulate, silky-pubescent on both sides when young, less so and pale and glaucous beneath when mature, -2-5 in. Iong, 1-? in. wide; capsule ovoicl, acute. In moist soil. Native of Europe. The sulspecies S. alba vitellina (L.) Koch., has the nature leaves glabrous and the twigs yellowish-green. N. S. and Ont. to N. C. and Iowa.

\section{Salix babylónica L. Weeping Willow. A large} graceful tree with weeping branches, often planted in yards and cemeteries. Leaves linear-lanceolate, serrulate, narrowed at the base, glabrous when mature, green above, paler beneath, -6 6 in. long, $\frac{1}{4}-\frac{1}{2}$ in. wide; capsule ovoid-conic. Native of Asia. Conn. to Va. and Mich.

\section{Salix pyrifòlia And. Balsam Willow. Usually a} shrub but sometimes arborescent with a slender erect stem. Leaves elliptic, ovate-oval, or obovate, thin, glabrous, acute at the apex, rounded or subcordate at the base, glaucous beneath, $2-3$ in. long, $3-1 \frac{1}{2}$ in. wide, slightly crenulate-serrulate: capsule very narrow, acute. In swamps. Newf. to P. C. south to Me., Mich., and Minn.

10. Calix cordàta Muhl. Heartleaf Willow. A tree or shrub with small, appressed scales on the thin bark. Leaves lanceolate, or oblanceolate, acuminate, finely serrate with minute gland-tipped teeth, rounded or narrowed at the base, glabrous or nearly so when mature, pale beneath, $2 \frac{1}{2}-\mathrm{y}$ in. long, 2-1 in. wide; capsule ovoid. Wood lark brown. On river banks and in moist places. N. P. to B. C., Va., Mo., Col., and Cal.

\section{Salix viminàlis L. Osier Willow. A small slen-} der tree or shrub with green twigs. Leaves long linearlanceolate, sparingly, repand-crenulate or entire, revolutemargined, short-petioled, glabrous above, silvery-silky beneath. 3-6 in. long; capsule narrowly oroid-conic, acute. Cultivated for wicker-ware. Native of Enrope and Isia. Newf. to Penn.

12. Salix bebbiàna Sarg. licbl) Willow.. A slurub or small tree. Leaves elliptic, oblong, or olslong-lanceolate, sparingly serrate or entire, dull green and puberulent above, pale and tomentose beneath, nearly glabrous when very old; capstile very narrowly long-conic, twice as long as the filiform 
pedicel. In dry soil along streams. \ewf. to Maska, ․ J.. ()ino, Neh., and Utais.

1:: Salix díscolor Muhl. Pussy Willow. I shrub or low tree in swamps or moist hill-sides. Leaves obovate, oblong or oblanceolate, usually glabrous, glaucous and nearly white beneath, irregularly serrulate or nearly entire. slenderpetioled, 1. $12-4 \mathrm{in}$. long; capsule narrowly crnic, tapering to a slender heak. I. S. to Sask., I)el. and Mo.

14. Salix purpùrea L. Purple Willow. I slender shruh or small tree with smooth and very bitter bark, the laranches often trailing. Leaves oblanceolate or spatulate. acute, serrulate, narrowed at the hase, short-petioled, glahrous alove, paler and somewhat glaucous beneath, 11-20 in. 1ng: capsule ovoid-conic, oltuse, tomeitose. (intivated for wickerware. Vative of Europe. Escaped from ()nt. ąnd Ohio eastward.

Suluclass, Heteromik.IF.

Order, ERICALF:

Ericaccai. Heath Family.

(j6. Rhododéndron L. Rhododendrum.

Shrubs or small trees with simple, alternate, entire, pinnately reined, coriaceous, evergreen leaves and very scaly winter louds.

Flowers showy, hisporangiate, pentamerous, sympetalous: fruit usually a woody capsule with numerous seerls.

1. Rhododendron máximum 1.. Great Rlododendron. I tall shrub or small tree with beantiful flowers and striking evergreen leaves. Leaves poisonous to stock and the nectar saicl to produce poisonous honcy. On rocky hillsides and al:mg streams. ()ecasionally cultivated. I. S. to ()nt., Ohio. (ia. and Mla.

\section{(iii. Kálmia 1. Kálmia}

Shruls or small trees with simple, alternate, entire, pinnately veined, coriaceous erergreen leaves, and with naked winter buds.

Flowers lisporangiate, pentamerons, sympetalous; stamens 111. the anthers at hirst in 11 pouches, sympetalous: fruit a capsule with small seeds. 
1. Kalmia latifòlia 1.. Mountain Kalmia. A shrub or small tree with evergreen leaves. All parts of the plant poisonous to cattle, sheep, and other animals. The honey from the Howers is said to be poisonous: also the flesh of game that has fed npon the leaves or fruit. In woods and on rocky hillsides. Occasionally planted. N. P. to Ont., Ohio. Ind.. Fla., and La.

\section{(is.) Oxydéndrum DC. Sorrel-tree.}

Trees with simple alternate, pinnately veined, serrate, sur leaves, not glandular, but with prominent scattered liristle-like hairs on the midrib beneath: and with cylindrical pith and a central ring-shaped bundle-scar.

Flowers bisporangiate, pentamerous, white, numerous in tcrminal panicled racemes: fruit a capsule.

1. Oxydendrum arbòreum (L.) DC. Sorrel-tree. I small tree with smooth hark and brilliantly red-colored leaves in attumn. Wood hard and close-grained, reddish-hrown: rsed for handles of tools, hearings of machinery, etc. On illsides. Ind., Ohio and Penn. to Va., Fla., and Ala.

\section{Order, Ebenales.}

Sapotaceac. Sapudilla Family.

\section{(i). Bumèlia Si: Bumelia.}

Shrubs or small trees with alternate. simple, pinnately veined, entire leaves: with milky sap; and usually with both terminal and axillary thorns.

Flowers small in axillary fascicles, pentamerous: fruit a Heshy berry with a single seed.

1. Leaves glaharous or nearly so: ohlanceolate to oblone-ovate, 2-,i in. lone. B. lycioides.

1. Leaves tomentose or silky, oblong-ohovate to enneate-obovate, usually ohtuse, 1-:3 in. long. B. lanuginosa.

1. Bumelia lycioìdes (L.) Pers. Buckthorn Bumelia. A shrul or small tree usually with thorns and thornlike spurs and with gray hark. Leaves tardily deciduous. Wood very hard, yellowish-brown. In moist soil. Va. to I11., Mo.. Fla., and Tex. 
․ Bumelia lanuginòsa (Mx.) Pers. Woolly Bumelia. I shruh or rather large tree with persistent leaves. Wood rather soft, weak, yellowish-brown. I11. to Kan., Tex., Ga.. and Fila.

\section{Ebcnaceae. Ebony Family.}

\section{Diospỳros L. Persimmon.}

Trees, ours with alternate, pinnately veined, entire, deciduous leaves, having the petiole jointed to the twig; and with a central bundle scar.

Flowers monosporangiate; fruit a large berry with 4-12 tiat oblong seeds.

1. Diospyros virginiàna L. Persimmon. A handsome tree with hard, dark, furrowed bark. Pith often with cavities. Berry large, oulpy, yellow, exceedingly astringent when green but sweet and edible after frost. Bark astringent and tonic. Wood very hard, heary, strong, and tough, close-grained and dark-colored; used in turnery, for shuttles, plane stocks, and shoe lasts. R. I. to Ohio, Iowa and Kan., Fla., and Tex.

\section{Symplocaceae. Sweetleaf Family.}

\section{Sýmplocos Jacq. Sweetleaf.}

Shrubs or trees with simple, alternate, serrate or repand leaves; with diaphragmed pith showing lenticular cavities; and with axillary buds not superposed.

Filowers bisporangiate, pentamerous, but the stamens numerous: fruit a small, mostly nearly dry drupe.

1. Symplocos tinctòria (L.) L'Her. Sweetleaf. A shrub or small tree, the pith diaphragmed. Flowers bright yellow; fragrant; drupe nutlike. Wood soft, weak, pale red or white. Del. to Fla.. La., and Ark.

Styracaceac. Storax Family.

72. Hàlesia E11. Silverbell.

Shrubs or small trees with simple, alternate, serrate leaves, with diaphragmed pith showing cavities; and with st:perposed axillary buds. 
More or less stellate pubescent; flowers large, white, drooping, in lateral fascicles or short racemes; fruit dry, 2-t-winged.

1. Halesia carolina L. Silverbell. A small tree with diaphragmed pith. Wood soft, light brown. In woods and along streams. Va. to I1l., Fla., and Ala.

\section{Subclass, Tubiflorae. \\ Order, Gentianales. \\ Oleaccac. Olive Family.}

\section{Chionánthus L. Fringetree.}

Shrubs or small trees with opposite, simple, entire deciduous leaves, pinnately veined to the tip : and with pubescent twigs and buds.

Flowers bisporangiate, in large loose panicles; perianth. tetramerous; fruit a drupe.

1. Chionanthus virgínica L. Fringetree. A shrub or small tree with handsome, white, fragrant flowers in drooping panicles. Wood heavy, hard, and light brown. In moist soil. N. J. and Ohio to Fla., Mo., and Tex.

\section{Fráxinus (Tourn.) L. Ash.}

Trees with opposite odd-pinnate leaves without stipules or stipels and with closely crowded bundle scars in a curved line.

Flowers sympetalous or apetalous, bisporangiate or monosporangiate; stamens usually 2); fruit a samara.

1. Leaflets sessile. 2.

1. Leaflets more or less stalked. 3.

2. Leaflets $7-11$, long, gradually tapering to a point, oblong lanceolate. F. nigra.

2. Leaflets short pointed, ovate to obovate. F. crcelsior.

3. Twigs not quadrangular. 4 .

3. Twigs quadrangular: stems sometimes sharply fourangled; leaflets $7-11$, green on both sides, upper ones usually sessile, lower ones short stalked.

4. Twigs pubescent, often velvety. j.

4. Twigs smooth or nearly so. 7 . 
$\therefore$ Leaflets wate to ovate lanceolate; hase nsually trumate or rounded, unsymmetrical: upper surface dark yellow green, soft pubescent beneath: calyx large.

I. profundu.

$\therefore$ Leaflets orate, ovate-lanceolate, or lanceolate, usually. acute at the base; calyx minute. $(i$.

fi. Leaflets pale beneath; ovate to ovate lancelate, $7-11$ : wing of samara terminal or nearly so. li. biltmoreana.

fi. Leaflets green or greenish beneath, ovate-lanceolate to lanceolate, ;-!! : samara with a decurrent wing.

li. pennsylianica.

7. Leaflets pale beneath, ovate to ovate-lanceolate, entire or indefinitely serrate, abruptly acute or acuminate. glabrous or somewhat pubescent: wing of samara terminal. Ii. americana.

†. Leaflets green on both sides, glabrous or somewhat pubescent, usually serrate, lanceolate to ovate-lanceslate, acuminate: wing of samara decurrent on the sides of the slender body. F. lanceolata.

1. Fraxinus quadrangulàta $\mathrm{Mx}$. Hilue Ash. A large tree with 4 -sided or 4 -winged twigs. Jeaflets $7-11$, ovate, ol)long, or lanceolate, acuminate, green on both sides, sharply serrate or serrulate; samara linear-oblong or cuneatc, winged all around, parallel-nerved, the hody extending more than half way to the apex. The inner bark furnishes a blue dye. Wood heavy, hard and valuahle: used for flooring, carriagemaking, etc. Ont., Minn: and Mich. to Ala., Towa and Ark.

.. Fraxinus nigra Marsh. Black Ash. I large tree. Leaflets $7-11$ glabrous, green on both sides, sessile, oblonglanceolate, long acuminate, sharply serrate or serrulate; samara oblong or linear-oblong, parallel-nerved, the body flat, winged all around and extending to or beyond the middle. Wosd heary, soft, dark brown, used for barrel-hoops, baskets. cábinct-work, and interior finish. In swanps and wet soil. Newf. to Man.. Va., and Ark.

3. Fraxinus excelsior L. European 1 sh. $A$ fine hardy tree with bright green leaves. Samara flat, linearoblong. Weeping varietics are in cultivation. Native of Enrope. 
4. Fraxinus profùnda liush. P'umpkin Ash. A large trec with thick, gray; fissured bark and velvety pubescent twigs. Leaflets $7-$ !), orate-lanceolate to oblong-lanceolate, stalked, acuminate, bright green above, paler and pubescent leneath, large. Samara with a flattish body, wing decurrent to below the middle. In swamps. Va. to I11., Mo., Ark., and Pila.

$\therefore$ Fraxinus pennsylvánica Marsh. Red Ash. A large tree with relrety-puhescent twigs. Leatlets 5-!), ovatc, ovatelanceolate, or oblong, acuminate or acute, usually denticulate: licdy of the samara linear margined above by the linear or spatulate decurrent wing. Wood hard, strong, hrown. In moist soil. N. B. to Minn., Fla., and Kan.

(i. Fraxinus lanceolàta Borck. Green Ash. A large tree with glabrous twigs. Leatlets is-9, entire or denticulate. ovate or oblong-lanceolate, acuminate or acute, green on both sides; samara similar to that of the two preceding species. wing ustally spatulate and decurrent on the sides of the body below the middle. Wood rather inferior in value to that of the white ash. In moist soil, on flood-plains, and on l,luffs. Me. to Sask., south to Fla.. Kan., and Tex.

†. Fraxinus biltmoreàna Bead. Biltmore Ash. A tree with the young twigs pubescent. Leaflets $7-9$, ovate to lanceolate, acuminate, entire or obscurely denticulate, more or less mulescent heneath: body of the samara narrowly elliptic. terete: wing linear, or somewhat broadened above, 2-3 times the length of the body. Woodlands and river hanks. Penn. and Ohio to Ga.

\& Fraxinus americàna $\mathrm{L}$. White Ash. I large tree of rapid growth, with glabrouts twigs. Leaflets i-9, ovate, crate-lanceolate, oblong, or rarely slightly obovate, entire or denticulate, pale and often pubescent heneath, acuminate or acute: bucly of the samara terete, not margined, winged only from near the summit, $1-\frac{1}{2}$ the length of the wing. Autumn leaves brown, purple, and salmon. Wood heavy, hard. strong, lrown, tough and elastic, of very great value: widely used in the manufacture of agricultural implements, hoat wars, and carriage shafts; in cabinet-work, for harness work. he ops, haskets, and clothespins. Tn rich soil. X. S. to Minn.. lila.. Kan. and Tex. 
7.5. Forestiera Poir. Adelia.

Shrubs or small trees with simple, opposite, pinnately veined, usually serrate leaves; with brown twigs; and usually with thorns and superposed buds.

flowers dieciuos or imperfectly monosporangiate, in fascicles, or paniculate, from scaly buds; fruit a drupe. .

1. Forestiera acuminàta ( $M x$. ) Poir. Adelia. A shrub or small tree usually with somewhat thorny branches. Wood heavy, soft, yellowish-brown, not strong. On river banks. Ind. to Ga., Mo., Ark., and Tex.

Order, Scrophularilles.

Scrophulariaceae. Figwort Family.

76. Paulòwnia Sieb. \& Zucc. Paulownia.

Trees with opposite petioled, palmately veined, simple Teaves; with superposed axillary buds; and with large white pith, sometimes with cavities.

Flowers in large panicles, bisporangiate, zygomorphic, tetracylic; stamens 4 ; fruit a capsule with numerous winged seeds.

1. Paulownia tomentòsa (Thumb.) Baill. Paulownia. A large rapid-growing tree with violet flowers in terminal panicles. Native of Japan; escaped from cultivation. N. Y. and N. J. to Ga.

Bignoniaceae. Trumpet-creeper Family.

\section{Catálpa Scop. Catalpa.}

Trees with opposite or whorled, simple leaves with entire margins and with prominent green glands in the axils of the veins on the lower side.

Flowers large, white or mottled, in terminal panicles or corymbs, bisporangiate, zygomorphic; stamens usually 2 with 3 prominent vestiges; capsule long and bean-like with numerous winged seeds.

1. Young twigs glabrous or nearly so, leaf-blades downy below; flowers large, white, with 2 yellow stripes inside and spotted purplish brown. 2. 
1. Young twigs and petioles with long hairs; leaf blades glabrous below or nearly so, commonly 3 -lobed or angled, strong-scented, usually with 4 red oval glands at the base of the blade on the upper side; flowers small, yellow with orange stripes inside and violet spots; capsule very slender. C. ovata.

2. Bark thin, flaky; young petioles glabrous or nearly so; wings of seed usually narrowed at the ends, panicle many-flowered. C. catalpa.

2. Bark thick and rough; young petioles usually pubescent; wings of seed usually broad, the threads parallel; panicle few-flowered. C. speciosa.

1. Catalpa catálpa (L.) Karst. Common Catalpa. A tree with thin flaky bark and spreading branches. Wood brown, soft. weak, durable in contact with the soil, much less valuable than that of C. speciosa. The flowers are said to produce irritation of the skin. Gulf States. Escaped in the northern states as far as Ohio and N. Y.

2. Catalpa speciòsa Ward. Hardy Catalpa. A large rapid-growing tree with thick rough bark. Wood light, soft, not strong, brittle, of very coarse texture and brown in color, very durable in the ground; used for railroad ties, posts, furniture and interior finish: also suitable for paper pulp. I1l. to Tenn., Mo., Ark., and Ohio.

3. Catalpa ovàta Don. Japan Catalpa. A small tree, commonly with 3-lobed or angled leaves. Flowers small. From Japan. Often cultivated.

\author{
Subclass, INFERAE. \\ Order, Umbellales. \\ Araliaccae. Ginseng Family.
}

\title{
7. Aràlia I. Aralia.
}

Our species small trees with alternate, bipinnate, decompound, prickly leaves; with prickly twigs: and with about 20 bundle scars in the leaf scar.

Flowers pentamerous tetracyclic, epigynons, in panicled umbels: fruit a small herry. 
1 Aralia spinòsa L. Angelica-trce. A prickly shrub) (11. -mall tree with long-petioled bipinnate leaves. In low ground and alone streams. Sometimes cultivated. Conn. to Fla.. ()!io, Mo., and Tex.

Cornaciat. Dogwoud liamily.

7!!. Córnus (Tourn.) L: Dogwood.

Shrubs or small trees with opposite or rarely alternate. (ntire pimnately reined leaves having the upper two veins curving toward the tip: and more or less parallel with the midrili: and with distinct, exposed, axillary buds.

Flowers in panicles; fruit a bilocular white or blue drupe; cimes self-pruned when the fruit is ripe.

1. Leares alternate; twigs green, smooth; Howers in cymose panicles, drupe blue. C. alternifolia.

1. Leaves opposite, ovate or ovate-lanceolate: drupe globose, white. C. asperifolia.

1. Cornus alternifòlia L. f. Blue Dogwood. A shrub or small tree with smooth, greenish, bitter bark. Wood hard, reddish brown. In rich soil. $\mathrm{X}$. S. to Ga., Ont., Minn.. W. Va., Ala., and Mo.

- Cornus asperifòlia $M x$. Rough-leaf Dogwvod. A tall shrub, sometimes tree-like, with reddish brown twigs. In rich or moist ground and flood plains. Ont. to Fla., Minn.. Kan., and Tex.

\section{(11. Cynóxylon Raf. I)ogwomal.}

Trees or shrulss with opposite, entire, pinnately reined leaves having the upper two veins curving toward the tip and more or less parallel with the mirlrib: and with minute axillary buds hidden under the petiole bases.

Flowers in hearls subtenderl by an involucre of 4 large whitish bracts: fruit a bilocular, red clrupe.

1. Cynoxylon flóridum (I.) Raf. Flowering l)ogwood. A small very ornamental tree, with rough reticulate lark. leaves loright red in autumm. IIood solicl, hard. irown. valuable: used for suntles. The irupes are reputed tw he poisonoms. We. and ()nt. to lila.. Minn.. Mo.. and Tex. 


\section{Nýssa L. Tripelo.}

Trees with alternate leaves, $110 t$-ranked; with :3 rascula bundles in the base of the petiole and with solid diaphragmed pith.

Flowers small, greenish, imperfectly diecions in capitate clusters or short racemes; sometimes solitary; fruit a drupe the stone usually ridged.

1. Leaves mostly entire: carpellate flowers 2-14 in at cluster.

1. Leaves usually dentate: carpellate flowers solitary. I. aquaticu.

2. I.eaves mostly acute or acuminate: carpellate flowers -2-14 together: stone little flattened. I. sylicatica.

‥ Leaves mostly obtuse: carpellate flowers $2-3$ together. stone much flattened. $N$. biflora.

1. Nyssa sylvática Marsh. Common Tupelo. I large tree with horizontal brancines and with rough bark. Leaves bright crimson, scarlet, or purple in autumn. Wood firm, heavy, strong, tough, close-grained, and hard to split: insed for hubs of wheels, pulleys, handles, wooden shoes, woodenware, etc. Not durable if exposed. In rich moist soil. Not easily transplanted. Me. and Ont. to Fla., Mich.. Mo., and Tex.

2. Nyssa biflòra Walt. Southern Tupelo. A small tree similar to the preceding, the base swollen. In swamps and along ponds. $\mathrm{N}$. J. to Va., Fla., and La.

3. Nyssa aquática L. Water Tupelo. A large tree with slender-petioled, oval or ovate, acute or acuminate leaves, usually angular dentate. Wod soft, tough, lizht brown, or nearly white. In swamps. Va. to I11. and IIo.. south to Fla. and Tex.

Order, Rubiales.

Rubiaceac. Madder liamily.

\section{«.). Cephalánthus L. Buttonbush.}

Shrubs or small trees with opposite or whorled, entire. Flowers small, white, densely capitate, tetracyclic: perianth pinnately reined, decidions leaves and prominent stipules. tetramerous: stamens 4 : fruit dry, 1-2-seeded. 
1. Cephalanthus occidentàlis L. Buttonbush. A shrul) or small tree with petioled, ovate or oval, entire acute or acuminate leaves. In swamps and low ground. N. B. to Ont. and Wis., Fila., Tex., Ariz., and Cal.

Caprifoliaceae. Honeysuckle Family.

\section{Vibúrnum (Tourn.) I.. Vihurnum.}

Shrubs or small trees with opposite, simple, serrate or lobed leaves; with :3 bundle scars; and with a terminal bud showing a large and a small pair of scales.

Flowers in componnd cymes, tetracyclic: perianth and andrecium pentamerous: fruit a 1-seeded drupe.

1. Leaves prominently acuminate: petioles slender, margined. $Y$. lentago.

1. Leaves obtuse or merely acute. 2.

2. Petioles slender, rarely margined; leaves glabrous or nearly so. $V$. prunifolium.

2. Veins of the lower leaf surfaces and winged petioles tomentose. $V$. rufidulum.

1. Viburnum lentàgo L. Sheepberry. A shrub or small tree with glabrous acuminate winter buds. Drupe reddish-black, with a bloom, sweet and edible. IVood hard. orange-hrown, ill-smelling. In rich soil. Hudson Bay to Man., N. J., Ga., Ohio, Kan., and Col.

פ. Viburnum prunifòlium L. Black Haw. A shrub of small tree with acnte winter huds, often reddish-pubescent Drupe blue-black, glaucous, sweet and edible. Wood hard, reddish-brown. In dry soil. Conn. to Ga., Mich., Kan., and Tex.

3. Viburnum rufídulum Raf. Sonthern Black Haw. A small tree with elliptic or obovate, mostly obtuse leaves, with brown-tomentose, winged petioles. IVood ill-smelling. On uplands and dry flood plains. N. J. to Mo., Kan., Fla.. and Tex. 


\section{A P P E N D I X.}

\section{KEY TO THE FRUITS.}

The complete fruit at maturity, including the peduncle, is required for determination. The number after each genus refers to the list number.

1. Fruit a cone, a cone-like catkin, a compact aggregate, or an ordinary catkin. 2 .

1. Fruit simple, consisting of a single carpel or set of united carpels, not cone-like or catkin-like, but often clustered. 22.

2. Fruit dry at maturity. 3.

2. Fruit fleshy. 16.

3. Fruit a globular aggregate of flowers on a long slender peduncle. 4.

3. Fruit not globular, except in some true cones, but ovoid or cylindrical, peduncle short, or if rather long then thick and rigid. $\check{\text { s. }}$

4. Fruit an aggregate of dehiscent spiny-pointed capsules with several seeds. Liquidambar. (46).

4. Fruit an aggregate of 1-seeded nutlets, not spinypointed. Platanus. $(47)$.

4. Fruit an aggregate of dry obpyramidal pods showing a prominent calyx at the tip; receptacle with bristles. Cephalanthus. (82).

5. Fruit a true cone with naked seeds, or an aggregate of closed carpels showing stamen, petal and sepal scars on the peduncle. 6 .

5. Fruit a catkin or a cone-like catkin. 19 .

6. Seeds in closed carpels, the cone-like fruit showing stamen, petal, and sepal scars at the base on the peduncle. $T$.

6. Fruit a true cone with naked seeds, not showing stamen, petal and sepal scars on the peduncle. 8 . 
7. (arpels of the fruit forming dehiscent follicles at maturity: the fleshy seeds suspended from the pink or rose tissues of the fruit by slender threads. Magnolia. (12).

7. Carpels samara-iike, dry and indehisent. Liriodendron. (13).

8. Cones with numerous ovuliferous scales, more than 1.5. 9 .

R. Cones with 3-12 ovuliferous scales. 12.

!. Cones crect, their scales deciduous from the persistent axis; ovuliferous scales orbicular or broad. obtuse. Abies. (5).

9. Cones pendulous or projecting from the branch, the scales persistent. 10 .

11. Cone seales woody and thickened at the outer end, clongated, often with a rigicl point, spine, or prickle. Pinus. (7).

10. Cone scales sub-obicular or oval, sometimes with erose or emarginate tips. 11.

11. Cone with subulate leaf-scales at the base. Larix. (6).

11. Cone without subulate leaf-scales at the base, short and ovoid, usually less than $1 \frac{1}{2}$ in. long. Tsuga. (4).

11. Cone without subulate leaf-scales at the base, cylindric or long ovoid, usually 1-6 in. long, scales often with erose or emarginate tips. Picea. (3).

12. Carpels spirally arranged. 13.

1.2. Carpels opposite. 14.

1:i. Cone globose, the scales closely compressed on the outside, seeds not winged. Taxodium. (2).

13. Conc ovoid, with subulate leaf-scales at the base, the carpellate scales loose and open; seeds somewhat winged. Larix. (6).

14. Carpels imbricate, not shield-shaped, with 1-3 (usually 2 seeds). 15.

14. Carpels shield-shaped, with 2-3 seeds, more or less winged. Chamaecyparis. (10).

1.). Carpels 6-8, the four upper fertile. Thuja. (8).

15. Carpels $4-6$, the two upper fertile. Libocedrus. (9).

16. Fruit globose, over 2 in. in diameter. 17.

16. Fruit elongated, ovoid or cylindrical. 18. 
17 Fruit green or yellowish-green, 3-5̌ in. in diameter.

Toxylon. (52).

17. Fruit all aggregate of red drupes projecting beyond the persistent periantlis. Papyrius. (53).

18. Fruit very jucy, consisting of a catkin-like aggregate of small fleshy Howers. Morus. (51).

18. Fruit an aggregate of carpels, the ripe follicles dehiscent, and the seeds pendant from slender threads. Magnolia. (1:).

18. liruit a small blue berry-like cone. Juniperus. (11).

19. Catkin composed of capsules with numerous seeds having tufts of cottony hairs. 20.

19. Catkin containing 1 -seeded nutlets, achenes, or samaralike nutlets. 21.

20. Capsule with a little cup at the base. Populus. (64).

20. No cup at the base of the capsule but 1 or 2 little glands may be present. Salix. (65).

21. Fruiting catkin with leaf-like bracts; nutlets with ridges, somewhat compressed. Carpinus. (57).

21. Fruiting catkin hop-like, with bladder-like bracts; nutlets somewhat compressed, ridges inconspicuous. Ostrya. (58).

21. Fruiting catkin woody and cone-like,- nutlets small compressed, winged or wingless. Alnus. (60).

21. Fruiting catkin compact with rather thin scale-like bracts, cone-like; nutlets compressed, membranouswinged: samara-like. Betula. (59).

92. Fruit a dry or nearly dry samara, nut, achene, bean, or capsule, or a dry clrupe. 2:3.

22. Fruit fleshy, indehiscent. 55.

23. Fruit or the peduncle prominently winged. 24 .

23. Fruit and peduncle not with wings. 30 .

24. Peduncle of the fruit cluster with a large wing; fruit a dry drupe. Tilia. (20).

24. Peduncle not winged; fruit a true samara, or with 1 or more prominent wings. 25 .

25. Fruit with a prominent spine-like beak at the tip and with 2 or 4 wings, large. Halesia. (72).

25. Fruit not with a prominent spine-like point. 26 . 
21. Fruit double with :2 cavities and 2 large wings.

Acer. (41).

26. Samara with a wing all around or with a single wing at the end. 27.

27. Samara circular, oval, or broader than long. 28.

27. Samara elongated. 29.

2. W. Wing extending around the fruit, very veiny, glabrous: long-peduncled, calyx not present or very inconspicnous; cavities 2, 1 usually empty. Ptelea. (18).

2. Wing notched at the apex, usually veiny: fruit longpeduncled, calyx present; cavity with 1 seed.

Ulmus. (tr).

28. Wing on the two sides of the fruit, with 2 stigmas at the apex; fruit sessile, small. Betula. (59).

-9.9. Wing extending as far below the central seed as beyond it. Ailanthus. (19).

29. Wing terminal or extending along the sides of the seed but not beneath it. Fraxinus. (T4).

30. Fruit a dehiscent bean, follicle, or capsule, usually with several seeds. 31 .

30. Fruit an indehiscent nut, achene, or dry drupe with 1 cavity and 1-2 seeds; often partly or completely enclosed in a cup or husk. 47.

31. Fruit a bean or legume with 1 cavity and 2 sutures; seeds not winged. 32 .

31. Iiruit a capstule; if bean-like then with 2 cavities. 35.

:32. Bean an inch or more broad, mostly with pulp. 39.

:3.). Bean about $\frac{1}{2}$ in. broad, without pulp. 34.

:i:) Bean very hard and thick, seed 3 in. long.

Gymnocladus. (31).

3:). Bean not very woody, thin, seed less than $\frac{1}{2}$ in. long. Gleditsia. (30).

34. Bean with a prominent ridge on each side of one suture, apex long-acute. Cercis. (25).

$3 t$. Bean with the 2 sutures nearly alike, apex mucronate, or with a slender point, sometimes bristly.

Robinia. (33).

:34. Bean usually irregular and somewlat constricted into joints, apex abruptly acute, calyx containing long filaments. Cladrastis. (32).

i.. Seed with wings or a tuft of cottony hairs. $3 f$. 
35. Seed without wings or hairs. 39.

36. Seed with a tuft of hairs, capsule small. 37.

36. Seed with wings, the wings sometimes with a fringe of long hairs. 38.

37. Capsule with a little cup at the base. Populus. (64).

37. No cup at the base of the capsule but 1 or 2 little glands may be present. Salix. (65).

38. Capsule very long, wings of seed with a fringe of hairs. Catalpa. (77).

38. Capsule short, wing of seed without hairs.

Paulownia. ( 76$)$.

39. Seeds very large, $\frac{1}{2}-2$ in. in diameter. 40 .

39. Seeds much less than $\frac{1}{2}$ in. in diameter. 41 .

40. Seed smooth with a large light spot at one end, without ridges or angles. Aesculus. (40).

40. Seed with two or more vertical ridges, without a special light spot - a nut in an enclosing husk which may be mistaken for a capsule. Hicoria. (61).

41 Seeds with a fleshy, scarlet aril, capsule lobed.

Euonymus. (35).

41. Seeds without an aril. 42.

42. Seeds 1 or 2, capsule not bladdery. $4:$.

42. Seeds several to many. 44.

43. Capsules small without a cup at the base.

Zanthoxylum. (17)

43. Capsule woody, $\frac{1}{2}$ in. long, with prominent cup at the base; seeds 2, oblong. Hamamelis. (45).

43. Capsule splitting tardily, with the prominent calyx persistent at the tip. Cephalanthus. (82).

14. Capsule triocular, large, bladdery. 45.

44. Capsule with 5-many cavities, small. 46.

45. Capsule 3 -lobed at the tip, with 3 styles, usually widest at the middle or toward the outer end.

Staphylea. (37).

45. Capsule with a long, acute tip, with a single style, widest below the middle. Koelreuteria. (39).

46. Capsules mostly woody, oblong, puberulent; in corymbose or umbellate clusters. Rhododendron. (66). 46. Capsules depressed-globose, somewhat 5-lobed; in corymbose or umbellate clusters. Kalmia. (67). 
11i. Capsules ovoid-pyramidal, ".-angled; in large panicled racemes. Oxydendrum. (6R).

17. Fruit a dry drupe, or drupe-like: exocarp softer than the bony endocarp. ts.

17. Fruit a nut or achene, the pericarp not in 2 layers; often partly or completely enclosed in a cup or husk. 19.

k. Fruit globose, ? in. or more in dianceter, on winged peduncles. Tilia. (20).

IR. Fruit obliquely ovoid, compresserl, ridged on the back and covered with prominent soft processes.

Planera. (19).

18. Firuit subglobose, nearly symmetrical, $\frac{1}{8}$ in. long, pubescent, red. Rhus. (42).

1R. Fruit subglobose, nearly symmetrical, \& in. long; light gray, stone striate. Toxicodendron. (43).

1․ Fruit obliquely oblong or oval, compressed, gibbous, $1 / 8$ in. long, reticulate-veined. Cotinus. (44).

49. Nut sharply 3 -angled; usually 2 together in the 4 valved bur. Fagus. (54).

19. Nut not 3-angled. 50 .

50. Nut less than $\frac{1}{1}$ in. long, somewhat compressed. 51.

.it. Nut large, more than $\frac{7}{2}$ in. long, or if not then circular in cross-section. 52.

i1. Nut with ridges; fruiting bract 3-cleft and incised.

Carpinus. (5i).

i1. Ridges of the nutlet inconspicuons, fruiting bract bladder-like. Ostrya. (58).

.2. Nut with ? or 3 prominent ridges, sometimes with rough wrinkles. 53 .

.i). Nut not with ridges. 5t.

ii). Nut rugose or sculptured; husk indehiscent.

Juglans. (62).

53. Nut smooth or angled, husk at length splitting into segments. Hicoria. (61).

if. Nut ovoid-oblong or subglobose; cup with imbricated, more or less united bracts. Quercus. (56).

if. Nut plano-convex or roundèd; bur globose and very prickly. Castanea. (5.). 
54. Seed, which may be mistaken for a nut, not showing a style, large and shining; capsule splitting into :3 valves. Aesculus. (40).

5.5. Fruit a pome, the carpels enclosed by an adnate, perigynous disk or hypanthium. 56 .

55. Fruit a berry, or berry-like, with several seeds. 60.

5.). Fruit a drupe, or drupe-like, with a stone or pit and with 1 or rarely 2 seeds. 66.

i6. Ripe carpels of the pome papery or leathery. 5.

j6. Ripe carpels bony. Crataegus. (26).

77. Pome small and berry-like. 58.

ii. Pome large, fleshy like the apple. 59.

if. Pome scarlet when ripe, cavities not more than 5.

Sorbus. (21).

58. Pome purplish-red to purplish-blue when ripe, cavities usually 10. Amelanchier. (25).

59. Seeds not more than 3 in each cavity; pome tapering into the peduncle; flesh with grit-cells. Pyrus. (22).

59. Seeds not more than 3 in each cavity; pone sunk in at both ends, its flesh without grit-cells. Malus. (23).

59. Seeds many in each cavity, flesh of pome hard.

Cydonia. (2t).

60. Berry large, very much elongated, green with yellow pulp and large brown seeds. Asimina. (14).

60. Berry ovoid or globose. 61 .

61. Berry about 1 in. in diameter, reddish-yellow, with 4-12 large, flat, hard seeds and with the enlarged calyx at the base. Diospyros. (70).

61. Berry not over $\frac{2}{3}$ in. in diameter. 62 .

62. Fruit inferior, showing scars or parts of the perianth and stamens at the tip. 63.

62. Fruit superior, showing only the style at the tip, with scars or perianth parts if present at the base. 64.

(i3). Fruit scarlet, cavities ¿. Sorbus. (21).

63. Fruit purplish-red to purplish-blue, cavities usually 10. Amelanchier. (25).

(i).) Fruit black, small, cavities 5. Aralia. (78).

64. Fruit really a berry-like blue cone, showing the carpel tips on the sides, on close inspection. Juniperus. (11). 
(i). Firuit not a modified cone, but a true berry. (i.).

(i.). Rerry-like drupe usually red or yellowish, with $4-\varepsilon$ bony or crustaceous nutlets. Ilex. (36).

(i.). Berry-like drupe black, with $2-4$ seed-like nutlets.

Rhamnus. (34).

(i.j. Berry very saponaceous, dark; seeds 1-3, crustaceous, globose. Sapindus. (38).

(i..) Berry black, with 1 erect, shining seed. Bumelia. (69).

(i5) Berry dark blue with 1 seed, $\frac{1}{2}-\frac{3}{4}$ in. in diameter.

Persea. (15).

(6). Fruit large, usually 2 in. or more in diameter: stone or nut deeply pitted, corrugated, or sculptured, usually $1 \frac{1}{2}$ in. or more long. 67 .

66. Stone not deeply pitted, corrugated, or sculptured, not more than $\frac{3}{4}$ in. long; if reticulated, then less than $\frac{1}{2}$ in. long. 68 .

(ii. Flesh of fruit black or greenish, hard, with strong odor: seed in the nut much wrinkled. Juglans. (62).

67. Drupe pubescent, its flesh sweet; seed in the stone smooth. Amygdalus. (28).

(ic. Drupe white-waxy, less than $\frac{1}{4}$ in. in diameter, globose, tuberculate. Myrica. (63).

(ix. Drupe not white-waxy, if somewhat resinous then much larger. 69.

(i!) Fruit superior, showing only a style or its scar at the tip but usually the remains of a calyx below. 70 .

6.9. Fruit inferior, showing sepals, petals, and stamens or their remains or scars at the tip. 75 .

7). T)rupe with red acid hairs, small. Rhus. (42).

7). Drupe light gray, small, stone striated.

Toxicodendron. (43).

70. Drupe not with red acid hairs nor gray with striated stone. 71 .

71. Drupe narrowly oblong, about 1 in. long.

Forestiera. (75).

71. Drupe globose, oval, or globose-oblong. 72.

$7 \cdot$. Stone ridged and reticulated, showing prominent teeth in cross-section. Celtis. (50).

72 . Stone smooth, or if somewhat roughened then with a prominent suture all around. 73 . 
73. Fruiting pedicel much thickened below the prominent calyx base, red; drupe oblong-globose, blue.

Sassafraz.

73. Fruiting pedicel somewhat thickened, red or reddish, the drupe-like berry dark blue, $\frac{1}{2}-\frac{3}{4}$ in. in diameter. Persea. (15).

i:3 Fruiting pedicel not thickened below the calyx or if so the fruit not blue. $T 4$.

it. Fruit light greenish-yellow; Hesh with a sickeningsweet odor and a sticky juice: embryo in a large kernel; a gymnospermous seed. Girłzgo. (1).

74. Drupe often large and sweet, stone with a suture all around, often flattened. Prunus. (27).

74. Drupe with a $4-6$ lobed calyx; oblong-ovate, blue; endosperm large with a small embryo in the center. Chionanthus. (73).

74. Fruit really a small black berry: seed shining, with the hilum at the base. Bumelia. (69).

75. Stone with 2 cavities and 2 seeds. 76 .

75. Stone usually with 1 seed. 77 .

76. Drupe white or blue. Cornus. (79).

76. Drupe red. Cynoxylon. (80).

7 . Stone with 1 cavity and 1 seed, grooved and somewhat compressed; drupe glabrous, blue or nearly black. Nyssa. (81).

ii. Fruit with prominent nerves and ridges, with is sepal-tips, oblong-ovate, pubescent, nearly dry, nutlike. Symplocos. (71).

7i. Stone 1-seeded, sometimes flattened; drupe with a prominent stylar beak, blue, black, or red. 


\section{A GENERAL CLASSIFICATION OF THE WOOD OF TREES INCLUDED IN THE MANUAL.}

1. Wood without annual rings, but with scattered vascular bundles. Monocotylae.

(No trees in our region).

B. Wood in a growing cylinder, showing annual rings, with a central pith.

I. W'ood non-porous, the cells not visible or conspicuous in cross section even with a hand lens, there being no wood ressels; annual rings distinct by denser dark-colored bands of late wood. Ginkgoeae and Coniferae.

1. Resin-ducts present in cross section.

a. Without distinct heartwood. Picea.

b. with distinct heartwood. Larix, Pinus.

-2. Resin-ducts not present in the wood.

a. Resin-ducts in the pith. Ginkgo.

b. Pith without resin-ducts.

(a) Without distinct heartwood. Abies, Tsuga.

(b) With distinct heartwood, either of a different color or of a deeper shade than the sapwood.

(a)) Without a sharp demarcation in color between the lieartwood and sapwond, the one fading gradually into the other. Taxodium, Chamaecyparis, Thuja.

(1)) With a clear demarcation in color hetween the heartwood and sapwood. Libocedrus, Juniperus.

II. IVood porous; the pores, or true wood vessels, being visible in cross section with a hand lens or to the naked eye. Dicotylae.

1. Wood diffuse-porous; pores numerous and usually not plainly visible in cross section 
without a hand lens; annual rings distinct by a fine line of denser late wood cells, often quite indistinct; pores scattered thru the annual ring; no zone or no very definite ring of collected pores in the early wood. Magnolia, Liriodendron, Persea,- Tilia, Sorbus, Pyrus, Malus, Cydonia, Amelanchier, Crataegus, Prunus, Amygdalus, Euonymus, Ilex, Staphylea, Aesculus, Acer, Hamamelis, Liquidambar, Platanus, Fagus, Carpinus, Ostrya, Betula, Alnus, Juglans, Myrica, Populus, Salix, Rhododendron, Kalmia, Oxydendrum, Symplocos, Halesia, Forestiera, Cornus, Cynoxylon, Nyssa, Cephalanthus, Viburnum.

a. Among the above, those having lighl, colored or dark heartwood are the follow. ing: Persea, Prunus, Amygdalus, Liqui dambar, Fagus, Juglans, Oxydendrum. Halesia.

2. Wood ring-porous, the pores or wood vessel:s numerous and usually visible in cross section without a hand lens; annual rings distinct by a zone or ring of large pores in the early wood alternating with a denser zone of late wood containing fewer or smaller pores. Asimina, Sassafras, Zanthoxylum, Ptelea, Ailanthus, Cercis, Gleditsia, Gymnocladus, Cladrastis, Robinia, Rhamnus, Sapindus, Koelreuteria, Rhus, Toxicodendron, Cotinus, Ulmus, Planera, Celtis, Morus, Toxylon, Papyrius, Castanea, Quercus, Hicoria, Bumelia, Diospyros, Chionanthus, Fraxinus, Paulownia, Catalpa, Aralia.

a. Among the above, those having highly colored or dark heartwood are the following: Asimina, Cercis, Gleditsia, Gymnocladus, Robinia, Rhus, Toxicodendron, Cotinus. Morus, Toxylon, some species of Quercus, Hicoria, Diospyros, Catalpa, Aralia. 


\section{GLOSSARY.}

Achene. I one-secded dry indehiscent fruit with a tightly fitting pericarp around the seed.

Aetinomorphic. Raclially symmetrical; a flower or organ which can be cut into similar equal halves by two or more planes.

Acuminate. Tapering gradually to the apex.

Acute. Sharp pointed.

Adnate. An organ adhering to another; an anther attached longitudinally to the end of the filament.

Adventive. Apparently becoming naturalized.

Alternate. With a single leaf or other organ at each node. Ament. A slender usually flexible spike of flowers, as in the willows.

Indrecium. The whole set of stamens in a flower.

Anther. The spore-bearing part of a stamen; the part which finally contains the pollen sacs.

Anthesis. The period of flowering.

Apetalous. Without petals.

Appressed. Lying close against another organ.

Aril. A fleshy organ around the hilum.

Auricled. With ear-like lubes.

Axillary bud. A bud in the axil of a leaf.

Axil." The point of a stem just above the hase of the leaf.

Axile. In the axis of an organ.

Baccate. Berry-like.

Berry. I fruit with a fleshy or pulpy pericarp.

Bilocular (2-locular). Having two cavities.

Bisporangiate. Having both microsporangia and megasporangia: having both stamens and carpels.

Blade. The expanded partinf a leaf.

Bract. I small, rudimentary, or imperfectly developed leaf. Bucl scale. (One of the scales in the winter bud.

Bundle scar. I scar in a leaf scar produced by a vascular bundle or strand of bundles.

Caducous. Falling away very soon after development.

Calyx. The outer set of sterile floral leaves; the whole set of sepals. 
Canescent. With gray or hoary fine pubescence.

Capitate. Arranged in a head.

Capsule. A dry fruit of two or more carpels usually dehiscent by valves or teeth.

Carpel. The megasporophyll of a seed plant; the modified leaf or stem bearing the ovules.

Carpellate. Having only carpels, or carpellate flowers.

Catkin. Same as ament.

Cauline. Pertaining to the stem.

Chaff. Dry thin scales.

Chlorophyll,' The green coloring matter of plants.

Choripetalous. Having the petals separate or free.

Ciliate. Provided with marginal hairs.

Ciliolate. Ninutely ciliate.

Conduplicate. Folded lengthwise.

Cone. I primitive flower as the carpellate cone of the pine. Connate. Similar organs more or less mited.

Convolute. Rolled around or rolled up longitudinally:

Cordate. Heart-shaped.

Coriaceous. Leathery.

Corolla. The inner set of sterile, usually colored, Horal leaves: the whole set of petals.

Cotyledon. A leaf-like organ of the embryo in the seed.

Crenate. With rounded teeth.

Crenulate. Minutely crenate.

Cuneate. Wedge-shaped.

Cuspidate. With a sharp stiff point.

Cyme. An inflorescence of the determinate type, the central Hower developing first.

Deciduous. Falling away at the end of the growing period. Decompound. More than once compound.

Decurrent. Applied to an crgan extending along the sicle of another.

Dehiscence. The opening of an ovulary, sporangium, or pollen sac for the discharge of the contents.

Deltoid. Broadly triangular.

Dentate. With outwardly projecting teeth.

Diadelphous. Haring the stamens united into two sets.

Diaphragm. A septum or transverse plate in the pith or other parts. 
Dichotomous. Two-forked.

Didymous. Twin-like.

Diecious. Having the microsporangiate or staminate fluwers and the megasporangiate or carpellate flowcrs on separate plants.

Digitate. Diverging like the spread fingers.

Dissected. Divided into many segments.

Divided. Cleft to the base or to the midrib.

Drupe. A simple usually indehiscent fruit with fleshy exocarp and hony endocarp.

Dwarf branch. A highly specialized and reduced shoot on a twig, as in the pine and larch.

Emarginate. IVith a notched apex.

Embryo. In incipient plant in the seed.

Embryo sac. The female gametophyte, contained in the ovule of seed plants.

End bud. The bud at the end of the twig in case the terminal bud is self-pruned.

Endocarp. The inner layer of the pericarp.

Endosperm. The nourishing tissue developed around the embryo in the female gametophyte of the anthophyta.

Entire. Without teeth, serrations or lobes.

Ephemeral. Continuing for only a day or less.

Epigynous. Having the calyx, corolla, and andrecium above the ovulary.

Evanescent. Disappearing early.

Exocarp. The outer layer of the pericarp.

Exserted. Extending heyond surrombling organs or parts. Extrorse. Facing outwards.

Falcate. Scythe-shaped.

Fertile. Bearing spores or secds.

Fertilization. The conjugation of the male and female gametes.

Feticl. Ill-smelling.

Filament. The stalk of an anther.

lilower. The modified spore-locaring branch of the seed plants. lioliaceous. Leaf-like.

Follicle. I simple fruit dehiscent along one suture.

Fruit. The ripe ovulary with the sceds and whatever parts are consolidated with it. 
Fugaceous. Falling soon after development.

Fugitive. Plants not native, lut recurring here and there, without apparently becoming established.

Gamete. A sexual cell.

Gametophyte. The sexual generation of plants.

Geophilous. Earth-loving; growing partly or completely subterranean.

Gibbous. Enlarged or swollen on one side.

Glabrate. Nearly without hairs.

Glabrous. Without hairs.

Gland. A group of secreting cells.

Glaucous. Covered with a bluish or white bloom.

Globose. Spherical or nearly so.

Glutinous. Sticky or gummy.

Gynecium. The whole set of carpels in a flower.

Habit. General aspect.

Habitat. The place where a plant grows.

Hastate. Arrow-shaped with the basal lobes diverging.

Head. A dense, round inflorescence of sessile or nearly sessile flowers.

Herbaceous. Leaf-like in texture and color.

Hirsute. Having rather coarse stiff hairs.

Hispid. With bristly stiff hairs.

Hydrophyte. A water plant.

Hypanthium. Any enlargement or special derelopment of the

torus, in a flower, on which the sepals, petals, and stamens are borne; a perigynous disk.

Hypogynous. Having the calyx, corolla, and andrecium below the gynecium.

Imbricated. Overlapping.

Imperfect. Monosporangiate flowers; having only stamens or only carpels.

Incised. Cut into sharp lobes.

Included. Not projecting beyond surrounding parts.

Indehiscent. Not opening.

Inequilateral. With unequal sides.

Inferior. Situated or arising below other urgans.

Inflorescence. The flower cluster of a plant and its mode of arrangement. 
Internode. The part of a stem between two successive nodes. Introrse. Facing inwards.

Involucre. A whorl of bracts stubtending a flower or Hower cluster.

Involute. Rolied inwardly:

Irregular. A flower with one or more organs of a set minlike the others.

Isohilateral. A flower or organ which can be cut into equal halves by two planes, the halves of the one heing unlike those of the other.

Lanceolate. Lance-shaped.

Lateral bud. An axillary bud, any bud not the terminal bud of a branch.

Latex. The milky sap of certain plants.

Leatlet. One of the divisions of a compound leaf.

Leaf scar. The scar or cicatrix formed where the petiole of a leaf separates from the stem or twig.

legume. I simple, dry fruit dehiscent along both sutures.

Lenticel. I small usually oval or rounded spot on the bark of a twig or stem, produced by a special tissue of cells under a stoma and breaking through the epidermis.

limb. The expanded part of a petal, sepal, or sympetalous corolla.

Linear. I long and narrow organ with the sides nearly parallel.

Lobed. Divided to about the middle or less.

I.oculicidal. A capsule which splits longitudinally through the middle of the back of each carity or component carpel.

Medullary rays. Strips of cells passing radially through the wood from the pith or annual rings to the bark.

Megaspore. The larger of the two kinds of nonsexual spores produced in the flower. The megaspore develops into the female gametophyte.

Megasporangium. A sporangium which produces megaspores; the ovule in seed plants.

Membranous. Thin and rather soft and pliable.

Mesophyte. A land plant adapterl to ordinary conditions of moisture. 
Microspore. The smaller of the two kinds of non-sexual spores produced in the Hower. The microspore develops into the male gametophyte.

Microsporangium. A sporangium which produces the microspores; the incipient pollen sacs in the seed plants.

Midrib. The central rib of a leaf or other organ.

Monadelphous. Stamens with united filaments.

Monecious. Having staminate and carpellate flowers on the same plant.

Monosporangiate. Flowers bearing only one kind of spores;

a flower with only stamens or carpels.

Mucronate. With a sharp abrupt point.

Mucronulate. Slightly mucronate.

Naturalized. Plants not indigenous to a region but having become established as part of the flora.

Natural pruning. The process by which dead twigs and branches are separated from the tree by the formation of a collar or callus.

Nectary. A nectar-secreting organ.

Node. The place where two internodes join, normally with a single leaf or more.

Nut. An indehiscent one-seeded fruit with a hard or bony pericarp.

Nutlet. A very small nut.

Obcordate. Inversely heart-shaped.

Oblanceolate. Inversely lanceolate.

Oblong. Somewhat longer than broad with the sides nearly or quite parallel.

Oosphere. The unfertilized egg; the female gamete.

Oospore. The fertilized egg.

Ovary. The female organ of reproduction; an egg-producing organ.

Ovate. Shaped like the longitudinal section of a hen's egg. Ovulary. The ovule-bearing part of a closed carpel or set of carpels.

Ovule. The megasporangium of a seed plant which later develops into a seed.

Ovum. The egg or oosphere. 
Palmate. Diverging like the fingers of a hand.

Panicle. A compound inflorescence of the racemose type usually of pyramidal form.

Parasitic. Growing upon other living plants or animals and absorbing their juices and tissues as food.

Parietal. Borne on the wall of the ovulary, or pertaining to it. Parted. Deeply cleft.

Pedicel. The stalk of a flower in a flower cluster.

Peduncle. The stalk of a flower or flower cluster.

Pellucid. Transparent.

Peltate. Shield-shaped, as a leaf with the petiole attached at or near the centre of the blade.

Pentacyclic Having five cycles.

Pentamerous. Five-parted.

Perfect. A flower having both stamens and carpels.

Perfoliate. Leaves so clasping the stem as to appear as if pierced by it.

Perianth. The calyx and corolla taken collectively.

Pericarp. The wall of a fruit; the carpel wall.

Perigynous. Having the sepals, petals and stamens borne on a disc surrounding the gynecium.

Persistent. Remaining attached after the growing period.

Petal. One of the leaves of the corolla.

Petiole. The stalk of a leaf.

Pilose. With long soft hairs.

Pinna. The primary divisions of a pinnately compound leaf. Pinnate. Leaves divided into leaflets or segments along a common axis.

Pinnatifid. Pinnately cleft to the middle or beyond.

Pinnule. I division of a pinna in a compound leaf.

Placenta. The ridge or surface bearing the ovules.

Plicate. Folded like a fan.

Plumose. Resembling a plume or feather.

Plurilocular. Having several or many cavities.

Pollen grain. The male gametophyte of seed plants.

Pome. The fruit of the apple and related plants, with an adnate fleshy perigynous disc.

Prickle. A stiff sharp-pointed outgrowth from the epidermis. Puberulent. With very short hairs.

Pubescent. Hairy, especially with finc and soft hairs.

Punctate. With translucent dots or glands. 
Raceme. An elongated inflorescence with each flower on a peduncle.

Rachis. The axis of a compound leaf, spike, or raceme.

Receptacle. The end of the flower stalk bearing the floral organs.

Reflexed. Bent backward abruptly.

Regular. Having the parts of each set alike in size and shape.

Reniform. Kidney-shaped.

Repand. With a more or less wavy margin.

Retuse. With a shallow notch at the end.

Revolute. Rolled backward.

Rotate. With a flat round corolla; wheel-shaped.

Sagittate. Shaped like an arrow head.

Samara. A simple indehiscent winged fruit.

Scabrous. Rough.

Scale. A highly modified dry leaf as in the winter bud of most plants; also a dry, flat, more or less membranous outgrowth from a leaf or stem.

Scurfy. Covered with scurf, minute membranous scales, as in Chenopodium.

Scarious. Thin, dry, and translucent, not green.

Seed. The matured and modified ovule with a dormant embryo.

Self-pruning. The process by which living buds or twigs are naturally separated from the plant.

Self-pruning scar. A scar produced where a twig or bud has been self-pruned.

Sepal. One of the leaves of a calyx.

Septicidal. A capsule which splits longitudinally through its partitions thus dividing it into its component carpels.

Serrate. With teeth projecting forward.

Sessile. Without a stalk.

Sinuate. With strongly wavy margins.

Sinus. The space between two lobes.

Spermary. The male reproductive organ.

Spermatozoid or sperm. The male gamete.

Spike. An elongated inflorescence with sessile or nearly sessile flowers. 
Spine. A sharp thorn-like organ not representing a stem in origin but a leaf or part of a leaf, as the spines on the leares of the Christmas holly.

Spore. A modified reproductive cell.

Sporophyte. The nonsexual generation of plants.

Spur. A short stunted brancl not representing a true dwarf branch and not ending in a thorn-like point; any projecting appendage of a flower looking like a spur.

Stamen. The organ of a flower which preduces microsporangia, which contain the microspores which later develop into pollen grains.

Staminate. Having only stamens or staminate Howers. Stellate. Star-like.

Sterigma. A small, short, pey-like projection on which certain leaves, spores, etc., are borne.

Sterile. Not producing spores or seeds.

Stigma. The upper part of the carpel: a special organ of the Angiosperms to catch the pollen grains.

Stipel. The stipule of a leaflet.

Stipular scar. The mark made on the bark by deciduous stipules.

Stipular spine. A spine representing a stipule or having the position of a stipule.

Stipules. Bract-like appendages at the base of the petiole of many leaves.

Strigose. With stiff appressed or ascending hairs.

Style. The narrw top of the carpel or mited carpels between the ovulary and stigma.

Subulate. Awl-shaped.

Succulent. Soft and juicy:

Superposed. Placed one above the other.

Sympetalous. With petals more or less united.

Synantherous. Having the stamens mited by their anthers. Syncarp. A lleshy aggregate fruit.

Terete. Circular in, cross section.

Terminal buci. The hud at the morphological tip of the twig. Ternate. Divided into three segments; arranged in threes. Tetracyclic. A flower with four cycles.

Tetradynamous. With four long stamens and two short oncs as in the Prassicaceae. 
Tetramerous. Four-parted.

Thorn. A highly modified sharp-pointed branch.

Thorn-like spur. A short stunted branch ending in a sharp point or thorn.

Tomentose. Covered with dense wool-like hairs.

Triadelphous. Having stamens united by their filaments into three bundles.

Trilocular (3-locular). With three cavities.

Trimerous. Three-parted.

Truncate. Terminating abruptly by a nearly straight edge or surface.

Two-ranked. Disposed in two vertical rows along the twig: with the third leaf in line with the first.

Umbel. A determinate inflorescence with all the peduncles or pedicels arising from the same point.

Undulate. With wavy margins.

Unilocular (1-locular). With one cavity.

Utricle. A one-seeded fruit with a loose pericarp.

Valvate. Meeting by the margins in the bud, not overlapping; dehiscent by valves.

Vascular bundle. The conducting strands in the plant body composed of wood and hast in which water and food materials are conducted through the roots, stems and leaves.

Vein. One of the branches of the vascular portion of leaves or other organs.

Venation. The arrangement of the veins.

Vernation. The arrangement of the leaves in the bud.

Versatile. An anther attached at or near its middle to the filament.

Verticillate. Whorled.

Villous. With long, soft hairs not matted together.

Whorled. A group of three or more similar organs radiating from a node.

Winged. With a thin expansion.

Xerophyte. A plant adapted to desert conditions.

Zygomorphic. A flower or organ which can be cut into similar halves by only one plane.

\section{H. HILL Lignan}





\section{INDEX.}

PAGE

PAGE

Abies .............. 48

Buckthorn, see Bumelia. 119

Acer

Bumelia ............. 119

Adelia

124

Burning-bush, see Wahoo 81

Aesculus ............ 83

Butternut ........... 110

Ailanthus ........... 58

Buttonbush

127

Alder

Alnus

105

Amelanchier .......... 62

Amygdalus

Buttonwood, see Syca-

more ............. 90

Canoe Birch, see Paper

Birch

Angelica-tree ......... 126

Carpinus ............ 103

Apple ............... 60

Apricot $\ldots \ldots \ldots \ldots \ldots$ is

Carya, see Hicoria..... 106

Aralia ............. 125

Arborvitae .......... 52

Ash ................ 121

Asimina $\ldots \ldots \ldots \ldots \ldots, 56$

Castanea ............. 95

Catalpa ............. 124

Cedar, see Juniper..... 54

Celtis ............... 93

Cephalanthus ........ 127

Aspen ............... 113

Bald-cypress $\ldots \ldots \ldots \ldots 46$

Basswood, see Linden... 59

Bay ............... 56

Bayberry ............ 110

Beech ............... 95

Betula .............. 104

Cercis .............. 78

Chamaecyparis ....... 53

Cherry ............... 74

Cherry Birch, see Sweet Birch ............ 10.

Chestnut ............ 95

Birch .............. 104

Bitternut ............ 108

Black Gum, see Tupelo.. 127

Black Haw ......... 128

Black Locust, see Conmon Locust ........ 80

Black Oak ........... 101

Bladdernut ........... 82

Blue-beech .......... 103

Boxelder ............ 87

Chinquapin $\ldots \ldots \ldots \ldots .96$

Chionanthus ......... 121

Cloke Pear, see Pear... (60)

Cladrastis ............ 79

Coffee-bean ......... 79

Cornel, see Dogwood.... 126

Cornus ............. 126

Cotinus ........... 89

Cottonwood .......... 112

Crab-apple .......... 60

Crataegus ............ 62

Buckeye ............ 83

Cydonia

Buckthorn

Cynoxylon 
PAGE

PAGE

Cypress .......... 53 Juniper .......... it

Diospyros .......... 120 Juniperus ......... it

Dogwood ......... 126 Kalmia .......... 118

Elm .............. 91 Kentucky Coffeetree, see

Euony:mus ........ $81 \quad$ Coffee-bean ....... 79

Fagus $\ldots \ldots \ldots \ldots \ldots \ldots$ 9.) Koelreuteria $\ldots \ldots \ldots \ldots .83$

Fir ............. th Larch ........... 49

Forestiera . . . . . . 124 Larix . . . . . . . . 4 ?

Fraxinus .......... 121 Laurel, see Rhododen-

Fringetree ......... 121 dron and Kalmia..... 118

Ginkgo ............ $4 t i$ Libocedrus ......... 53

Gleditsia ........... is Liquidambar ........ 90

Great Laurel, see Rhodo- Linden ............ 58 dendron ........... 11s Liriodendron ......... 5.

Gymnocladus ........ 79 Locust ........... 80

Hackherry .......... 93 Maclura, see Toxylon... 94

Halesia ............ 1:20

Hamamelis .......... 8 !!

Наw .............. 1.8

Haw, see Hawthorn..... (i:-

Hawthorn .......... $6_{2}^{2}$

Hemlock ........... 48

Hercule's Club, see Angelica-tree ........ 126

Hickory ............ 106

Hicoria ............ 106

Holly ............. 81

Honey-locust ......... Ts

Hop-hornbeam ....... 103

Hoptree .............. 3

Horse-chestnut ....... 83

Ilex ............. 81

Incense-cedar ..........;

Iron Oak, see Post Oak. Ion Ironwood, see Hop-hornbeam ............. 103

Judastree, see Redbud... 78 Juglans . . . . . . . . . . 109

Juneberry Magnolia ............ it

Maiden-hair-tree ....... 46

Malus ............... (it)

Maple ............. 84

Mockernut .......... 109

Morus ............ 94

Mountain-ash ........ 59

Mountain Iaurel, s e e Kalmia ........... 118

Mulberry ........... 94

Myrica ............ 110

Nannyberry, see Black Haw ........... 12:

Nyssa ............ 127

Oak ............... 96

Osage-orange ........ 94

Ostrya .............. 103

Oxydendrum …..... 119

Papaw ............. 56

Paper-mulberry ...... 95

Papyrius ............ 95

Paulownia .......... 124

Peach ............. 77 
Pear

Salix

Pecan ............... 107

Sapindus

Pepperidge, see Tupelo.. 127

Sassafras

Persea

Persimmon

Picea

Pignut 108

Pine

Pinus

Plañera

Planer tree

Plane tree

Platanus

Plum

Poison Elder, see Poison Sumac

Poplar

Poplar, Yellow, see Tuliptree

Populus

Prickly-ash

Prunus

Ptelea

Pyrus

Quercitron

Quercus

102

Quince

Redbud

Red Cedar, see Red Juniper

Red Elm, see Slippery Eln

Rhamnus

Rhododendron

Rhus

Robinia

Rock Elm, see Cork Elm Rock Maple, see Sugar Maple
Serviceberry, see Juneberry

Shadbush, see Juneberry.

Sheepberry

Silverbell

Smoke tree

Snowdrop-tree, see Silverbell

Soapberry

Soft Maple, see Silver Maple

Sorbus

Sour Gum, see Tupelo.. 127 Sorreltree

Sourwood, s e e Sorreltree

Spindletree ......... 81

Spruce ............. 47

Stafftree ........... 81

Staphylea ........... 8.?

Sumac ............ 88

Sweet-gum .......... 90

Sweetleaf .......... 120

Sycamore ........... 90

Symplocos .......... 120

Tamarack

Taxodium

Thorn, see Hawthorn... 62

Thuja ............ 52

Tilia .............. 58

Toxicodendron ....... 89

Toxylon ............. 94

80 Tree-of-heaven ....... th

$92 \quad$ Tsuga $\ldots \ldots \ldots \ldots \ldots \ldots$ 48

Tuliptree ........... 55

87 Tupelo ............. 127 
P.IGit:

P.IGi:

Ulmus ............91 White Maple, see Silver

Varnishtree .......... 83 Maple ............. 87

Viburnum ........... 128 Whitewood, see Linden. 5s Wahoo ............. 81 Willow ............ 113

Walnut ............ 109 Witch-hazel ........ 89

Water-beech, see Blue- Yellow Oak, see Chestbeech ........... 10? nut Oak ......... 99 Water Elm, see Planer- Yellow Poplar, see Tutree ............ $9: 3$ liptree ......... 5i

Wax-myrtle ........ 110 Yellow-wood ........ 79

White-cedar ......... 5? Zanthoxylum ........ 5i 




r 




19. $\int(196$

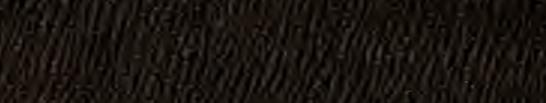

(1)

3)

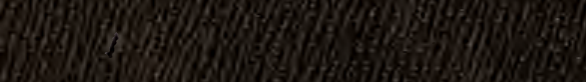

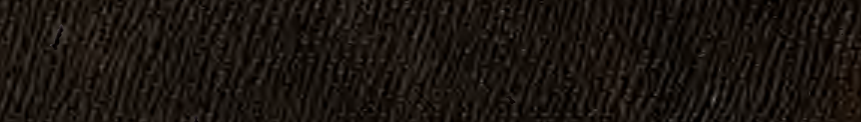

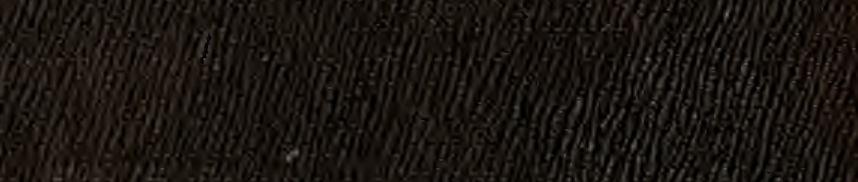

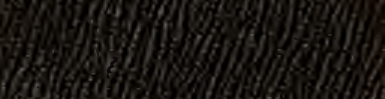
(1) (1) 19.

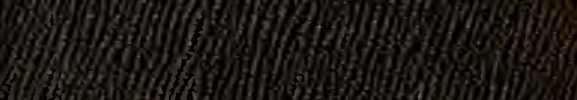
1.0.

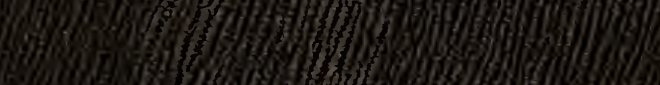
6.

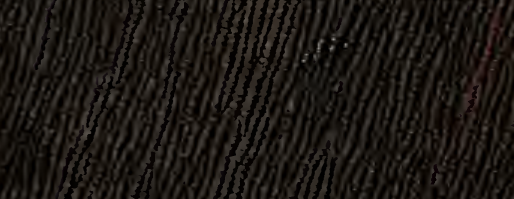

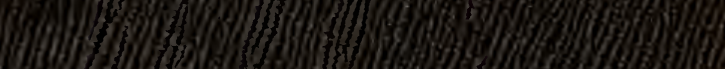

Hof (f) 9 fys 